\title{
2
}

\section{The Russo-Japanese War, World War I and the Washington Naval Conference}

\section{Towards the Commencement of the Russo-Japanese War}

\section{First Steps in the Diplomatic Service}

After passing the diplomatic service exam, in September 1896, Shidehara was posted to the Japanese consulate in Incheon, Korea, where he served as a consular assistant. ${ }^{1}$ Later, when the Russo-Japanese War erupted in February 1904, Shidehara was at the Busan consulate and even played a diplomatic role in the events that unfolded. After returning to Japan from Busan, he was appointed to roles such as the director of the Telegraph Division. Later, during and just after World War I, he assumed positions such as vice-minister for foreign affairs and ambassador to the US. His most important work at this time was his participation in the Washington Naval Conference as the plenipotentiary and ambassador to the US, which began in 1921 and stretched into the following year. During this period, therefore, Shidehara reached a position where the policies he enacted could potentially influence the direction of Japan's diplomatic efforts. This was also a time where he acquired the etiquette expected of a diplomat and developed his own principles. 
There are four topics that I wish to focus on while giving an overview of this quarter century. The first regards the formation of Shidehara's own thinking. What is particularly important here is his understanding of an 'open door policy'. It is said that, in general, Shidehara proactively adopted an American-style open door policy. Certainly, Shidehara did accept an open door approach as a guiding principle. On the other hand, it should be recalled that, at this time, Japan had 'special interests' in Manchuria in north-eastern China. These special interests in China would have been on Shidehara's mind. We should ask, therefore, how these different considerations or orientations came together in Shidehara's diplomatic outlook. Further, what did having an economic 'open door' really mean to Shidehara? To begin with, it should be noted that the term 'open door' itself is ambiguous. For the original 'open door notes' issued by the US, there were actually two meanings. It is necessary, therefore, to clarify the specific nuance that this term held for Shidehara.

To state the conclusion to this line of questioning in advance, while Shidehara was enthusiastic about adopting an 'open door' approach as a general principle, he also attempted to restrict its practical application. He utilised this concept in a restricted sense and thereby was able to find a compromise regarding Japan's 'special interests' in China. In this chapter, I will explain this accommodation in Shidehara's thinking through analysis of his response to matters such as the New Four-Power Consortium and the Washington Naval Conference. As I shall show, Shidehara's commitment to the principle of 'open door' economics did not simply mean an adoption of US policy. Rather, he was initially receptive to these ideas in the context of agreements such as the Anglo-Japanese Alliance (1902-23) and the Franco-Japanese Treaty (1907).

Meanwhile, Shidehara saw Japan's annexation of Korea in 1910 as a natural development. This might appear to run counter to the perception that he was internationally minded. One anecdote about Shidehara holds that he used to sit with a copy of Webster's Dictionary at hand and memorise Shakespeare. Such accounts might tempt us to think of Shidehara as cut from a different cloth than other Japanese diplomats. However, it should be remembered that this was only one side of the man. Shidehara fully identified with the mindset the Japanese people had at that time. Like them, he worshipped the imperial household, and he was a great admirer of Count Nogi Maresuke (1849-1912), the Imperial Japanese Army general who participated in the capture of Port Arthur from China in 1894 . 
Following the above consideration of the formation of Shidehara's own thinking, the second topic I wish to examine with respect to this 25 -year period is Shidehara's diplomatic style. Here, the impact of Henry Willard Denison—adviser to the Foreign Ministry when Shidehara was director of the Telegraph Division-was considerable. ${ }^{2}$ Up until his time at the Busan consulate, Shidehara showed no discomfort with the use of diplomacy backed up by the threat of military force. Indeed, he went as far as to support the launching of the Russo-Japanese War. However, his encounter with Denison would become a turning point. From then on, Shidehara would become a member of the committee for revising Japan's unequal treaties with Western powers and would also become highly familiar with matters of international law. However, even while Denison initiated him in the subtler arts of diplomacy, Shidehara was no passive recipient. A clearer view of Shidehara's approach is available by looking at how he handled the abrogation of the Anglo-Japanese Alliance at the Washington Naval Conference.

It is also important to situate the handling of public relations with respect to the topic of Shidehara's diplomatic style. ${ }^{3}$ Shidehara has been understood as having been largely indifferent to matters of public relations. His intense dislike of Japan's mass media emanates from the pages of his memoir, Gaikō 50 Nen (Fifty years of diplomacy). In reality, however, Shidehara also had his own form of public relations diplomacy. Here, too, the Washington Naval Conference provides an excellent opportunity for analysis.

The third topic that I will focus on for this period is Shidehara's personal relationships. As is well known, Shidehara and Katō Takaaki were brothers-in-law. Shidehara also had close relationships with individuals such as Komura Jutarō, Chinda Sutemi (1857-1929), Ishii Kikujirō (1866-1945) and Hara Takashi. Shidehara's personal connection with Komura is the most deserving of close attention. At first glance, it may seem as though Komura and Shidehara were polar opposites, given Komura's fierce promotion of continental policy aimed at Japan's domination of North-East Asia. However, Shidehara supported Komura in areas such as the revision of the unequal treaties and the annexation of Korea. This point will no doubt be instructive when comparing the Russo-Japanese War and the diplomacy of the 1920s. 
What was actually problematic for Shidehara was when his brother-in-law Katō, then foreign minister, drafted the Twenty-One Demands issued to China in 1915. I will also consider Shidehara's relations with diplomats such as Moroi Rokurō (1872-1940), Kawashima Nobutarō (1880-1957), Saburi Sadao, Honda Kumatarō, Hirota Kōki, Debuchi Katsuji, Tani Masayuki (1889-1962) and Ishii Itarō (1887-1954).

The final topic concerning this quarter century is how the various nations of the time viewed Shidehara's statements and actions. Naturally, diplomatic negotiations are important for our purposes here. However, the role of the diplomat is not restricted to negotiations alone. The acquaintances and relationships of trust a person has formed also reveal much about them. Because Shidehara's time as ambassador to the US marked the point at which his position rapidly strengthened, my examination of this topic will focus mainly on this period. In particular, though, Shidehara formed a number of relationships during his time as the plenipotentiary and ambassador to the US, around the time of the Washington Naval Conference. These include Shidehara's relationships with figures such as Secretary of State Charles Evans Hughes (1862-1948), Plenipotentiary Elihu Root and John Van Antwerp MacMurray (1881-1960), the chief of the State Department's Division of Far Eastern Affairs. I have explored these relations in a previous work. ${ }^{4}$

For this reason, I also wish to touch on some other more practical and specialised individuals with whom Shidehara interacted. These include Stanley Washburn, Root's secretary at the Washington Naval Conference; Roland S. Morris (1874-1920), the US ambassador to Japan; Norman H. Davis (1878-1944), undersecretary of state; DeWitt Clinton Poole, chief of the State Department's Division of Russian Affairs; Nelson Trusler Johnson, official at the State Department's Division of Far Eastern Affairs; Eugene H. Dooman (1890-1969), first secretary at the US embassy in Japan; and Edward Thomas Williams (1854-1944), chief of the State Department's Division of Far Eastern Affairs during World War I.

\section{The International Situation Following the First Sino-Japanese War}

In September 1896, Shidehara passed the fourth diplomatic service exam. Alongside Shidehara, the four individuals who passed included Koike Chōzō, who would later participate in the issuing of the Twenty-One Demands during his time as director-general of the Political Affairs 
Bureau. The following month, Shidehara was appointed consular assistant at Incheon, Korea. This was the first step of his initial diplomatic career, which would take him to locations such as London, Antwerp and Busan.

What was the international situation at that time? When Shidehara began his diplomatic career at the end of the nineteenth century, the reverberations of the 'Triple Intervention' still lingered. In 1895, when the Sino-Japanese peace treaty was signed at Shimonoseki, the three nations of Russia, France and Germany intervened. Although Japan was the supposed victor of the war, it was forced to return the Liaodong Peninsula to China. Naturally, the locus of East Asian international politics at this time was Korea. Following the conclusion of the First Sino-Japanese War, a series of influential figures served as Japan's ministers in Korea, including Inoue Kaoru, Komura Jutarō, Hara Takashi and Hayashi Gonsuke (1860-1939). While Incheon and Busan were not on the same level as Korea's capital Hanseong — then known in Japanese as 'Keijō' and today known as Seoul-they were nevertheless considered important. According to Hayashi Gonsuke, who served as consul at Incheon before the First Sino-Japanese War, 'even though it was the Incheon consulate, at the time it was akin to the consulate for the whole of Korea. ${ }^{5}$ It was surely no coincidence that Shidehara was sent to Incheon, given that he was expected to have a promising career.

When Shidehara arrived at his post in Incheon in January 1897, he earned the favour of the consul, Ishii Kikujirō. When Ishii finally transferred to Beijing, Shidehara assumed the role of the acting consul until the arrival of the new consul, Ijūin Hikokichi (1864-1924). Shidehara reflected that while Ijūin 'was not particularly skillful', he nevertheless 'possessed a certain kind of special magnetism that drew me to him'. ${ }^{6}$ While it may sound surprising, from his time in Incheon onwards, Shidehara was a heavy drinker. The branch chief of a local mercantile company with whom he was on good terms would often appear with high-quality Nadabrand spirits, whereupon Shidehara would close the door of his official residence, and together they would drink the night away. ${ }^{7}$

At that time, Japan was seeking to preserve its policy of Hokushu-Nanshin, literally 'defend the north and advance to the south'. At the same time, it was attempting to establish a position in Korea that would put it on an equal footing with Russia. In May 1896, a memorandum between Japan and Russia was signed in Hanseong by Komura and Karl Ivanovich Weber (1841-1910). In June of the same year, the Yamagata-Lobanov 
Agreement was signed in Moscow. The Komura-Weber Memorandum sought the return of the king of Korea, who had sought refuge in the Russian legation. The Yamagata-Lobanov Agreement stipulated that Japan and Russia would jointly provide assistance for Korea's public budget. The Komura-Weber Memorandum and the Yamagata-Lobanov Agreement were still of importance in 1901, when Shidehara returned to Korea to serve as consul in Busan. This was because they included a provision for the management of the telegraph lines between Hanseong and Busan that was advantageous to Japan. Further, the Nishi-Rosen Agreement, signed in Tokyo in 1898, recognised Korea's independence and declared that the respective parties would refrain from interfering in the internal politics of the country. Even Shidehara's memoirs feature an idyllic account of the Incheon of this period, with the warship captains of both nations sharing drinks. ${ }^{8}$

In May 1899, Shidehara was assigned to London. When he arrived at his post in August, he began to polish his English. The effort he put into this study would become an important asset in his future career. In December 1900, he was transferred once more, this time to the position of consul in Antwerp. Located in the north of Belgium, Antwerp was one of Europe's most important trading ports. However, not long afterward, in September 1901, Shidehara was ordered to return to Korea. This time, he assumed the office of consul in Busan. He remained in Busan until March 1904 and the beginning of the Russo-Japanese War. These events comprised Shidehara's formative experience as a diplomat.

During this period, Russia's foreign minister, Aleksei Borisovich Lobanov-Rostovskii, and its finance minister, Sergei Yulievich Witte, were making progress with their policies for containing Japan. In 1896, they signed a secret military alliance with the Chinese politician and general Li Hongzhang. On the basis of this pact between Russia and the Qing dynasty, work on the Chinese Eastern Railway began in 1898. The Chinese Eastern Railway would cross the length of Manchuria when completed. Another major incident at this time was the outbreak of the Yihetuan Movement (Boxer Rebellion) in China. The rebellion was suppressed in 1900 by a coalition army of eight nations, including Japan. In the following year, the European Great Powers, Komura Jutarō, and Li Hongzhang signed the Boxer Protocol. This agreement gave Japan reparations and the right to station troops in China. Regarding Komura Jutarō's performance at the Yihetuan Movement peace conference, Shidehara wrote: 'Komura-san's farsightedness was on display.' 


\section{Komura Jutarō and Hayashi Tadasu}

At that time, Komura Jutarō was the driving force in Japanese diplomacy. Komura successively filled the roles of ambassador to Korea, vice-minister for foreign affairs, ambassador to the US, ambassador to Russia and minister to China. In 1901, he became the foreign minister in the first Katsura Tarō cabinet.

The common view is that Japan at this time had two basic orientations or policies. ${ }^{10}$ First, Katō Takaaki and Komura Jutarō promoted ManKan Fukabun, the position that Japan's interests in Manchuria and Korea could not be dealt with separately but were intertwined. Second, Itō Hirobumi, Inoue Kaoru and a number of other figures promoted ManKan Kökan, the position that influence in Manchuria could be ceded to Russia in exchange for Japan having control over Korea. The first of these two positions favoured the obstruction of Russia's southward advance by strengthening Japan's relationship with the UK. The second promoted the formation of an entente between Japan and Russia. The first prevailed within Japan's diplomatic circles, and, as a result, negotiations towards an Anglo-Japanese alliance soon began.

The initial alliance was signed in January 1902. According to the first article of the Anglo-Japanese Alliance, both nations recognised each other's special interests in Qing-dynasty China, while the UK also recognised Japan's special interests in Korea. The second article stated that if either nation were to go to war, the other would maintain neutrality. The third article stated that if a third nation joined that conflict against the allied partner, the other partner would assist the ally. This was the birth of the defensive alliance.

It was Hayashi Tadasu who would directly experience from his postings the sequence of events that led from the Triple Intervention to the signing of the Anglo-Japanese Alliance. Hayashi's formative experience as a diplomat was the Triple Intervention of 1895 . It was Hayashi who, as vice-minister for foreign affairs, received the Triple Intervention memorandum from the ministers of Russia, Germany and France. ${ }^{11}$ On that occasion, Foreign Minister Mutsu Munemitsu had come down with tuberculosis and was receiving treatment in the town of Maiko, Hyogo Prefecture. ${ }^{12}$ Under the command of Foreign Minister Mutsu, Vice-Minister Hayashi, the director-general of the Political Affairs Bureau, Katō Takaaki, and the director-general of the International Trade Bureau, Hara Takashi, were 
jointly referred to as the 'Mutsu Triumvirate'. Originally the governor of Hyogo Prefecture, Hayashi was summoned to the Ministry of Foreign Affairs by the previous foreign minister, Enomoto Takeaki (1836-1908), before he was promoted further by Mutsu.

Hayashi, shocked by the Triple Intervention, went himself as the minister to China to sign the Liaodong Peninsula Return Agreement and conclude the negotiations for the Sino-Japanese Treaty of Commerce and Navigation. This treaty, signed in July 1896, was a typically unequal treaty. Hayashi also attended the First International Peace Conference at The Hague as minister to Russia. Hayashi would go on to become Japan's minister to the UK, negotiating with Foreign Secretary Henry Petty-Fitzmaurice, Lord Lansdowne, and signing the Anglo-Japanese Alliance. Of course, Hayashi was also critical of Itō Hirobumi's promotion of a Russo-Japanese entente. Later, in 1905, the Second Anglo-Japanese Alliance would also be signed by Hayashi and Petty-Fitzmaurice. ${ }^{13}$

Naturally, Shidehara was also critical of the Triple Intervention. As he put it, 'the Triple Intervention amounts to a diplomatic conspiracy', with the secret treaty signed between China and Russia 'exposed during the course of the Washington Naval Conference of 1922'. ${ }^{14}$ In Shidehara's view, it was necessary for Japan to 'endure the bitterness of the Triple Intervention, enduring hardship so that it might slowly develop its national power, and then within a decade push Russia out of south Manchuria. ${ }^{15} \mathrm{He}$ added that, 'in the end, trickery will not determine the fate of the nation's next hundred years'. ${ }^{16}$

\section{Towards the Beginning of the Russo-Japanese War}

Shidehara left for his new position as consul in Busan in October 1901. Busan and Japan have a historically significant connection. In the Edo period, Busan contained a Japanese trading settlement called Waegwan (Wakan in Japanese), which covered some 330 square kilometres. Waegwan's internal affairs were originally managed by the head of the Tsushima domain and functioned as a gateway to Korea, which at that time was ruled-like Japan — according to a policy of national isolation. ${ }^{17} \mathrm{With}$ the opening of ports following the Japan-Korea Treaty of 1876, Busan would come to play an increasingly important role in events between the two countries. It was not only foreign settlements and boards of trade that shaped it. Busan was also of strategic importance for transport. 
The year that Shidehara assumed this new posting saw the establishment of the Keifu Railway Company, with Shibusawa Eiichi (1840-1931) as the chairman. The Keifu Railway Company linked Hanseong and Busan together (the characters for 'Keifu' [京釜] mean 'Capital' and 'Busan') and opened at the height of the Russo-Japanese War. Meanwhile, the shipping company Nippon Yūsen had already expanded its sea routes to Busan and Incheon before the First Sino-Japanese War, concentrating its efforts on Korea. Nippon Yūsen had also acquired the coastal right of passage through Korean waters from the Korean government at the time of the First Sino-Japanese War. ${ }^{18}$ Following the end of the Russo-Japanese War, another shipping company, Sanyō Kisen, commenced services from Shimonoseki to Busan. Once the Shimonoseki-Busan line was connected to the Sanyō railway line and the Keifu railway line, it became possible to travel from Tokyo to Hanseong within 60 hours. ${ }^{19}$ Before long, the railway network of the Korean Peninsula was joined to the South Manchuria Railway, creating a main artery for operations on the continent. Alongside this development, Busan would develop into a major city, second in Korea only to Hanseong.

As it happened, as consul in Busan, Shidehara had an offer of marriage. His future wife, Masako, was the youngest of the four daughters of Iwasaki Yatarō (1835-1885). Iwasaki Yatarō was the founder of the Mitsubishi financial conglomerate (zaibatsu). In fact, Masako and Shidehara's relationship had already begun when Shidehara was stationed in London. They were married in Tokyo in January 1903. Their matchmaker (nakōdo) was Ishii Kikujirō, Shidehara's good acquaintance from his time in Incheon. Through his marriage with Masako, Shidehara become brother-in-law to Katō Takaaki. This was because Mrs Katō, Harumi, was the eldest daughter of Iwasaki Yatarō. ${ }^{20}$

Katō Takaaki would serve as Japan's foreign minister on several occasions: first in the fourth Itō cabinet and later in the first Saionji cabinet and the third Katsura cabinet. Each appointment, however, would last only a short time. It was his later service as foreign minister in the second Ōkuma cabinet that would put his name in the history books. In particular, the Twenty-One Demands he issued to China in 1915 are notorious. Eventually, Katō would come to lead the Kenseikai party, forming a government as prime minister in 1924. The foreign minister in this cabinet would be none other than Shidehara. ${ }^{21}$ In any case, after the wedding, Shidehara returned to his post at Busan. In the fall of 1903, his first son, Michitarō, was born. Yet Shidehara had no time to enjoy 
the life of a newlywed because the Russian situation was becoming more and more serious. Japan and Russia exchanged alternative propositions regarding Manchuria's territorial integrity and the neutral zone in Korea. As negotiations bogged down, Japan began preparing for war. It would finally come in February 1904.

Hostilities began when the Japanese navy fired upon a Russian fleet outside of the port of Lushun. At the same time, the Japanese army also began to mobilise, advancing northwards through the Korean Peninsula, defeating the Russian army in a battle at Liaoyang and capturing Lushun. In March 1905, the Japanese army secured a victory at the battle of Mukden (present-day Shenyang) and the navy won a sea battle in May. In September that year, a peace treaty was signed near Portsmouth, New Hampshire, mediated by the US. Shidehara was no mere spectator during the Russo-Japanese War; he had his own role to play.

It was 6 February 1904. Leaving for work early in the morning as usual, Shidehara saw an unusual sight as he surveyed the port of Busan from the consulate. A Japanese warship had captured a Russian steamship, the Mukden, belonging to the Chinese Eastern Railway Company. This incident would draw a note of protest from the Russian consulate. According to international law, capturing an enemy nation's vessel was illegal if it was encountered in the territorial waters of a neutral country. Shidehara, however, rejected Russia's protest, commenting: 'Given the current discontinuation of diplomatic relations between Japan and Russia, I am in no position to enter into negotiations with the Russian consulate, regardless of the circumstances'. ${ }^{22}$ Admittedly, this was quite an obstinate position for Shidehara to take. Certainly, war loomed in the atmosphere. The Katsura cabinet had cut off diplomatic relations on 4 February. However, it was not until two days after the capture of the steamship, on 8 February, that the Japanese navy would fire upon the Russian fleet at Lushun. The day after that, on 9 February, two Russian warships were sunk in a naval battle off the coast of Incheon. War was formally declared on 10 February. ${ }^{23}$

In fact, before the war began, Shidehara had received Foreign Minister Komura's permission to support the Japanese navy's occupation of the telegraph offices at Busan and Masan. As a result, the Russian consulate in Busan was unable to receive coded telegrams from its minister and was driven into a corner. Hayashi Gonsuke, Japan's minister to Korea based in Hanseong, also cooperated with Shidehara in closing down Russia's 
telegraph-based communication. ${ }^{24}$ On 23 February, Hayashi signed the Japan-Korea Protocol, permitting the free movement of Japanese troops within Korea's borders. This paved the way for the annexation of Korea through the three Japan-Korea agreements.

\section{Diplomacy in the Aftermath of the Russo-Japanese War}

\section{Shidehara's Encounter with Denison}

Shidehara was ordered to return to Japan in March 1904, following the commencement of the Russo-Japanese War. His next appointment would be to oversee the Telegraph Division. The Telegraph Division was in charge of the drafting and decoding of encrypted telegrams, as well as the sending and receiving of various other telegram messages. The then director of the Telegraph Division, Ishii Kikujirō, was also put in charge of the International Trade Bureau, leaving Shidehara as the de facto Telegraph Division director.

In November 1905 Shidehara was officially promoted to director. He would continue in this role for some time, even after becoming the director of the Investigation Division and the director-general of the Investigation Bureau. The Investigation Division was established to examine domestic and foreign laws, as well as international law. Shidehara would continue to hold these two offices concurrently until his assignment in 1912 as a counsellor to Japan's embassy in the US. ${ }^{25}$

At that time, the individual who would train Shidehara in the writing of diplomatic telegrams was Henry Willard Denison, then adviser to Japan's Foreign Ministry. Denison had originally stayed in Japan as the assistant to the US consul general, who was based in Yokohama. He was then hired as an adviser to Japan's Foreign Ministry on the recommendation of US minister John A. Bingham. Denison would remain employed in Tokyo as an adviser for the Foreign Ministry from 1880 until his death from illness in 1914. It was rumoured that Denison had memorised all of Japan's diplomatic precedents since the period of the Meiji Restoration. ${ }^{26}$ Shidehara's official residence was very close to Denison's lodgings. Almost every morning, Shidehara would take 30-40-minute walks with 
Denison around the area of the Imperial Palace, learning much from their conversations. Denison was also an astute judge of politicians. When the Katsura cabinet was formed in 1901, Denison was inwardly pleased. ${ }^{27}$

Shidehara was particularly impressed by Denison's anecdotes about littleknown episodes of diplomacy concerning the start of the Russo-Japanese War. According to Denison, in July 1903 Foreign Minister Komura ordered Denison to draft telegraphic instructions to be addressed to the Japanese minister in St Petersburg Kurino Shinichirō (1851-1937), which requested negotiations with Russia. For Komura, 'Russia’s aggressive actions in the Manchurian and Korean regions had recently reached the stage where they could no longer be overlooked'. When Denison suggested to Komura that the instructions include the statement that 'we must recognize the importance of avoiding war at all costs', Komura replied: 'I have been told that whether it ends in war shall be determined by the results of the negotiation'. As Denison told Shidehara, 'I could tell that the [Japanese] government was determined ... and so I was able to get right to work drafting the instructions' ${ }^{28}$

Shidehara was not satisfied with this account. He asked Denison whether the instructions should not differ depending on whether the government was determined to go to war. Denison replied that if the policy was to avoid war then threatening the other party could still be a valid strategy. If, however, one was determined to go to war, then it was better to use as temperate language as possible, so that after hostilities commenced, the diplomatic papers could be made public in order to gain international sympathy. According to Shidehara, actions such as making diplomatic papers public after hostilities commenced was now something that practically all the great powers have done in order to gain support for their positions'. ${ }^{29}$ It was also Denison who would teach Shidehara the various formats for writing such diplomatic papers as notes, verbal notes and memoranda. ${ }^{30}$

\section{The Treaty of Portsmouth - the Ceding of South Sakhalin and the Korean Provision}

The main theatre of the Russo-Japanese War was Manchuria, with Lushun and Mukden the scenes of hard-fought battles. There were no significant engagements in Korea. Around the time Shidehara returned to Japan from Busan, the Japanese navy was struggling to close off the entrance to Lushun harbor. Even after the Japanese army landed on the Liaodong 
Peninsula, it was not until January 1905 that they managed to defeat the Russian forces holding Lushun fort. Third Army Commander Nogi Maresuke directed the assault on Lushun. The Japanese army would also go on to occupy Mukden in March. However, its forces in the area were exhausted, preventing it from decisively defeating the Russian army. While the navy later secured a victory in the Sea of Japan in May, Japan nevertheless felt compelled to seek an early peace. It was then that US President Theodore Roosevelt stepped forward as a peace mediator. This was when Foreign Minister Komura travelled to the US.

Following peace negotiations with Russia, Japanese Foreign Minister Komura and Minister to the US Takahira Kogorō (1854-1926) signed a peace treaty to conclude the Russo-Japanese War. The treaty was signed on 5 September 1905, near Portsmouth, New Hampshire. On the Russian side, the representative empowered to sign the treaty was former finance minister Witte and then Ambassador to the US Roman Romanovich von Rozen (1847-1921). The instruments of ratification were exchanged on 25 November. The Treaty of Portsmouth included a number of important articles for Japan, including the recognition of Japan's hegemony over Korea (Article 2); the devolution of the leaseholds of the Chinese ports of Lushun and Dalian to Japan (Article 5); the transfer to Japan of the rights to the South Manchuria Railway (Article 6); and the ceding to Japan of the southern part of Sakhalin Island, below the 50th parallel north (Article 9). Further, according to the first of the additional conditions, Japan and Russia would recognise their respective rights in Manchuria to station 15 soldiers per kilometre of railway as guards. This led to Japan stationing two divisions of troops under the command of the governorgeneral of the territory of Kwantung. This would eventually become the Kwantung Army. However, Japan was not able to receive reparations from Russia.

With respect to Article 9 and the ceding of the southern part of Sakhalin, Shidehara hints at something. According to his memoirs, the day before the meeting of the Imperial Council in the second half of August, another meeting was held at the official residence of the lord president of the council. A number of government leaders attended, including the lord president of the council himself, Itō Hirobumi; Prime Minister Katsura Tarō; Navy Minister Yamamoto Gonbē (1852-1933); Army Minister Terauchi Masatake (1852-1919); and Vice-Minister for Foreign Affairs Chinda Sutemi (1857-1929). Shidehara served as secretary of the 
proceedings. According to Shidehara, when Yamamoto argued in favour of the demand that Russia cede part of Sakhalin, Itō directed Shidehara to put together the diplomatic instructions accordingly.

As it happened, when Chinda returned to the Ministry of Foreign Affairs after attending the Imperial Council the following day, he unexpectedly ordered Shidehara to send a telegram instructing the diplomatic staff to remove the request for reparations and the ceding of territory on Sakhalin. Shidehara had no choice but to send the telegram as Chinda instructed. Just afterwards, some good news arrived from the UK. Claude M. MacDonald, the British minister to Japan, informed International Trade Bureau Director-General Ishii that the Russian emperor was open to accepting the cession of southern Sakhalin. Acting on this information, Shidehara 'took personal responsibility' and sent a telegraph requesting that the execution of the previous instructions be delayed. ${ }^{31}$ After receiving this message, Komura made excuses in order to ask the Russian side to postpone the meeting. Prime Minister Katsura was then able to visit the Imperial Palace and receive permission to revise the previous instructions so that they would once more request that Japan demand the cession of southern Sakhalin. This was how Shidehara recalled these events.

If Shidehara's memory is correct, it would mean that his quick thinking in postponing the removal of the Sakhalin cession request allowed Japan to gain southern Sakhalin as territory. However, it is rather difficult to imagine Shidehara making such a request of his own accord, given that, at this time, he was only the surrogate director of the Telegraph Division. Rather, what is most important in this story is the role of International Trade Bureau Director-General Ishii. By relaying Russia's thinking as heard from MacDonald, he was able to propose to Prime Minister Katsura that Japan should not abandon its request for Sakhalin territory after all. Following his report to Vice-Minister for Foreign Affairs Chinda, Ishii had Shidehara send the telegram instructing that a demand be made for the ceding of southern Sakhalin. ${ }^{32}$ The then director-general of the Political Affairs Bureau, Yamaza Enjirō (1866-1914), who also travelled to the US with Komura, attributed the acquisition of southern Sakhalin to Komura's skill. ${ }^{33}$ However, while Yamaza was expected to succeed Komura and become foreign minister one day, this was not to be. In fact, Yamaza passed away suddenly in 1914 while he was Japan's minister to China. This was three years after Komura's death. 
Of course, the Treaty of Portsmouth included more than just the cession of southern Sakhalin. Article 2 included the following clause with respect to Korea:

The Imperial Russian Government, acknowledging that Japan possesses in Korea paramount political, military and economical interest, engages neither to obstruct nor interfere with measures for guidance, protection and control which the Imperial Government of Japan may find necessary to take in Korea. ${ }^{34}$

What did Shidehara think of this clause on Korea? In his own words, he wrote:

Because at the time, our government sought to root out the source of trouble in the Far East, and foresaw that this could well necessitate the step of annexing Korea, but knew that it would not be appropriate to state so explicitly in the text of the treaty, it was necessary to use more abstract language and request that Russia recognise Japan's right to give 'guidance, protection, and control' to Korea. ${ }^{35}$

In other words, the section of the clause noting Japan's right to take measures to give necessary 'guidance, protection, and control' can be understood as having been included with an eye towards a future annexation of Korea by Japan.

In fact, it was Denison who had instructed Shidehara in the use of such language. Denison had told Shidehara that:

It was a normal trend for measures to guide sooner or later becoming measures to protect, and for protection to sooner or later become an incentive for shifting towards control. ${ }^{36}$

In reality, Japan-Korea relations began with the Japan-Korea Protocol of February 1904, followed by three Japan-Korea agreements, and culminated in the conclusion of the Korea Annexation Treaty in August 1910. Watching over this process in the Ministry of Foreign Affairs, Shidehara thought that, 'at the time, his [Denison's] prediction in the case of Korea was coming true step by step. ${ }^{37}$ Shidehara also thought that the section in Article 2 of the Portsmouth Treaty on 'guidance, protection, and control' should be used in Article 3 of the Second Anglo-Japanese Alliance that was signed in August 1905. However, in the editing process, 
these terms were mistakenly transposed to read: 'guidance, control, and protection'. This error was not discovered until after the treaty was signed, much to Denison's regret. ${ }^{38}$

After signing the Treaty of Portsmouth, Komura suddenly fell ill and had to postpone his return to Japan. ${ }^{39}$ When he finally returned in October 1905, Shidehara went to Yokohama to greet him. When the party arrived at Shinbashi Station, Prime Minister Katsura and Navy Minister Yamamoto boarded the train and supported Komura by both arms to help him dismount. The public mood in Japan was volatile. Yet, as Shidehara put it, Katsura and Yamamoto felt that if they would die, they would die together with Komura'. ${ }^{40}$ What was on Shidehara's mind was the scene when Komura was dispatched to Portsmouth. At that time, crowds had come to cheer Komura as he departed as Japan's plenipotentiary representative. Komura, however, remained composed and whispered to Shidehara:

The crowd that cheers our party departing today may in the future turn against us and become a cursing, violent mob. At the very least, then, we should cheerfully accept this demonstration of good will while it lasts. ${ }^{41}$

In other words, according to Shidehara, even before journeying to the US, Komura anticipated that the peace treaty would be poorly received by the Japanese public. And indeed, at the end of September 1905, tens of thousands of demonstrators in Tokyo's Hibiya Park protested the perceived shortcomings of the Treaty of Portsmouth, such as the lack of reparations. Moreover, mobs rampaged through Tokyo, attacking and setting fire to locations such as the Kokumin Shimbun Company, the official residence of the home secretary, and numerous police stations. The riots, which lasted two days, led to the deaths of 17 people, with hundreds wounded. This was known as the Hibiya Incendiary Incident. The government responded with a declaration of martial law. At one point, even the Ministry of Foreign Affairs was surrounded by a mob. Shidehara watched the police fighting the rioters from the ministry windows. Shidehara was clearly sympathetic to Komura. This incident may well have been a catalyst for his own understanding of the proper distance to be kept from popular sentiment when it came to diplomacy. ${ }^{42}$ 


\section{Treaty Revision and Continental Policy- Supporting Komura Diplomacy}

While public opinion had turned against Komura, Japanese politics itself entered a period of stability. The leading party in the Diet, the Seiyūkai, supported the Katsura cabinet's peace policy. The Seiyūkai was formed in 1900 by figures such as Itō Hirobumi and Hoshi Tōru (1850-1901) of the Kenseitō party. At the time of the Treaty of Portsmouth, Saionji Kinmochi (1849-1940) was the president of the Seiyükai. However, the Seiyūkai's support of the peace treaty negotiated at Portsmouth came at a cost. In exchange, they received the promise that the Katsura cabinet would transfer administrative power to the Seiyūkai. Hara Takashi of the Seiyūkai conducted the manoeuvring to help secure this agreement. Hara had multiple meetings with Prime Minister Katsura during the course of the Russo-Japanese War. With the formation of the Saionji cabinet following the transfer of power, Hara himself was appointed minister of home affairs. ${ }^{43}$ This development indicated that the Seiyūkai was increasingly being recognised as a political party in the establishment by the older domain-based (Hanbatsu or Meiji oligarchy) cliques of figures such as Yamagata Aritomo.

Political power was subsequently passed from the first Saionji cabinet to the second Katsura cabinet, the second Saionji cabinet, and to the third Katsura cabinet. This state of affairs continued until 1913 and the collapse of the third Katsura cabinet. Today, this era is referred to as the 'Kei-En' (桂園) era. The term 'Kei-En' combines the character for Katsura (桂) and the middle character of Saionji (西園寺). With the formation of the first Saionji cabinet in January 1906, Katō Takaaki, and later Hayashi Tadasu, became foreign minister. Nevertheless, Shidehara and Komura's relationship continued. When the second Katsura cabinet was formed in July 1908, Komura returned to the post of foreign minister. As director of the Investigation Division, Shidehara had been ordered to participate in the Treaty Revision Preparatory Committee. He would now play a role in supporting both the treaty revision and the continental policy advocated by Komura.

In October 1908, Foreign Minister Komura officially announced the formation of the Treaty Revision Preparatory Committee. Assuming the role of committee chairmen, Komura nominated Minister of Home Affairs Hirata Tosuke, Minister for Agriculture and Forestry Ōura Kanetake 
and Former Ambassador to Germany Inoue Katsunosuke (1861-1929) as vice-chairmen. From the Ministry of Foreign Affairs, Vice-Minister Ishii Kikujirō, Political Affairs Bureau Director-General Kurachi Tetsukichi (1871-1944), International Trade Bureau Director-General Hagiwara Shuichi (1868-1911), Counsellor to the Chinese Legation Abe Moritarō, Investigation Division Director Shidehara and Secretary Moroi Rokurō were appointed as committee members. The committee also contained a number of individuals from outside of the Ministry of Foreign Affairs, including Cabinet Legislation Bureau Director-General Yasuhiro Tomoichirō (1859-1951), Vice-Minister of Home Affairs Ichiki Kitokurō (1867-1944), Vice-Minister of Finance Wakatsuki Reijirō, and Secretary for the Ministry of Agriculture and Commerce Tsurumi Sakio (1873-1946).

Some readers may be puzzled at the participation of Finance Ministry bureaucrats in the process of treaty revision. However, this is not unnatural. Treaty revision has a significant impact on internal affairs. If, for example, Japan could succeed in restoring its own customs autonomy, then this would be of great interest to the Finance Ministry. This is why Prime Minister Katsura took the unusual step of also assuming the role of finance minister and assisting Foreign Minister Komura's initiative. Komura also nominated Vice-Minister of Finance Wakatsuki as the chairman of the special committee on general tariffs. For the chiefs of the special committees on conventional tariffs, land ownership and perpetual leases, he appointed Ishii, Yasuhiro and Ichiki, respectively. International Trade Bureau Director-General Hagiwara Shuichi, who was personally selected for this role by Hayashi Tadasu, was also engaged in revitalising trade with China while he was engaged in the work of treaty revision. ${ }^{44}$

Shidehara's role on the committee was to examine the issues of perpetual leases and land ownership rights for foreigners. He was also responsible for liaising with Denison. Under Shidehara, investigations were pursued by Moroi Rokurō, Kawashima Nobutarō and Itō Nobufumi. ${ }^{45}$ Shidehara had a particularly close relationship with Moroi. Previously, Moroi had succeeded Shidehara's old posting in London and Antwerp. According to diplomat Kimura Eiichi, Moroi studied economics assiduously while assigned to the consular post in Antwerp. This diligence served him well after he returned to Japan, with Moroi becoming the manager of the Treaty Revision Preparatory Committee. Later in his life, Shidehara 
would propose a memorial for Moroi and sign the condolence book. Sitting with his desk alongside Moroi was Kawashima Nobutarō. Kawashima's presence was heartening for Shidehara, given his familiarity with international trade policy. In February 1911, with the conclusion of agreements such as the new Japan-US Commerce and Navigation Treaty, Japan regained its tariff autonomy. ${ }^{46}$

Other diplomatic issues included Japan's relationship with Korea. However, this issue would also gradually be resolved, as Japan received consent from the other world powers to turn Korea into a protectorate. In October 1909, the moderate-faction member and lord president of the council, Itō Hirobumi, was assassinated in Harbin by An Chunggun, a member of the Korean independence movement. This incident had the effect of accelerating the annexation of Korea the following year. With this development, the locus of international politics in the region shifted from Korea to Manchuria. As noted above, Shidehara understood the clause on Korea in the Treaty of Portsmouth as already anticipating the future annexation of Korea. As Shidehara wrote:

Our government has recognized that in order to reform the administration of Korea and establish peace in the Far East, it is necessary to take the decisive action of annexing Korea. Therefore, in August in 1910, the governments of both nations concluded the treaty of annexation. ${ }^{47}$

In other words, he saw the annexation of Korea as a natural outcome. In Shidehara's mind, internationalism and imperialism coexisted.

This view of foreign relations was hardly unique to Shidehara. For example, Kurachi Tetsukichi, who had previously served as private secretary to Itō Hirobumi when he was resident general in Korea, has left similar comments in his own written recollections of the time. According to Kurachi, when he was made director-general of the Ministry of Foreign Affairs' Political Affairs Bureau, under Foreign Minister Komura, Komura ordered the drafting of a basic policy with respect to Korean annexation. On the basis of this draft, the cabinet meeting of July 1909 decided to move ahead with Korean annexation when the appropriate time arose. Ishii Kikujirō reflected similarly that 'the annexation of Korea was absolutely unavoidable for the sake of establishing a general peace in the East'. ${ }^{48}$ 
Upon annexing Korea, the Japanese government announced that it would impose tariffs for a 10 -year period. Nevertheless, it was not long before Japan removed the import duty on Korean rice. According to Kawashima Nobutarō, this was Shidehara's decision. In June 1911, Shidehara received a set of gold cups for his role in the annexation of Korea. Later, as viceminister for foreign affairs, he naturally displayed no particular reaction when the Ministry of Home Affairs reported the imprisonment and other sentences against Korean independence activists. ${ }^{49}$ When Komura's second term as foreign minister ended in July 1911, Shidehara was ordered to serve as director-general of the newly formed Investigation Bureau. Then-diplomat (and future prime minister) Ashida Hitoshi (1887-1959) would later reflect that 'at that time the Investigation Bureau was a new bureau that carried out the roles of today's Research Bureau and Treaties and Conventions Bureau'..$^{50}$

Komura, who pursued a shrewd continental policy, is often considered to have had a style antithetical to Shidehara's, who was generally very rationalistic. Certainly, for their respective periods as foreign minister, this framing of their differences is understandable. From among the diplomats of that period, Honda Kumatarōs trajectory is instructive here. Previously, Honda had accompanied Foreign Minister Komura as a private secretary for the signing of the Treaty of Portsmouth. He deeply admired Komura. $\mathrm{He}$ would later be at the forefront of those criticising Shidehara's own diplomatic efforts and would assume the position of ambassador to China under the Wang Jingwei regime in $1940 .{ }^{51}$ That said, it is not true that Shidehara was antagonistic towards Foreign Minister Komura. In fact, Shidehara lent Komura practical support. It must be added that Shidehara had his own critics within the department. According to Mushanokōji Kintomo (1882-1962), a group based in the Political Affairs Bureau, including Ariyoshi Akira, Yoshizawa Kenkichi (1874-1965), Hirota Kōki and Matsuoka Yōsuke (1880-1946), together with Nakamura Takashi of the International Trade Bureau and Honda Kumatarō of the secretary office, 'formed an increasingly passionate anti-Shidehara clique. ${ }^{52}$ In his view, their opposition to Shidehara was rooted in envy at his success. 
Table 1: Prime ministers and foreign ministers, 1900-21

\begin{tabular}{|l|l|}
\hline Prime Minister & Foreign Minister \\
\hline Itō Hirobumi (1900-01) & Katō Takaaki \\
\hline Katsura Tarō (1901-06) & Komura Jutarō \\
\hline Saionji Kinmochi (1906-08) & $\begin{array}{l}\text { Katō Takaaki } \\
\text { Hayashi Tadasu }\end{array}$ \\
\hline Katsura Tarō (1908-11) & Komura Jutarō \\
\hline Saionji Kinmochi (1911-12) & Uchida Yasuya \\
\hline Katsura Tarō (1912-13) & Katō Takaaki \\
\hline Yamamoto Gonbē (1913-14) & Makino Nobuaki \\
\hline Ōkuma Shigenobu (1914-16) & $\begin{array}{l}\text { Katō Takaaki } \\
\text { Ishii Kikujirō }\end{array}$ \\
\hline Terauchi Masatake (1916-18) & $\begin{array}{l}\text { Terauchi Masatake (temporary concurrent) } \\
\text { Motono Ichirō } \\
\text { Gotō Shinpei }\end{array}$ \\
\hline Hara Takashi (1918-21) & Uchida Yasuya \\
\hline
\end{tabular}

Note: With the exception of the period of the Terauchi cabinet, I have omitted temporary periods during which the prime ministers also took on the role of foreign minister.

\section{Japan-US Relations and the End of the Meiji Era}

\section{Denison's Will}

In May 1912, Shidehara was transferred from director-general of the Investigation Bureau to the role of counsellor at the Japanese embassy in the US. At this time, Denison was going to the US for a vacation. Shidehara decided to travel with Denison as far as Washington, DC, and the two began preparing for their departure simultaneously.

When helping to clean out Denison's drawers in the office, he found several drafts of telegrams addressed to Minister Kurino, who worked under Foreign Minister Komura, relating to diplomacy surrounding the start of the Russo-Japanese War. Each of the telegram drafts was written in Denison's hand, and they amounted to 14 or 15 revisions of a single message. For Shidehara, 'those drafts amounted to a perfect model for studying the writing of diplomatic papers, while also being valuable historical documents for understanding Japan's diplomatic efforts'. ${ }^{53}$ 
For this reason, Shidehara asked if he could keep the drafts. Denison, after thinking it over for a moment, suddenly threw the documents into the fireplace and burned them.

Denison turned to a dumbfounded Shidehara and calmly explained. He had burned the documents because others might have the wrong impression after reading them. The success of the diplomacy surrounding the commencement of the Russo-Japanese War belonged to Foreign Minister Komura. However, these documents could be misread as indicating that Denison had masterminded the Russo-Japanese negotiations behind the scenes. Shidehara was greatly moved by Denison's words. Denison felt that the publicly released diplomatic documents of the Japanese government had helped improve Japan's international image. For Shidehara, Denison's consideration in this regard 'impressed upon me greatly the extent of his good character, such that I was struck silent'. ${ }^{54}$

There was another reason in the back of Denison's mind, however. He was 66, had served the Ministry of Foreign Affairs for over 30 years and was considering retirement. Shidehara had no way of knowing it, but Denison felt that he did not have much longer to live. Thus, in July 1912, he prepared his will. He bequeathed his golden cups, granted by the emperor, to Ishii Kikujirō. Moreover, he left his entire personal library, of which he was quite proud, to Shidehara. Denison kept the writing of his will a close secret, never mentioning it to Shidehara. This was the last thing he did for Shidehara, who had admired and followed him so earnestly. However, because of Denison's official duties, he was unable to depart for the US on the same boat as Shidehara. This would be their final parting, as Denison died less than two years later. ${ }^{55}$

\section{The End of the Meiji Era-a Favourite Book: Nogi}

At the end of July 1912, just before his visit to the US, Shidehara learned of the death of the charismatic Meiji emperor. When Shidehara arrived in Washington in mid-September, he learned of yet another shocking occurrence: the suicide of Nogi Maresuke and his wife following the funeral of the Meiji emperor (an old samurai practice known as junshi). Nogi had been to the frontline during the Russo-Japanese War as Third Army commander, and deeds such as his supervision of the capture of Lushun were still fresh in Shidehara's memory. In 1907 Nogi became the president of Gakushūin School and oversaw the education of young 
Prince Hirohito. The suicide of Nogi, who had directed fighting in the Russo-Japanese War, seemed to symbolise the end of the Meiji era. As an entire era ended, hardly a soul in Japan was not deeply touched. ${ }^{56}$

Yet it was not only the Japanese who were shocked to hear of Nogi's suicide. One foreigner who was deeply affected by it was US journalist Stanley Washburn. Washburn had been attached to the Japanese army during the Russo-Japanese War as a freshly minted foreign correspondent. Nogi left a deep impression on young Washburn in that period. Upon hearing of Nogi's suicide, Washburn quickly began writing down his memories of Nogi. He completed a manuscript in English for a book that would simply be titled Nogi, recounting incidents such as the capture of Lushun and Mukden by the Third Army, under Nogi's command. Washburn's Nogi was published in New York in February 1913. The work depicted Nogi as a brave figure who remained resolute even in the face of his own son's death in battle. It could even be considered an elegy. ${ }^{57}$

There was one Japanese reader who deeply enjoyed reading Nogi, recommending its Japanese translation to his friends. That was Shidehara, then counsellor to the Japanese embassy in the US. How Shidehara came to read this book is quite interesting. One day in 1913, when Shidehara was visiting the US State Department, a surprise gift was waiting for him. A temporary employee at the State Department, Hamilton Wright, had given Shidehara a copy of Nogi, which had been written by his brother-inlaw. Shidehara later stated that he 'devoured the whole thing all at once' and 'never tired of reading it'. ${ }^{8}$ His own copy of Nogi, however, became misplaced at some point while on loan to one of his friends.

Several years later, Shidehara had the opportunity to meet with Washburn while serving as ambassador to the US. When participating in the Washington Naval Conference as Japan's ambassador plenipotentiary, Washburn was working behind the scenes as secretary to plenipotentiary representative Root. The member of the Japanese side who dealt with Washburn most directly was not Shidehara but plenipotentiary representative Hanihara Masanao. Shidehara was able to make contact with Root starting from before the conference. ${ }^{59}$

On his impression of Washburn, Shidehara wrote:

His genius extended beyond the literary world. Both his ideals and his insight were remarkable. I realized that it was no coincidence that he came to admire General Nogi from his daily contact with that man. ${ }^{60}$ 
At that time Washburn presented Shidehara with a newly revised edition of Nogi. Shidehara 'kept that book beside him at all times, and after returning to Japan, showed it to his old schoolmate Mr. Meguro Masumi'. ${ }^{61}$

According to Meguro, Shidehara 'suggested that I try reading this book. He believed that young adults and students of our nation would benefit from it and that I too would surely find myself moved'. ${ }^{62}$ After receiving permission from his publishing company to have the book translated, Washburn informed Shidehara via Hanihara, the then ambassador to the US. This is how Washburn's Nogi came to be translated into Japanese by Meguro and published in 1924. Shidehara himself supplied the foreword, which stated:

In recent years there are many in our nation who are quite unreasonably infatuated with the latest ideas from abroad. Yet in foreign countries there are actually more than a few individuals who can interpret, understand, and respect the mind of one such as General Nogi, that model of the Japanese samurai of old ... Nogi examines the tendencies of the minds of us modern people. It is a particularly fascinating work. ${ }^{63}$

Although Shidehara tends to be interpreted as an unemotional rationalist, he venerated Nogi's idealism. Shidehara and Washburn's relationship would continue until his second term as foreign minister.

\section{The 1913 Alien Land Law}

In the fall of 1912, Shidehara assumed the position of counsellor at the Japanese embassy in the US. What was the relationship between Japan and the US like at that time? To answer this question, I would like to return briefly to the period of transition represented by the Russo-Japanese War. Japan's victory over Russia in that conflict inevitably influenced the JapanUS relationship. When a developing nation seeks a bigger role on the world stage, it cannot help but attract more critical attention. As Japan's world prominence grew, some in the US sought to exclude Japanese immigrants. At the root of this was prejudice against Asians. In 1906, San Francisco passed a resolution that segregated Japanese schoolchildren. Meanwhile, the state legislature of California attempted to prohibit Japanese people from owning land, but this move was prevented by Republican President Theodore Roosevelt and William Howard Taft. 
However, a turning point came under Democratic President Woodrow Wilson. Two alien land laws were passed in California. With the 1913 Alien Land Law, foreigners who were unable to naturalise as US citizens were forbidden from owning land. Despite the Japan-US Gentlemen's Agreement of 1908-which saw Japan voluntarily restrict the number of immigrants to the US - this law was clearly targeted at Japanese immigrants. Then the 1920 Alien Land Law prohibited even the leasing of land.

Japan did not simply remain silent when these laws were enacted. In fact, Shidehara was deeply involved in the reactions to both-as embassy counsellor in the case of the first law, and as ambassador to the US in the case of the second. Who were some of the key individuals staffing the Japanese embassy when the 1913 Alien Land Law was presented to the state legislature of California? Alongside then counsellor Shidehara was Ambassador Chinda Sutemi and Second Secretary Okabe Saburō, Third Secretary Ōta Tamekichi (1880-1956), Third Secretary Kawashima Nobutarō, Probationary Diplomat Okabe Nagakage (1884-1970), Probationary Diplomat Hiroshi Saitō and Embassy Clerk Imai Tadanao. ${ }^{64}$

Naturally, Ambassador Chinda and his colleagues protested the enactment of this law. President Wilson also dispatched Secretary of State William J. Bryan to California. However, they were not able to change the minds of the members of the state legislature. Nevertheless, Shidehara admired Ambassador Chinda and his willingness to engage Bryan in debate. Of Chinda, he wrote: 'His arguments were always perfectly reasonable, devoid of any disorder or anger, and expressed in inoffensive language. Yet the will he thereby expressed was extremely firm'. ${ }^{65}$ Shidehara also thought of Chinda as a master of the English language. Conversely, Shidehara was much harsher in his assessment of Bryan, whom he considered an eloquent yet inexperienced diplomat, unaccustomed to writing official documents. This evaluation was very typical of Shidehara.

The Republican Party held the majority in California's state legislature. If the Wilson administration could not convince them, nothing could be done. Even after Shidehara left the US, Chinda remained as the ambassador. He continued his negotiations with Bryan in an effort to prevent the establishment of similar laws in other states. Meanwhile, with the coming of World War I, the Wilson administration began to have doubts about Japan's opportunistic politics with respect to China. ${ }^{66}$ 


\section{The Influence of Ambassador Bryce}

Shidehara's tenure as counsellor at the Japanese embassy in the US would last only a year and two months. Nevertheless, it was long enough for him to be influenced by James Bryce, a British historian and then ambassador to the US. Bryce was already in his mid-70s, yet he took the time while he was ambassador to the US to revise his 1888 work, The American Commonwealth, for which he was well known in the country. ${ }^{67}$

What left a particular impression upon Shidehara was how Bryce deliberately refrained from challenging the Panama Canal Passage Tax Bill as it made its way through the US Senate. This Bill was disadvantageous to the UK, yet Bryce foresaw that the US would eventually come to regret it. For the same reason, Bryce admonished Shidehara for persisting in his protests against the Alien Land Law. According to British Foreign Secretary Sir Edward Grey: 'At Washington the personal position of Mr. Bryce was less that of an Ambassador than of a distinguished man of letters and knowledge'. ${ }^{68}$ With respect to the Panama Canal, Grey also seemed to have anticipated that sooner or later, the US would come to observe the agreements existing between the two nations and abolish the discriminatory canal passage tax.

According to the recollections of Öta Tamekichi, then third secretary at the Japanese embassy in the US, Shidehara was also instructed about diplomatic affairs by individuals such as the counsellor at the British embassy. Upon hearing that 'the British do not have the practice of pushing their own countrymen to one side', Shidehara decided not to press strongly for the right of Japanese to naturalise as Americans. ${ }^{69}$ In November 1913, Shidehara was relieved of his posting as embassy counsellor and ordered to a new posting in the UK. After spending time in a number of roles, including that of vice-minister for foreign affairs, he eventually returned to the US in November 1919, this time as Japan's ambassador.

In 1921, in Washington, Shidehara met Bryce again for the first time in several years. At this time Bryce was untitled. Shidehara took the opportunity to remark, somewhat wryly, that while the Panama Canal Passage Tax had been abolished, to the UK's benefit, the US's anti-Japanese laws did not appear to be going anywhere. Upon hearing this, Bryce glared at Shidehara, admonishing him once more not to be too 
eager for success. 'Do you not recognize', he asked, 'that the fate of nations is timeless?'70 Shidehara understood Bryce to mean that it was important to be prudent and avoid excessive appeals, entrusting developments to the US's own reform efforts. As it happened, Bryce was visiting the US to give a series of lectures. The topic of those lectures was international relations, and, while cautious, they called for coexistence with what was then called the 'colored races' of the world. ${ }^{71}$ Bryce would pass away the following year, making this exchange the last with Shidehara. It may also have been, I suggest, an exchange that Shidehara slightly misunderstood. In other words, Bryce's point was surely not to promote a straightforward attitude of forbearance.

\section{Grey's Enlightenment, News of Denison's Death - Counsellor to Japan's Embassy in the UK}

In December 1913, Shidehara arrived in London to assume his role as embassy counsellor. It had been 13 years since he was last in that country. By that point, the relationship between Japan and the UK had already begun to come under strain. The cause was Japan's railway policy in the Yangtze Valley. ${ }^{72}$ The ambassador to the UK at that time was Inoue Katsunosuke. Other embassy staff included Second Secretary Yoshida Isaburō, Third Secretary Sawada Setsuzō, Third Secretary Okabe Nagakage and Probationary Diplomat Yano Makoto.

After being influenced by Bryce in the US, Shidehara was now positioned to be influenced even further by British-style diplomacy. In this case, the instructor was none other than Secretary of State for Foreign Affairs Sir Edward Grey. Although Shidehara stayed in London for only half a year, Grey's thinking had a profound impact. It would not be an exaggeration to say that, for Shidehara, Grey came to represent the ideal foreign secretary. Grey served as foreign secretary for over a decade, from 1905 until 1916. Thus, when Shidehara arrived in the UK, Grey had already been at that post for eight years.

What particularly impressed Shidehara was Grey's response to the murder of a British citizen in Mexico. Initially, the UK wanted to send a warship to the region. The US, however, adopting the viewpoint of the Monroe Doctrine-which held that the US and Europe should each refrain from intervening in the other's sphere of influence-was opposed to this action. In response, Foreign Secretary Grey decided not to take 
any special action. The newspapers, rather than merely avoiding any criticism of Grey for this decision, actually praised him for preventing any worsening of the US-UK relationship. Shidehara was also surprised at the maturity of public opinion in the UK. He wrote: 'As can be seen from this one example, the average British citizen possesses a surprising degree of common sense, to an extent that would be unimaginable in Japan'. ${ }^{73}$ Grey's influence also manifested in Shidehara's integrity as a politician and his aversion to deciphering coded messages.

Shidehara was not the only foreigner to be influenced by Grey. Another such individual was US diplomat William Phillips (1878-1968). Phillips was assigned the role of first secretary at the US embassy in the UK at practically the same time that Shidehara received his assignment. Phillips, who would soon become undersecretary of state, met Grey again in Washington after the conclusion of World War I. At that time, Grey was tasked with improving relations between the UK and the US, as ambassador to the US. Unfortunately, Grey's eyesight began to weaken starting in World War I and worsened during his time in the US. Phillips could only watch in despair as Grey became blind. Shidehara too must have been upset by this development when he became ambassador to the US in 1919. When he met Grey in Washington, the man's eyes were already clouded over. The one consolation was that Grey remembered the high-pitched sound of Shidehara's English. ${ }^{74}$

In July 1914, Shidehara-then still a counsellor at the embassy in the UK-received some distressing news. Denison had died of illness in Tokyo. Upon learning of Denison's death, Shidehara sank into a deep grief. Alongside the passing of the Meiji emperor and the suicide of Nogi and his wife, the loss of Denison truly impressed upon Shidehara that an era had come to an end. Yet Shidehara had to compose himself and search for a successor to Denison. In this task he was assisted by Second Secretary Yoshida Isaburō. Eventually it was decided that Denison's replacement as adviser to the Foreign Ministry would be Thomas Baty, the famed English expert in international law. Following his appointment, Baty, too, would go on to live out the rest of his life in Japan..$^{75}$ 


\section{World War I}

\section{Ultimatums and the Outbreak of War-Dual Minister to the Netherlands and Denmark}

On the eve of World War I, Shidehara's career reached a significant turning point. This was his appointment as dual minister to the Netherlands and Denmark. Becoming an extraordinary and minister plenipotentiary meant a significant increase in responsibility. Previous occupants of this position included talented individuals such as Chinda Sutemi and Satō Aimaro (1857-1934). Chinda went on to receive a series of promotions, taking positions such as minister to Russia, vice-minister for foreign affairs, ambassador to Germany, ambassador to the US and ambassador to the UK. Satō, meanwhile, became Japan's ambassador to Austria-Hungary for the period leading up to World War I, before becoming ambassador to the US during the course of the war.

Shidehara was appointed dual minister to the Netherlands and Denmark in June 1914. Soon afterwards, on 28 June, gunshots rang out in Sarajevo, Bosnia. The presumptive heir to the Austro-Hungarian Empire, Franz Ferdinand, and his wife were assassinated by a young Serbian nationalist. The following month, when Shidehara arrived at his post in The Hague, World War I had already commenced. Meeting Shidehara at the Dutch legation was Second Secretary Matsuhara Katsuo, Probationary Diplomat Yokota Seiichirō and Legation Clerk Tokita Takurō.

In August, Japan declared war with Germany on the basis of the AngloJapanese Alliance. It was here that Shidehara had a bitter experience. Tasked with delivering Japan's ultimatum to Germany, Shidehara attempted to do so via Germany's minister to the Netherlands, with whom he was already familiar. This attempt was a failure. ${ }^{76}$ Funakoshi Mitsunojō (1867-1942), who was serving as counsellor at the Japanese embassy in Germany, has left us some comments regarding this ultimatum to Germany. According to Funakoshi, the first to make contact regarding the ultimatum was Foreign Minister Katō, followed by the ambassador to Italy, Hayashi Gonsuke and the minister to Sweden, Uchida Sadatsuchi (1865-1942). To make sure that the ultimatum was delivered properly, Katō contacted not only Uchida in Stockholm but also Shidehara in The Hague. As Funakoshi wrote: '[Katō] sent a classified telegram, telling us that he was sending the ultimatum, and that we needed to prepare to deploy a secret messenger. ${ }^{77}$ 
Upon receiving this message, Uchida judged that it would be difficult to send a secret messenger to Germany, given the tense circumstances. He therefore decided to reach out to a friend, the Brazilian minister to Sweden, requesting that he get in contact with the envoy in Brazil to arrange a coded telegram to be sent to Funakoshi in Germany. By the time Uchida's coded telegram reached Germany, however, Funakoshi had already received word of the ultimatum from Tokyo directly. Nevertheless, Funakoshi was deeply impressed by Uchida's resourcefulness. By contrast, Funakoshi was irritated by Shidehara, whom he perceived as dull-witted.

Leaving Germany, Funakoshi met with Shidehara in The Hague on his way back to Japan. Shidehara told Funakoshi that he had sent a telegram to Foreign Minister Katō, stating that he was unable to dispatch a secret messenger to Germany. According to Funakoshi, Shidehara apologised and said 'there was nothing else he could do'. Later in life, Funakoshi would remark: 'It is at times like these that you get to know a person's real merits' ${ }^{78}$ In any case, Foreign Minister Katō’s preparations for the ultimatum to Germany were exhaustive. Even the Japanese embassy in Germany was surprised at how he ensured the ultimatum's delivery by sending it through multiple routes. ${ }^{79}$

In fact, in terms of its exhaustiveness, Foreign Minister Katō's ultimatum to Germany stood in contrast to his Twenty-One Demands issued to China. These demands were thrust at China by Japan in January 1915. Among other things, they required that Japan inherit Germany's interests in Shandong, and also that Japan's leaseholds over Lushun and Dalian, as well as its control over the South Manchuria Railway, be extended for a period of 99 years. Japan used an ultimatum in order to force China to accept the key demands. Shidehara, who was then residing in the Netherlands, was not at that time very familiar with the process by which the demands were formulated. Nevertheless, upon learning of the details of their contents, Shidehara submitted a detailed opposing opinion to Katō. ${ }^{80}$

On the above topic, Shidehara's subordinate, Probationary Diplomat Tani Masayuki, left some remarks. According to Tani, after serious consideration, Shidehara resolutely relayed his opposing opinion on the Twenty-One Demands to Katō. Just as Denison once did with him, Shidehara frequently took Tani out for meals and walks. Vice-Minister for Foreign Affairs Matsui Keishirō also mentioned Denison's absence as one of the causes of the disorder surrounding the issuing of the Twenty-One Demands. Shidehara presumably held the same opinion. ${ }^{81}$ 
Recalling his time in the Netherlands later in life, Shidehara mentioned China's minister to Belgium, Wang Rongbao. As Shidehara told it, given that China was not yet a belligerent in World War I, Wang was free to assist Kimura Eiichi, then secretary at the Japanese legation in Belgium, to wind up his own affairs. Shidehara was not yet acquainted with Wang; however, Wang would come to spend most of the 1920s as Chinese minister to Japan. In the course of that decade, they would come to develop a candid relationship. Shidehara also had the opportunity to observe Kimura Eiichi, whom he considered to be 'brilliant' at his work. ${ }^{82}$

\section{Vice-Minister for Foreign Affairs - Concern for the Russo-Japanese Relationship}

Under the second Ōkuma cabinet, Ishii Kikujirō was appointed foreign minister, succeeding Katō, who had stumbled with his issuing of the Twenty-One Demands. Ishii would summon Shidehara to come and work with him in the role of vice-minister for foreign affairs. When Shidehara departed Europe in September 1915, the tide of war still favoured Germany and Austria. When the war broke out, no one could foresee that it would drag on for four years. In October, Shidehara arrived back in Japan from the Netherlands and assumed his new appointment as vice-minister for foreign affairs.

The then director-general of the Political Affairs Bureau, Koike Chōzō, was, along with Shidehara, one of the four individuals who had passed the fourth diplomatic service exam. Koike had remained in office from the time of the first Yamamoto Gonbè cabinet, where he was appointed under Foreign Minister Makino Nobuaki (1861-1949). The directorgeneral of the International Trade Bureau was Sakata Jūtarō (1868-1919). Sakata also had other important responsibilities that he had been carrying out for some time, since the period of the second Saionji cabinet and Foreign Minister Uchida Yasuya (1865-1936). Shidehara, meanwhile, had been director-general of the Investigation Bureau when Uchida was foreign minister. Given this similar background, we might wonder how Shidehara's own career trajectory compared. The vice-minister for foreign affairs who served under Foreign Minister Katō had been Matsui Keishirō. Matsui had been ahead of Shidehara at Osaka Middle School. Shidehara was four years younger than Matsui and was 43 years old when he took over as vice-minister for foreign affairs. 
When Shidehara returned to Japan in high spirits, something unexpected awaited him: thousands of Denison's books, delivered by the executor of Denison's estate. Shidehara had the executor show him Denison's handwritten will. As Shidehara recalls: '[I] read it thoroughly, multiple times, my heart filled with grief' ${ }^{83}$

Over the next four years, Shidehara carried out his duties as viceminister for foreign affairs, supporting five successive foreign ministers: Ishii Kikujirō, Terauchi Masatake, Motono Ichirō (1862-1918), Gotō Shinpei (1857-1929) and Uchida Yasuya. Excluding Uchida, who served as foreign minister for five years, including in the Hara cabinet, each of these foreign ministers served no longer than a year and a half (including Motono, who was the longest serving of these four). Shidehara plunged into his responsibilities as vice-minister, frequently working long into the night for days on end. According to Nagai Matsuzō (1877-1957), then director of the Telegraph Division, whenever Shidehara eventually returned home, the ministry would become much quieter. ${ }^{84}$

During Shidehara's term as vice-minister for foreign affairs, the administration changed from the second Ōkuma cabinet to the Terauchi cabinet and then to the Hara cabinet. There were many important issues that Shidehara would be involved with during this period. These can broadly be divided into the categories of Russo-Japanese relations, Sino-Japanese relations, American-Japanese relations and the Paris Peace Conference. Of these, it was Japan's relationship with Russia following the end of World War I that became more involved. In particular, the Fourth Russo-Japanese Agreement of July 1916 was close to a military alliance. At this time, Japan and Russia were sending members of their respective imperial families on state visits in order to publicly display their friendship. Naturally, Shidehara devoted great care to Japan's relationship with Russia at this time. ${ }^{85}$

Just after his appointment as vice-minister, Shidehara began exchanging information with resident Russian Ambassador Nikolai A. MalevskiiMalevich regarding Germany's intentions. For example, as rumours swirled of a German plan to sabotage the Chinese Eastern Railway, Shidehara shared information with the Russian ambassador about a German individual behaving suspiciously. The Chinese Eastern Railway was located in north-east China and was originally built by Russia. Cooperating with Russia in this manner was an approach that Shidehara carried over from his predecessor as vice-minister for foreign affairs, Matsui 
Keishirō. This approach was not unique to Shidehara. On the other hand, when Japan responded coldly to Yuan Shikai's imperial government plans, Malevich informed Shidehara that Russia would pursue the same policy. Incidentally, written communications between Russia and Japan were generally not in English but in French. ${ }^{86}$

What Russia dearly desired from the Japanese side was military supplies. However, the Ministry of War was not inclined to agree to the provisioning of Russia. Shidehara's solution was to work with the Ministry of War, the Ministry of Finance, and the Russian embassy to arrange for Russian treasury bonds to be paid in exchange for Japan's military supplies. Shidehara also worked to ensure that Japan's newspapers did not report sensitive news about Russia. ${ }^{87}$

On the economic front, fishing rights were regarded as particularly important. The Russo-Japanese Fishing Agreement, signed in July 1907, was for a period of 12 years. As early as 1916, however, the Fisheries Bureau of the Ministry of Agriculture and Commerce began surveying the Russian territorial coastline with an eye to the treaty's renewal three years later. Shidehara worked to accommodate these efforts by coordinating with Foreign Minister Ishii and the Russian embassy. ${ }^{88}$

\section{Sino-Japanese and American-Japanese Relations during World War I}

While Japan was strengthening its relationship with Russia, the situation in China was thrown into chaos as a result of the Chinese Revolution of 1911, which led to the overthrow of the Chinese Qing dynasty and the establishment of the Republic of China. In Manchuria and Inner Mongolia, there were even independence movements launched by parts of the Japanese army, and groups such as one led by Kawashima Naniwa (1865-1949), one of the so-called 'continental wanderers' who appeared in this period (independent Japanese who roamed continental Asia). Although the Ōkuma cabinet decided to attempt to remove Yuan Shikai in March 1916, his sudden death in June made it necessary to shift towards a policy of supporting President Li Yuanhong (1864-1928). This new policy meant ending earlier plans to assist independence movements in Manchuria and Inner Mongolia. Consequently, Shidehara supported the confiscation of weapons and ammunition in Changchun, working to obstruct the raising of independence armies. ${ }^{89}$ 
With respect to the new government in Beijing, there was the problem of China potentially participating in the conflict against Germany. While the UK, France and Russia had also asked the Chinese government to participate, Japan had opposed this move. Russian ambassador Vasilii N. Krupenskii pressed Shidehara as to why Japan opposed China's participation. Shidehara replied: 'It is hard to believe that China would be prepared to give up its neutral status to accept an offer from the Allies'. In other words, Shidehara responded that it was because China had not properly made up its mind about engaging in the war. In reality, however, Shidehara shared the same concern as Foreign Minister Ishii-that China might be able to improve its position by participating in the war. On the other hand, Shidehara was also anxious about China falling into a state of lawlessness and hoped that the forces in southern and northern China might reach 'a clear reconciliation'..$^{90}$

In October 1916, the Terauchi Masatake cabinet was formed. General Terauchi, who had for many years served as governor-general of Korea, temporarily served as foreign minister alongside his duties as prime minister. However, this ministerial post was soon taken over by Motono Ichirō. Motono had become Japan's minister to Russia in 1906. In May 1908, the legation was upgraded to an embassy, and Motono continued to serve as ambassador to Russia until 1916. Motono was deeply involved in each of the four Russo-Japanese agreements. Therefore, while Motono was very familiar with the general state of affairs in Europe, he was less knowledgeable about the Sino-Japanese relationship. Thus, Shidehara was able to enjoy an enhanced position within the ministry with respect to Chinese policy.

That said, Shidehara did not have complete control over how Japan responded to the situation in China. The leading individual in this area was the China expert Obata Yükichi (1873-1947). Obata had replaced Koike Chōzō as director-general of the Political Affairs Bureau. Having been critical of the Ōkuma cabinet's policy of intervention, Obata submitted a written opinion to Foreign Minister Motono that advocated the restoration of friendly relations with the other world powers. Shidehara assisted Obata in polishing the prose of this written opinion. Motono was able to receive private consent for this policy from figures such as Terauchi and Yamagata. The new policy direction, of establishing harmonious relationships with the world powers, was agreed upon in a meeting of the Terauchi cabinet on 9 January $1917 .{ }^{91}$ 
China's entry into World War I in August 1917 led to heightened tensions between Japan and the US. This was because the US had increased its involvement in China's internal affairs. US Minister Paul S. Reinsch took a leading role in pushing for this new approach. When the Wilson administration advised the Chinese government to put an end to that nation's internal conflicts, the Terauchi cabinet saw this as a form of interference. When Post Wheeler, the chargé d'affaires (the provisional ambassador) of the US embassy in Japan, visited the ministry to explain their position, Shidehara reminded him that the manner in which the Japanese were always particularly sensitive with regard to the problem of China was no different to Americans with respect to Mexico'. ${ }^{92}$

For this reason, Japan and the US needed to reach some form of consensus with respect to China policy. Japan's approach was to dispatch former foreign minister Ishii Kikujirō to the US. In November 1917, Ishii was able to conclude an exchange of notes with Secretary of State Robert Lansing (sometimes referred to as the Lansing-Ishii Agreement). In the agreement, the US recognised Japan's 'special interests' in China. Further, the accord stipulated that both nations would maintain equality of opportunity and open door policies as their ideals. It was a quintessentially ambiguous agreement. For the most part, however, its contents were regarded as satisfactory in Japan. After the accord was finalised, Ishii took over as ambassador to the US, and American-Japanese relations also improved regarding naval deployment in the Pacific. ${ }^{93}$

During this period Shidehara consulted with Foreign Minister Motono to help ensure that the negotiations between Ishii and Lansing proceeded as planned. Taking into consideration Shidehara's views, Motono had Satō, then ambassador to the US, deliver a memorandum to Lansing by hand. This memorandum cleverly included a passage stating that Japan had important political and economic interests in China. Shidehara took the additional step of showing this memorandum to Chargé d'Affaires Wheeler, indicating that Lansing 'expressed himself as quite in accord with the deep sense of the memorandum'. ${ }^{94}$ However, Lansing would later angrily refute this claim. Apparently, Shidehara's attempts here were actually counterproductive. Nevertheless, the conclusion of the agreement between Ishii and Lansing helped to ease tensions between the US and Japan. The diary of Undersecretary of State William Phillips is particularly illuminating on this matter. While Phillips was initially suspicious of 
Ishii, after some time they were able to speak candidly. Phillips wrote in his diary: 'The editorial comment this morning on the exchange of notes with Japan is very good, with the exception of the New York Times'. ${ }^{95}$

In the following year, 1918, a serious issue for Japanese diplomacy was the sending of troops to Russia in the wake of the Russian Revolution. The nations most enthusiastic about sending a coalition expeditionary force to quell the revolution were the UK and France. The Wilson administration in the US was more wary and hesitated to commit armed forces. In Japan, Foreign Minister Motono of the Terauchi cabinet strongly backed participating in the expedition. However, Shidehara's position was closer to the US's. He was cautious about the idea of sending troops. With Motono frequently ill at this time, Shidehara had the rare opportunity to freely present his own view to US Ambassador Morris, British Ambassador William Conyngham Greene, French Ambassador Eugène L. G. Regnault and Russian Ambassador Krupenskii. ${ }^{96}$

Nevertheless, the US gradually began to lean towards sending soldiers. Surprisingly, in July 1918 the Wilson administration proposed to Japan that they land a joint expeditionary force at Vladivostok. The pretext of this move would be to relieve the Czech army. In August, therefore, a Japanese-American joint military expedition was launched. However, Japan committed 73,000 soldiers, which the US saw as entirely too many. The Wilson administration and Undersecretary of State Phillips were also irritated at the actions of the Japanese army at that time. ${ }^{97}$

The end of September 1918 saw a change of government in Japan, with the formation of the Seiyūkai party's Hara Takashi cabinet. This was the first properly party-based cabinet. With the change in cabinet, Gotō Shinpei, who had served as the foreign minister for about five months towards the end of the Terauchi cabinet, was replaced by Uchida Yasuya. Uchida, who had once enjoyed the favour of Mutsu Munemitsu, had passed through the successive positions of director-general of the International Trade Bureau, director-general of the Political Affairs Bureau, minister to the Qing dynasty and ambassador to the US. In 1911, he became foreign minister in the second Saionji cabinet. He also served as the ambassador to Russia but had to return to Japan upon the outbreak of the Russian Revolution. 
The Hara cabinet set to work, seeking to reduce the size of the military force that had been sent to Siberia, as well as placing geographical limits on how far the army could move. It must be added that Shidehara's diplomatic activity after troops were deployed to Siberia was not simply targeted at fostering cooperation with the UK and the US. In his negotiations with these two nations, he frequently had to assert Japan's agreed-upon special interests in Manchuria. In particular, Shidehara disapproved of the proposal to internationalise the management of the Chinese Eastern Railway under the guidance of the US. He cited 'Japan's special status' in Manchuria. ${ }^{98}$

That said, Shidehara showed a different face domestically. On 26 October 1918, he attended a meeting with the army, alongside Political Affairs Bureau Director-General Obata. Together, they succeeded in winning over Major General Hoshino Shōzaburō, chief of the Third Bureau of the Office of Army General Staff. (The Office of Army General Staff was one of two agencies that managed the Imperial Japanese Army at that time.) Hoshino also opposed the US proposal to place the Chinese Eastern Railway under international management. Shidehara responded to his concerns by asserting that 'there is absolutely no fear of the US going back on its word, given its national character'. ${ }^{99}$

Shidehara was also critical of the inclusion of the Baikal Cossack chief (ataman) Grigorii Mikhailovich Semenov (1890-1946) in the Office of Army General Staff. Instead, Shidehara sought to strengthen Japan's relationship with Aleksandr Vasil'evich Kolchak (1874-1920), the navy admiral who had taken over governance of the city of Omsk, which the UK and France were supporting. Omsk was the centre of the anticommunist government in Siberia, supported by other leaders of the white movement. In practice, this meant that Japan helped supply Omsk with munitions, while also dispatching Katō Tsunetada (1859-1923) as temporary ambassador plenipotentiary. ${ }^{100}$ The government in Omsk was short-lived, however, collapsing in November 1919. Following the subsequent withdrawal of UK, French and US troops from Russia, the Japanese army became the last Allied forces in the former Russian Empire.

At this time another issue with the US began to emerge. The Wilson administration reached out to Japan, the UK and France about the possibility of the four nations jointly loaning money to the Chinese government. The syndicated loan that was established through this cooperation was known as the New Four-Power Consortium. Secretary of 
State Lansing first brought the proposal for this consortium to Ambassador Ishii in July 1918. However, Shidehara had some doubts. In a Tokyo meeting held in October with Ransford S. Millar, who would go on to become the chief of the Division of Far Eastern Affairs of the US State Department, Shidehara emphasised that this development could be 'the first step toward the abolition of [Japan's] sphere of influence', making its 'execution extremely problematic [for us]'. ${ }^{101}$ Behind the establishment of the New Four-Power Consortium was a plan by actors such as the Manchurian Railway Company to secretly expand the transcontinental railroad. Shidehara and Foreign Minister Uchida were well aware of this fact.

\section{The Paris Peace Conference}

January 1919 saw the commencement of the Paris Peace Conference, where the victorious powers set the terms for the conclusion of World War I. It was not until June that year that the Allied powers (including Japan) concluded a formal peace treaty with Germany: the Treaty of Versailles. At this conference, the Hara cabinet acted in concert with the UK while successfully negotiating Japan's inheritance of Germany's interests in the Shandong Peninsula. Japan was even able to establish the 'South Pacific Mandate', whereby Pacific islands north of the equator that had been part of the German Empire were placed under Japanese control. As viceminister for foreign affairs, Shidehara showed his discomfort with the diplomatic ideals of President Wilson. This was visible in his response to Wilson's Fourteen Points and to Wilson's call for the establishment of the League of Nations.

Wilson had given a speech to the US Congress in January 1918 in which he presented his vision for a liberal world order. The Fourteen Points that Wilson outlined in this speech included a call for the abolition of secret diplomacy and the establishment of a League of Nations. According to Mushanokōji Kintomo (1882-1962), who was director of the second division of the Foreign Ministry's Political Affairs Bureau, Shidehara's opinion on this plan for a League of Nations was that:

It is a great nuisance to have our fate decided at this kind of roundtable discussion, rather than through respective direct negotiations between countries that have an interest on a given matter. ${ }^{102}$ 
In fact, Shidehara opposed not only the League of Nations but also the later-established United Nations.

On the topic of the Paris Peace Conference, a fascinating anecdote about this period emerged after Shidehara became Japan's ambassador to the US. Secretary of State Lansing had criticised Japan in his memoirs for being so persistent in trying to secure interests in Shandong. ${ }^{103}$ Lansing's account appeared aimed at warding off critiques that he compromised with Japan too much with the Lansing-Ishii Agreement and during the Paris Peace Conference. Lansing was considerate enough to send a copy of these memoirs to Shidehara.

Shidehara's strong sense of pride shows through in the letter of thanks he wrote for this gift, which bristles with sarcasm. Shidehara wrote that Lansing's memoirs were highly 'instructive to me'. He continued:

It shows how little the actual situation and relevant history of the Far East are understood by even the foremost statesmen and scholars of this country, and how easily the best intentions and honest thinkings of one nation are liable to be misconstrued by another. I have, however, every confidence that Japan's position will someday be viewed in its truer and fairer perspective. ${ }^{104}$

Shidehara apparently encountered Lansing and his wife at a tea party shortly afterwards, leading to no small amount of awkwardness. Shidehara sent a copy of this letter of thanks addressed to Lansing to Makino Nobuaki, minister of the imperial household, via Vice-Minister for Foreign Affairs Hanihara Masanao (1876-1934). Substantially, Makino had been Japan's chief plenipotentiary at the Paris Peace Conference.

\section{A Time of Trials for the Foreign Ministry-Katō Takaaki and Hara Takashi}

So far, I have traced Shidehara's participation in events pertaining to RussoJapanese, Sino-Japanese and American-Japanese relations, as well as with respect to the Paris Peace Conference. The reader may therefore have been left with the impression that Shidehara was practically the architect of Japan's diplomacy during World War I. However, this was not the case. It was not until the Washington Naval Conference that Shidehara would come to lead Japan's diplomatic efforts and make a name for himself. In fact, more generally, World War I was a time of trials for the Ministry of Foreign Affairs, which saw its status within the government deteriorate. There were five reasons for this state of affairs. 
First was the intervention in foreign affairs by Japan's elder statesmen, the genrō. For example, the Fourth Russo-Japanese Agreement, concluded in July 1916, was advocated by two genrō: Yamagata Aritomo and Inoue Kaoru.

Second, the Extraordinary Foreign Diplomacy Investigation Committee was established in June 1917 by the Terauchi cabinet. Alongside figures such as Privy Councillor Itō Miyoji (1857-1934) and Makino Nobuaki, members of this committee also included presidents of two political parties: Seiyūkai President Hara Takashi and Kokumintō President Inukai Tsuyoshi (1855-1932). Together they would convene and deliberate upon Japan's diplomatic problems. We may regard this as the beginning of the direct involvement of political parties in Japanese diplomacy. ${ }^{105}$

A third reason was the existence of the army. Leading the army during its Siberian Intervention were individuals such as Vice Chief of Army General Staff Tanaka Giichi. After troops were dispatched to the continent, the Office of Army General Staff worked independently in assisting pro-Japanese factions.

Fourth, private citizens such as Nishihara Kamezō (1873-1954) were involved behind the scenes in Japan's China policy, promoting the lending of money to the Chinese government. The 'Nishihara Loans' were further supported by Finance Minister Shōda Kazue (1869-1948).

Finally, there was the problem of government organisation in Manchuria. The Resident Generals Office of Kwantung was abolished in 1919, with the Kwantung Territory Government established in its place. The Kwantung Territory Government had jurisdiction over a leased territory known as Guandong (usually known as Kwantung, in Japanese, Kantō), located on the south-western tip of the Liaodong Peninsula. It also functioned as the office for policing the Manchurian Railway. The head of the Kwantung Territory Government was the chief of the Kwantung Territory Government. The chief of the Kwantung Territory Government was a civil service employee who, according to regulations, was under the supervision of the foreign minister when it came to negotiations. At the same time, the military division that belonged to the former Resident Generals Office of Kwantung was turned into the independent Kwantung Army, headquartered in the city of Lushun. 
What this meant was that, alongside the various consulates general and the South Manchuria Railway Company, there was now the Kwantung Territory Government and the Kwantung Army, turning Japanese governance in Manchuria into a four-pronged political structure. Long gone were the days when Japanese diplomacy in the region was based only on the Ministry of Foreign Affairs.

In such a situation, it was inevitable that Shidehara would want the Ministry of Foreign Affairs to enjoy greater power. Yet Shidehara rarely expressed these views in public directly. Shidehara's measured stance became all the more conspicuous when contrasted with that of Katō Takaaki, who, although occupying a different position within the government, frequently argued for the centralisation of diplomacy.

Previously, Katō had taken up his first cabinet posting as foreign minister in the fourth Itō cabinet, in which he argued forcefully for a hard line against Russia. Later, in the first Saionji cabinet, Katō would clash with the military over policy in Manchuria and quit his post as foreign minister. When he again became foreign minister in the third Katsura cabinet, he made centralisation of diplomatic power his condition for accepting the post. Further, as foreign minister in the second Ōkuma cabinet, Katō antagonised the genrō by blocking their access to confidential documents. Katō also refused to participate in the Extraordinary Foreign Diplomacy Investigation Committee, on the grounds that it went against his principle of diplomatic centralisation. Katō also worked vigorously towards the realisation of one more dream: the establishment of a two-party system. ${ }^{106}$

Before long, Shidehara and Katōss respective directions would overlap. The occasion was Katō's establishment, in 1924, of the three-party coalition cabinet of constitutional protection (Goken Sanpa), which he led as prime minister. Shidehara would become foreign minister in Katō's cabinet, although Shidehara had never sought to use Katō for his own gain. However, while Katō did attempt to promote the centralisation of diplomatic power within the government, his record as foreign minister was poor. Indeed, it was stained by the debacle of the Twenty-One Demands of 1915. For that reason alone, Katō would leave diplomatic matters to Shidehara once he assumed the position of prime minister. Assuming this new position, Shidehara would surely have been conscious of the difficult experiences his brother-in-law had undergone before him. 
Compared to Katō, Shidehara's record as foreign minister was faultless. He was able to assist not only Ishii Kikujirō, Terauchi Masatake, Gotō Shinpei and Hara Takashi but also the group of individual personalities that was the genro. Conversely, it is hard to avoid the conclusion that his time in office was somewhat unremarkable. Yet there was a reason for this. Simply put, the times were changing. With the gradual establishment of various diplomatic organisations and systems, alongside the emergence of truly party-led cabinets, what the Ministry of Foreign Affairs most needed was skilled officials. It was no longer the age of heroic diplomatic figures, as in the days of Mutsu Munemitsu or Komura Jutarō.

That said, skilled officials can still be particular when it comes to their acquaintances. Shidehara was fortunate to have his connection with Hara Takashi. When the Hara cabinet sought to scale back the excessive aid that had thus far been given to the Chinese warlord Duan Qirui (1865-1936), Shidehara lent his support. At the beginning, Hara and Shidehara's relationship was not exactly amicable. When Shidehara initially assumed the position of vice-minister for foreign affairs, Hara and Yamagata suspected him of being aligned with their rival, Katō Takaaki. Yet Hara found himself gradually trusting Shidehara more over time. Shidehara's selection as ambassador to the US reflected the seriousness with which Hara viewed Japan's relationship with that nation. ${ }^{107}$

\section{The Washington Naval Conference}

\section{Japan's Embassy in the US}

In modern terms, the elite diplomats of Japan's Ministry of Foreign Affairs can hope for no higher career achievement than to be assigned ambassador to the US, following a stint as vice-minister. In other words, the situation has hardly changed since the prewar era. Of course, in Shidehara's day, it was also possible for a government official to advance one step further and take on the position of foreign minister. At that point there were only six Japanese embassies around the world-in the UK, France, Russia, Italy, the US and Germany. The diplomatic establishments in places such as Belgium, the Netherlands and China were only legations. 
Of the overseas diplomatic establishments of the earlier Meiji era, the most important would surely have been the British legation. Famous ministers to the UK included figures such as Katō Takaaki and Hayashi Tadasu. However, past ministers to the US were by no means inferior. Beginning with Mori Arinori (1847-1889), these distinguished individuals include Yoshida Kiyonari (1845-1891), Terashima Munenori (1832-1893), Mutsu Munemitsu, Hoshi Tōru (1850-1901), Komura Jutarō and Takahira Kogorō (1854-1926). At the end of the Meiji era, the legation was upgraded to an embassy, with Aoki Shūzō (1844-1914), Uchida Yasuya, Chinda Sutemi, Satō Aimaro (1857-1934) and Ishii Kikujirō successively serving as ambassador to the US. After Ishii left the post, embassy counsellor Debuchi Katsuji served as chargé d'affaires starting June 1919. In November of the same year, Shidehara would arrive in the US to fill the position. He was then 47 years old.

Just after Shidehara became ambassador, the US Congress made an unexpected decision. The Senate rejected the Treaty of Versailles. There was already a degree of conflict between Japan and the US surrounding the issue of Yap Island, which the League of Nations had decreed was now Japan's mandated territory, and it was feared that further fallout might result from the rejection of the treaty. ${ }^{108}$ Yap Island is one of the western Caroline Islands, an island group located in the Western Pacific Ocean. It is also close to Guam, which was already US territory at that time. Previously, Yap Island was under the control of Germany, but Japan had occupied it by force in 1914, during World War I.

From the time when Debuchi transferred to the position of counsellor at the embassy in Germany, until the arrival of Furuya Shigetsuna in April 1920, the embassy in the US had no counsellor. Assisting Shidehara was First Secretary Saburi Sadao and Hirota Kōki. During this period Shidehara had to place his complete trust in Saburi. However, Saburi was still a young diplomat, and his reputation was poor. Though he possessed a keen intellect, Saburi was known to be so faithful to his duties that he came across as somewhat aloof. It would take time before Shidehara was able to speak with him frankly. By contrast, Hirota was a popular figure among other young diplomats, such as Third Secretary Ishii Itarō. Although Hirota was Saburi's junior by a year, there was something philosophical about his thinking, and he seemed to hold great promise. ${ }^{109}$ 
Other staff at the embassy included Third Secretary Shiratori Toshio (1887-1949) and probationary diplomats Ōhashi Chūichi and Morishima Morito. Ōhashi and Morishima disapproved of Shidehara, finding his instructions to his subordinates insufficient. However, Shidehara paid this no notice. To him, such complaints were only a reflection of overreliance upon others due to a lack of independence. What Shidehara wanted was talented subordinates such as Saburi who would faithfully carry out his commands. The military attaché to the embassy was Major General Inoue Kazutsugu. The naval attaché was Lieutenant Colonel Ueda Yoshitake, who was later succeeded by Colonel Nagano Osami (1880-1947). Lieutenant Commander Yamamoto Isoroku (1884-1943) was also in the US at that time, and Shidehara had already formed the opinion that he was an able individual. ${ }^{110}$

\section{The Siberian Intervention Force and the Yap Island Problem}

Many of the diplomatic problems facing Shidehara were inherited as part of the legacy of World War I. The most troublesome of these was the Siberian Intervention force. Although the Hara cabinet expressed a sincere intention to reduce the number of Japanese troops in Siberia, the Wilson administration remained suspicious of Japan.

In early January 1920, Japan was suddenly informed that American troops would be removed. Although the deployment of troops to Siberia was a joint US-Japan undertaking in name only, for Shidehara this sudden withdrawal amounted to a humiliation. First, the US announcement was made without prior consultation with Japan. Second, the announcement was directly relayed from the expeditionary force commander, William S. Graves, to the Japanese commander of the Vladivostok expeditionary force, General Ōi Shigemoto, bypassing Shidehara altogether.

The astonished Shidehara expressed his outrage at Lansing, writing:

On what possible basis can the U.S. government decide upon the withdrawal of military forces and railway engineers and simply report this decision without any prior negotiation with the Japanese government? ${ }^{\text {111 }}$

However, the withdrawal was a fait accompli. For the rest of his life, Shidehara was unable to set aside the memories of this humiliating event. It constituted the largest blemish upon his record as ambassador to the US. 
It must be added that the Wilson administration was not united on the decision to withdraw from Siberia. Numerous officials supported a continuation of the expeditionary force. The central figure in this camp was the chief of the State Department's Division of Russian Affairs, Clinton Poole. Secretary of State Lansing was also of a similar mind. It should also be noted that Poole had a good relationship with the chief of the Division of Far Eastern Affairs, John MacMurray. However, as Poole himself explained, he did not call for the continuation of the expeditionary force in order to foster a harmonious relationship with Japan. Rather, Poole had previous experience in Russia and, as an anti-Bolshevik, he was concerned about the devastation taking place in the country. There is no evidence that Shidehara had properly understood this tendency among the Americans and used it to build a cooperative relationship. ${ }^{12}$

The legacy of World War I with respect to relations between Japan and the US extended beyond the issue of the Siberian Intervention force. When Japan entered World War I, it captured the German stronghold in Qingdao, effectively taking over Germany's interests on the Shandong Peninsula. Moreover, the territory occupied by Japan during the war was not limited to the Shandong Peninsula. Japan also took control of the South Sea Islands, a region of far more importance in relations with the US. ${ }^{113}$ During the war, the Japanese navy occupied the Mariana Islands, the Caroline Islands, and the Marshall Islands (previously German territory), placing them under military administration. These South Sea Islands were turned into a mandated territory under Japanese control as a result of the Paris Peace Conference.

There were a number of mandated territories following World War I. This term referred to those former German and Ottoman territories that were governed by other nations under the mandate of the League of Nations. The form of governance to be deployed in these territories was categorised into Class A, Class B and Class C according to factors such as geographical location, economic status and living standards. Former Ottoman territories in the Middle East were categorised as Class A. Former German territories in East Africa and Central Africa were categorised as Class B. Former German territories in South-West Africa and the Pacific were categorised as Class C. Class A governance meant that the mandatory power had only limited authority. Class C, however, was more like outright annexation. 
Of the Class $\mathrm{C}$ territories, the formerly German-controlled South Sea Islands that were north of the equator were entrusted to Japan, which had already placed them under military administration. There was one more Class C territory on the western edge of the Caroline Islands (located in the Western Pacific): the small island of Yap. The US was not pleased with Japan becoming the mandatory power for Yap Island. This is because it was in a critical area for the laying of submarine cables. ${ }^{114}$

Just before Shidehara left Japan for the US, he asked that the Japanese navy undertake a survey of the prescribed rights of foreigners in the South Sea Island, former German territories. After Shidehara left for his new posting as ambassador, the Special Micronesia Defense Corps completed the survey of the South Sea Islands. ${ }^{115}$ Meanwhile, the US maintained that the Yap Island submarine cables should be placed under international administration. Shidehara would engage Undersecretary of State Norman Davis in a heated debate on this topic on 8 October 1920. There was also a Preliminary International Conference on Electrical Communications held in Washington, with Davis appointed as chairman. Shidehara was in attendance, along with Saburi. There the US attempted to have Yap Island removed from Japan's mandated territories. In February 1921, Secretary of State Bainbridge Colby (1869-1950) submitted a letter of protest to the Council of the League of Nations. ${ }^{116}$

In March 1921, Warren G. Harding was inaugurated as president of the US. His was the first Republican administration in eight years. The secretary of state was Charles Evans Hughes (1862-1948). The Harding administration was also reluctant to acknowledge Japan's mandate over Yap Island. Some form of resolution was necessary. It is here that Shidehara suggested a course of action to Foreign Minister Uchida. Shidehara's idea was for Japan to offer a proposal to the US; if it acquiesced to Japan's mandate over Yap Island, then Japan would open up submarine cable unloading and management to the other world powers. Upon hearing of this offer, Secretary of State Hughes, who had until then strongly opposed Japan's rights over the island, began to search for points of compromise. ${ }^{117}$ After further negotiation, Shidehara and Hughes were finally able to conclude an agreement that included Japan's Yap Island mandate. The agreement was signed on 11 February 1922. In exchange for recognising Japan's mandate, the US received permission from Japan to unload and operate the submarine cable connecting Yap and Guam, as well as any future cables that would connect to Yap. ${ }^{118}$ 
During this period, Shidehara was visiting the State Department practically every day, which eventually took a toll on his health. He was initially diagnosed with kidney inflammation, but it turned out to be a kidney stone. When the Washington Naval Conference began in November 1921, Shidehara was largely confined to bed. The following year, when he became acting prime minister for a period during the Hamaguchi cabinet, he was still suffering badly from the condition. In any case, Japan abolished military administration on the South Sea Islands and, in April 1922, established the Government Office of the South Sea Islands (Nanyōcho), located on Koro Island, part of the Palau Island group, located on the western edge of the Caroline Islands. Branch offices were set up in six locations, including Yap and Saipan. ${ }^{119}$ The South Sea Islands remained under Japanese administration until the end of the Pacific War, after which they became entrusted to the United Nations, which in turn delegated their administration to the US.

\section{The Anti-Japanese Immigration Issue}

Along with the Siberian Intervention force and the mandate of Yap Island, there was also the serious issue of the movement in the US to block Japanese immigration. Shidehara had to grapple with this problem once he became ambassador to the US during the Wilson administration. Shidehara was well versed in the immigration issue due to his past experience as embassy counsellor, where he lent support to the talks held in 1913 between Chinda Sutemi and William Jennings Bryan. First, Shidehara informed the US that Japan was voluntarily prohibiting its women from immigrating to the US to be brides in prearranged 'picture marriages' - a practice that inflamed anti-immigration sentiment among Americans. Then, in February 1920, Japanese labourers held a largescale strike at a sugar cane farm in Hawaii. Here, too, Shidehara took the conciliatory move of informing Undersecretary of State Frank Lyon Polk that he had instructed the consul general to 'do all he could to restore order'. ${ }^{120}$

Despite Shidehara's best efforts, the state of California was moving towards the enactment of a Second Alien Land Law that would prohibit people of Japanese ethnicity from leasing land. Further, there was little hope that US Secretary of State Bainbridge Colby would offer any measures to counter this development. This was because Colby had only just taken over from Lansing in March 1920. It was at this time that Roland S. 
Morris returned from his term as ambassador to Japan and was able to assist in resolving the issue. With the commencement of negotiations surrounding the immigration issue, which were suggested by the US, talks between Shidehara and Morris began to reveal a potential way forward. ${ }^{121}$

Shidehara and Morris began their series of talks in September 1920. By January 1921 they had met 23 times. Shidehara's position was that there should be a reform of the gentlemen's agreement between Japan and the US, so that anti-Japanese movements in the US could be mitigated. Because the talks with Morris were unofficial, Shidehara's role was all the larger. A difficult event that occurred in the middle of their discussions was the passing of the Second Alien Land Law in California. Despite this discouraging development, Shidehara persisted, continuing the negotiations with Morris until a new treaty draft was prepared. Yet progress on this front was foiled by a transition in the US government to the Harding administration, which was not willing to move forward with the treaty draft. ${ }^{122}$

Following his return to the US, Morris became the first honorary president of the America-Japan Society, which had been founded during World War I. Shidehara's name was also formally recorded as one of the people who initially proposed this society. Morris would later invite Shidehara to attend some of the lectures that he gave in the US. With Shidehara in the audience, Morris stated: 'There are no questions between Japan and the United States which, if approached in a generous spirit of confidence and candor, are not susceptible to a just and honorable solution'. ${ }^{123}$

\section{Concerns Surrounding the Crown Prince's Visit to the US}

During Shidehara's repeated talks with Morris, Prime Minister Hara Takashi was holding his own discussions in Tokyo with Yamagata Aritomo, the genrō. Their topic was the possibility that Crown Prince Hirohito Shinno might travel abroad. Hara and Foreign Minister Uchida supported the idea of the crown prince visiting not only Europe but also the US. ${ }^{124}$

Shidehara, however, was extremely apprehensive about this idea. Shidehara remembered what happened to Edward, the Prince of Wales (later King Edward VIII). When Edward had visited the US two years earlier, the trip had exhausted him, in part because of the 'bad manners' of the Americans. Given this concern, Shidehara wrote to Uchida: 
Even if His Highness, our crown prince, were to come to the U.S., because the state of our nations is so different, the crown prince would be placed in a position of having no option but to endure not only physical discomfort but also the rudeness of the ordinary people. For example, even if people of no standing approach His Highness and address him in a familiar manner, then His Highness is placed in a position in which he must nevertheless give an appropriate response, without which he may unavoidably give the impression of being rude. ${ }^{125}$

In other words, Shidehara felt that the national conditions of the US were simply too different, given that the country had nothing comparable to Japan's imperial household. Amplifying this sense of unease was the press reporting. Previously, Shidehara had personally witnessed a reporter disrespectfully asking Prince Edward directly for a copy of his prepared speech. At this already delicate time in US-Japan relations, it was not impossible for things to develop in unforeseen ways as a result of Japan's press reporting. Shidehara's warnings were heeded, and the crown prince's overseas trip was confined to Europe. While the Hara cabinet refused the invitation from the US president, they were able to settle the matter by having the Taishō emperor send a personal telegram.

\section{The Washington Naval Conference}

From November 1921 to February 1922, the Harding administration sponsored an international naval conference in Washington. Representatives from nine nations attended, including the UK, France, Italy, Japan, China and the US itself. The main topics of the Washington Naval Conference were naval restrictions and the situation in the Far East and the Pacific. Discussion of these issues led to the forming of three major treaties: Five-Power Treaty, Nine-Power Treaty and Four-Power Treaty.

Japan's chief delegate for the naval restrictions negotiations was Navy Minister Katō Tomosaburō (1861-1923). At the beginning of the conference, Secretary of State Hughes made the bold proposal that naval construction be prohibited for a 10-year period, with capital ship inventory between the US, the UK and Japan maintained at a ratio of 5:5:3. The originality of Hughes's proposal meant that it was received as a 'bombshell'. Some in the Japanese navy staunchly opposed it, such as Vice Admiral Katō Hiroharu (1870-1939), who sought a 70 per cent 
ratio vis-à-vis the US. However, Katō Tomosaburō accepted a 60 per cent ratio, taking into consideration the burden of naval expenditures as well as the fostering of a cooperative relationship with the US.

In February 1922, Japan, the US, the UK, France and Italy signed the Five-Power Treaty, which restricted navy armaments. In exchange, Katō Tomosaburō, as noted in Article 19 of the Five-Power Treaty, had the US admit that it would not construct any fortresses or naval bases on Pacific islands. However, as there were no armament restrictions on auxiliary vessels, it was not long before the world powers once more entered a warship-building race with respect to these smaller ships.

Shidehara's involvement in the Washington Naval Conference was primarily focused on discussions surrounding the 'Far East problem' and the 'Pacific problem'. Here, the 'Far East problem' referred to issues of international order relating to China and the interests in Shandong. The 'Pacific problem', meanwhile, concerned the continuation or termination of the Anglo-Japanese Alliance. To help deal with the related negotiations, Vice-Minister Hanihara Masanao and American and European Bureau Director-General Matsudaira Tsuneo were sent to Washington from the Ministry of Foreign Affairs in Tokyo. Hanihara, in particular, was invested with plenipotentiary and would in fact later become Shidehara's successor as ambassador to the US. Hiroshi Saitō (who Shidehara had referred to as a 'master of English') and Shiratori Toshio also attended. ${ }^{126}$

The Japanese government's underlying position was that they did not wish to have a debate on the Pacific or Far East problems. Shidehara's advice, however, was the opposite. According to Shidehara, because Secretary of State Hughes was not knowledgeable about the Pacific or Fast East problems, it would be advantageous for 'Japan, which has interests of vital importance at stake, to make the first move in setting the agenda for discussion'. ${ }^{127}$ This difference in enthusiasm between Shidehara and Tokyo would be most visible with respect to discussions surrounding the termination of the Anglo-Japanese Alliance.

With respect to the Far East problem, in February 1922, the Nine-Power Treaty concerning China was signed at the Washington Naval Conference. It was criticised at the time for lacking any provisions for punishment in the event of non-compliance. However, what is probably even more important was the manner in which the open door policy clause was interpreted. The term 'open door' is quite ambiguous. In the open door 
policy notes issued by Secretary of State John Hay, there are two main types of open door policy. In the first open door policy note, dating to September 1899, Hay sought equality of opportunity in the sphere of commerce. On the other hand, in the second open door policy note of July 1900, Hay stipulated the territorial and governmental integrity of China. ${ }^{128}$ Secretary of State Hughes also emphasised the importance of the open door policy as a basic principle. ${ }^{129}$

So, what did an open door policy mean for Shidehara? As his writing indicates, here too Shidehara was influenced by Denison. In the past, when Denison was drafting the First Anglo-Japanese Alliance at the instructions of Foreign Minister Komura, he 'avoided the ambiguous terminology of having an "open door"'. Instead, the preamble included the words: 'in securing equal opportunities in those countries for the commerce and industry of all nations'. This was the first time that the term 'equal opportunities' was used in a convention. Later, in the preamble to the Second Anglo-Japanese Alliance, Denison referred to 'the principle of equal opportunities for the commerce and industry of all nations in China'. The same term also made an appearance in the preamble of the Third Anglo-Japanese Alliance, as well as in Article 3 of the Treaty of Portsmouth. Shidehara also understood the 'principle of equal treatment' that appears in the Franco-Japanese Treaty of 1907 as being the same concept. ${ }^{130}$

Based on the above, we can assume that Shidehara understood the concept of an 'open door' policy as meaning the embracing of equality of opportunity-in other words, the sense shown in the first policy note issued by Hay. Further, given that the open door principle was also included in the terms of the Anglo-Japanese Alliance and the FrancoJapanese Treaty, it could hardly be regarded as an ideal that was unique to US diplomacy.

In the case of the Nine-Power Treaty, however, the first item utilises the term 'open door' in a sense that is closer to the second policy note issued by Hay: '[Signatories agree to] respect the sovereignty, the independence, and the territorial and administrative integrity of China'. Meanwhile, the third article of the same treaty uses this term in a sense closer to Hay's first policy note: 'With a view to applying more effectually the principles of the Open Door or equality of opportunity in China for the trade and industry of all nations'. Of these two sections of the treaty, it was the third article that Shidehara regarded as important. As he understood it, equality 
of opportunity was needed with respect to 'economic development' on the Chinese continent. ${ }^{131}$ To put it another way, Shidehara was not inclined to interpret the open door clause in the sense of the second note, which would mean respecting China's territorial and governmental integrity.

Of course, this did not necessarily mean that he rejected the principle of China's territorial and governmental integrity. It was rather that, for Shidehara, the reality of the situation on the continent meant that this was not a useful guiding principle for diplomatic activity. One example of how Shidehara perceived this diplomatic reality was the discussion during the Washington Naval Conference of the international administration of the Chinese Eastern Railway, which was located in Manchuria. From the time of the Siberian Intervention, the Chinese Eastern Railway had been managed by the combined international efforts of nations including Japan, the US, the UK and France. At the Washington Naval Conference, the US wished to reinforce this state of affairs. Although Shidehara was initially inclined to agree to the international administration of the Chinese Eastern Railway, led by the US, he was later swayed by Foreign Minister Uchida's more cautious thinking and eventually rejected the proposal.

Even when Hughes attempted to establish an international investigative body that would look into open door principles, Shidehara ensured that it would be toothless. Shidehara was particularly opposed to any US political involvement in Manchuria. This attitude is also visible in the way in which, as foreign minister, he responded to the Sino-Soviet conflict in 1929. It appears that, in reality, Shidehara interpreted 'open door policy' in a narrow sense. ${ }^{132}$

\section{Resolving the Shandong Issue - the US State Department's View of Japan}

Of the various diplomatic issues regarding the Far East at that time, the most serious for Japan was the inheritance of the interests in Shandong Peninsula. During World War I, Japan seized Germany's interests on Shandong. Later, at the Paris Peace Conference, it succeeded in having its control of these interests recognised by other foreign powers. However, the Chinese representatives refused to sign the Treaty of Versailles, meaning that the issue of the interests in Shandong lingered and was later brought up at the Washington Naval Conference. 
Shidehara was able to resolve the Shandong problem at the Washington Naval Conference, in part because he had worked to gain the support of figures such as John MacMurray, chief of the State Department's Division of Far Eastern Affairs. In a February 1922 treaty between Japan and China that concerned issues relating to Shandong, Japan redeemed the value of the railway assets through 15 -year-term treasury bonds from China. The treaty also stipulated that during the redemption period for those bonds, the posts for chief of transportation and chief of accounting would both be filled by Japanese. Meanwhile, the local mines would be placed under joint Sino-Japanese management. Japan was largely satisfied with this compromise, in which, although it would eventually lose the Shandong railway to China, it would receive suitable repayment and, for the time being, the right to make appointments to the top management positions. In his memoirs, Shidehara wrote that 'China intended to make the [negotiations surrounding the] Shandong issue collapse'. However, he added that, with the intervention of the US and the UK, China 'saw that the situation was not developing in their favour, and hence completely changed their attitude'. ${ }^{133}$

Under Division of Far Eastern Affairs Chief MacMurray were two individuals responsible for China and Japan, respectively: Nelson Trusler Johnson and Edwin L. Neville. Johnson, who was highly knowledgeable about China, died suddenly in 1954 . However, just before he died, he agreed to a lengthy interview about his experiences. In this interview, Johnson stated that, during the Washington Naval Conference, he felt that Japan, as well as the Anglo-Japanese Alliance, constituted a threat to US interests in the Far East. ${ }^{134}$ Sympathy towards China was quite deeply rooted in the US State Department.

In that sense, Edward Thomas Williams (who would have been Johnson's senior if he were still at the State Department) was no exception. Following a long period of initially working in China, Williams went on to enter the Division of Far Eastern Affairs in 1913, where he remained for five years. In 1918, he became a professor at the University of California, Berkeley, and went on to write numerous books on China's foreign relations. During the Paris Peace Conference, Williams attended as an adviser on Far East issues and was also a State Department adviser at the Washington Naval Conference. For this reason, he was in a position to offer counsel to Secretary of State Hughes during the naval conference on matters such 
as Shandong. Williams was even capable of offering detailed opinions to MacMurray, the Division of Far Eastern Affairs chief, on topics such as the provision on Chinese tariff treaties. ${ }^{135}$

Though he now lived in Washington, Williams, who was fluent in Chinese, had near-daily conversations with Shi Zhaoji (Alfred Sao-ke Sze) (1877-1958), China's ambassador to the US. Shi would also confide in Williams and, on occasion, would privately show him telegrams sent to him from the government in Beijing. The two even went for drives together. Williams also tried to get MacMurray to inform him about Shidehara's diplomatic movements. Meanwhile, Williams was very suspicious of Saburi, who was effectively Shidehara's right-hand man. By this point, Saburi had already risen up the ranks to become embassy counsellor. Regarding the matter of Shandong, Williams also consulted thoroughly with Stanley K. Hornbeck, an old acquaintance and a member of the State Department's Division of Far Eastern Affairs.

Reflecting on his experiences with the Paris Peace Conference, Shidehara came to distrust Williams even more. He wrote:

While occupying the post of advisor to the U.S. committee during the Paris Peace Conference, Williams would continually offer advice to the Chinese committee. Even worse, he would take actions in direct opposition to Japan. It is an undeniable fact that the extreme complications that emerged regarding negotiations involving China stemmed from the actions of Williams and his sympathizers. ${ }^{136}$

Meanwhile, from Williams's perspective, MacMurray's proposed solution for Shandong was too conciliatory. The thought of Japan being left with a foothold on the Shandong Peninsula kept Williams up at night. Instead of sleeping, he would type letters to MacMurray and Hughes, calling for a different course of action. Further, when topics came up on the agenda such as how to deal with the foreign troops stationed in China, or whether foreign post offices in China would continue to be permitted, here too Williams would show concern over Japan's movements. ${ }^{137}$

Finally, at the fifth general meeting on 1 February 1922, it was decided that foreign troops not stationed as part of a treaty needed to be withdrawn, and that foreign post offices had to be abolished. The Nine-Power Treaty was signed five days later. With respect to important matters such as Japan's interests in Shandong, there is little evidence that Williams's suggestions 
were adopted. ${ }^{138}$ However, Williams's sympathy towards China was passed on to Johnson and Hornbeck. Given that both individuals would go on to become chief of the Division of Far Eastern Affairs, it can be said that pro-Chinese officials in the State Department held more sway than proJapanese ones. From the perspective of the pro-Chinese faction, it could hardly be said that a Japanese-American cooperative framework had been established at the Washington Naval Conference.

\section{The Four-Power Treaty and the Termination of the Anglo-Japanese Alliance}

At around this time, in December 1921, the Four-Power Treaty was concluded at the Washington Naval Conference. The signatories of the Four-Power Treaty promised to maintain the status quo in the Pacific, and its ratification simultaneously led to the termination of the Anglo-Japanese Alliance. Shidehara also played a decisive role in this development. The Third Anglo-Japanese Alliance, signed in 1911, was valid for 10 years. Opinion had been divided within the British Empire as to whether the alliance ought to be renewed. While Australia and New Zealand hoped to defend against any possible future invasion by keeping Japan within the alliance, nations such as Canada and South Africa saw the alliance as a hindrance to cooperative relations between the UK and the US. In the end, the Anglo-Japanese Alliance was ended as a result of the conclusion of the Four-Power Treaty at the Washington Naval Conference. The formation of the Four-Power Treaty and the formal termination of the alliance took place in three stages, outlined below.

The first stage was the drafting of a proposal by the UK's chief delegate, Arthur James Balfour. Balfour, who was prime minister at the time of the signing of the Second Anglo-Japanese Alliance, had also served as navy minister and foreign secretary. His proposal was the formation of a triple entente that would include the US as a third nation. With the Balfour proposal, care was taken to gain the approval of the US, while at the same time preserving the freedom for Japan and the UK to restore a military alliance in the future. In effect, therefore, the proposal amounted to an attempt to maintain the Anglo-Japanese Alliance. Balfour went on to present this proposal to Katō and Hanihara.

The next stage was a counterproposal by Shidehara. Referring to Balfour's proposal, he made significant revisions in order to make it more palatable to the US. A distinguishing feature of Shidehara's proposal was that 
it specified that the triple entente would take the place of the AngloJapanese Alliance altogether. In other words, it watered down the effective continuation of the alliance that was contained in Balfour's proposal. Shidehara also took the step of presenting this proposal to Balfour without first receiving instructions from Tokyo. Once Balfour had made his own adjustments, Shidehara personally delivered the revised proposal to Hughes.

The third stage was Hughes's own proposal. Having received the revised proposal from Shidehara, he proposed the inclusion of France. With China excluded, this meant a treaty that would be adopted between four powers. ${ }^{139}$ The resulting Four-Power Treaty was signed on 13 December 1921. Article 4 of the treaty explicitly abolished the Anglo-Japanese Alliance.

Shidehara's solution with respect to this treaty has received occasional criticism. Some have argued that Shidehara made a mistake in judgement and that it should have been possible to avoid abolishing the AngloJapanese Alliance. ${ }^{140}$ Certainly, if we look back over Japanese government policy at that period, we can see that it merely accepted the termination of the alliance only when the UK were to advance such a proposal. However, the Japanese government's preference was to maintain the alliance if possible. In contrast to the detailed instructions that were issued with respect to the Far East problem, Tokyo's policy on the continuation or termination of the Anglo-Japanese Alliance was fluid. ${ }^{141}$

For this reason, Shidehara had more room than usual to exercise discretion. But, in that case, was there a chance that the Anglo-Japanese Alliance could have been saved? If there was such a possibility, it would have been through Balfour's proposed triple entente between Japan, the UK and the US. Shidehara himself has emphasised that there were problems with communication concerning Balfour's proposal. That is to say, when Balfour suggested to Hughes that the three nations form an entente, Shidehara said, 'I was indisposed due to illness and was completely unaware that this had happened'. ${ }^{142}$ It was actually Saburi who received word of the proposal from the US State Department.

When Shidehara then dispatched Saburi to speak with Balfour, it emerged that Balfour had already sounded out Plenipotentiary Tokugawa Iesato (1863-1940) with respect to the proposal. Yet, given that issues concerning the Pacific and the Far East-including the Anglo-Japanese Alliance- 
were being managed by Shidehara, Tokugawa felt that Balfour needed to negotiate directly with Shidehara. The situation was complicated by the fact that the UK's secretary-general, Maurice Hankey, actually forgot to hand over the full text of the triple entente. ${ }^{143}$

However, while this is how Shidehara recollected the events of this period, the fact is that, as noted above, Balfour did directly submit his proposal to Katō and Hanihara. That means that Shidehara's claims of communication problems are somewhat exaggerated. What was more decisive for the eventual outcome were Shidehara's true intentions when he rewrote Balfour's initial proposal.

In Shidehara's recollections, he stated that, in Balfour's proposal, 'the triple entente between Japan, the U.K., and the U.S. was close to an alliance, being understood as though it existed for the purpose of creating a political confederation'. For this reason, Shidehara surmised that the US would not accept it, given its traditional reticence towards forming alliances. Further, Shidehara interpreted the instructions he received from Foreign Minister Uchida as indicating that if Japan were to press strongly for the continuation of the alliance, then it may end up simply troubling the British government; it might be fruitless, yet also undignified. ${ }^{144}$

Following this understanding, Shidehara:

\begin{abstract}
Removed the provisions concerning the creation of a type of political confederation similar to an alliance from the triple entente proposal by the British chief delegate, and created a provision that stipulated the holding of conferences between the signatory nations whenever the need arose. What [I] created was a new proposal that replaced a treaty of alliance with something that more closely resembled a consultative pact. ${ }^{145}$
\end{abstract}

Although Shidehara was confined to his bed due to his sickness, he had this proposal shown to Balfour, who agreed to the basic approach before making his own revisions. Once Saburi showed this revised proposal to Hughes, Hughes argued that France should also be included in the pact.

Hughes invited Balfour, Shidehara and the French chief delegate to his private residence, where he showed them his revised proposal, along with an added preamble and a clause stating when it would come into effect. Due to circumstances such as the details of this proposal having been leaked to the Jiji Shinposha Shimbun newspaper company, the Four-Power Treaty would be quickly signed by the participating nations. 
The French chief delegate, however, became flustered as a result of this haste. Because approval from his home government did not arrive in time for the signing ceremony, he had to put off adding his own signature until a later date. This was perceived as a slight to France's pride as a major power. According to Shidehara, Hughes added France to the treaty because he wished to exploit Americans' affinity with France; this feeling had been fostered with French General Ferdinand Foch's visit to the US. ${ }^{146}$

If the intention was to prioritise the easing of tensions between the US and Japan, then Shidehara's approach was not mistaken. And, indeed, this was exactly what Shidehara hoped for. Hughes had been on edge at the idea of a renewal of the Anglo-Japanese Alliance. And even the UK, if it came to a standoff between Japan and the US, would have been highly unlikely to have sided with Japan. Given this reality, the potential for continuing the Anglo-Japanese Alliance remained limited. ${ }^{147}$

\section{Honest Diplomacy-Tranquil Public Relations}

Yet, we might ask, would an ambassador of lesser talents have come to the conclusion that the US would not readily agree to a proposal that included the effective continuation of the Anglo-Japanese Alliance? In fact, I suggest, what we should focus on regarding the above process is what it tells us about Shidehara's diplomatic technique. It can be argued that Shidehara had a tendency to look too far ahead, due to the importance with which he viewed Japan's relationship with the US. When Shidehara made his alterations to the proposal, was he not actually putting into practice the method of 'honest diplomacy' as the first principle in building a relationship of trust? To put it differently, I suggest that Shidehara sought to anticipate the possible US reaction to such a degree that he ended up proposing something that was already a compromise. Supporting this interpretation are the memoirs of Ishii Itarō. According to Ishii, 'Shidehara's conviction was that the most important thing needed for diplomacy is sincerity'. ${ }^{148}$

In general, the art of diplomatic negotiation cannot simply be to proceed according to your anticipation of what another nation wants. There are also times when it is necessary to take the opposite tack, to argue from a position that is initially removed from a point of possible compromise. This is something that Shidehara should have learned from the experience that Denison shared with him concerning the start of the Russo-Japanese War. Apparently, a degree of cunning was a part of Denison's legacy that 
Shidehara did not attempt to emulate. This is why the Four-Power Treaty was agreed upon so hastily. Even if the Anglo-Japanese Alliance was to be abolished, it should have been possible to do so using a different approach. By giving the impression, for example, that it was foreign pressure from the US that caused the end of the alliance, it may have been possible to instil in the minds of the citizenry that Japan and the UK were natural allies. Yet Shidehara decided not to take this route.

In any case, some noteworthy developments also occurred later regarding the Washington Naval Conference. First, Japan's diplomatic telegrams were decoded by the US. This fact was not revealed until 10 years after the conference, in 1931. In later years Shidehara would recall, 'I could not quite help smiling in satisfaction at the idea that because of the stolen codes, the U.S. must have taken Shidehara to be an unimaginative, honest man'. ${ }^{149}$ Although Shidehara felt a degree of bitterness regarding this development, it was certainly true that he had faith in the importance of honest diplomacy.

Thus, the Anglo-Japanese Alliance, once the cornerstone of Japanese diplomacy, finally came to an end. At this time, Foreign Minister Uchida confessed that he was 'strongly missing the Anglo-Japanese Alliance and reminiscing about the past'. ${ }^{150}$ It was not only the Japanese who regretted the termination of the alliance. Along with Balfour, UK Ambassador to Japan Charles N. E. Eliot, also deplored the alliance's passing. Meanwhile, George Sansom, then a commercial counsellor at the British embassy in Japan, later asserted that if the alliance had continued, Japan may well have avoided heading down the extreme path it took in subsequent decades. However, not everybody was displeased with this outcome. For one thing, it is true that for some time the UK's Foreign Office had many criticisms of the Anglo-Japanese Alliance. ${ }^{151}$

On the other hand, in the case of the US, a very interesting comment was made by Eugene H. Dooman, first secretary at the US embassy in Japan. Dooman expressed doubt as to whether, 'if the United States had not brought about the abrogation of the Anglo-Japanese Alliance, the character and temperament of the Japanese would have been what it was'. For Dooman, the Japanese 'resented very much the action of Great Britain in surrendering to American pressure in bringing that alliance to an end'. ${ }^{152}$ This episode suggests that ending an alliance is more challenging than establishing one. 
Yet, regardless of whether it was a necessary, a positive or a negative outcome, the Anglo-Japanese Alliance was abolished when the FourPower Treaty was formed. It should also be noted that Shidehara was successful in excluding the Japanese home islands from the scope of the new treaty. The reason for this exclusion was that the Japanese citizenry broadly felt that applying the treaty to Japan itself would be a national disgrace. Therefore, following the receipt of new orders after the signing of the Four-Power Treaty, Shidehara drafted and received approval for an additional agreement to be attached to the original, which outlined the exception with respect to the Japanese home islands. ${ }^{153}$

The honest diplomacy that Shidehara envisioned would also appear in material read by the general public. Starting from his time as viceminister for foreign affairs, Shidehara kept his distance from newspapers. According to Baba Tsunego, a journalist for the Kokumin Shimbun, 'even if [Shidehara] would sometimes meet with [the press], he would only answer one question in 10 posed to him by the newspaper reporters'. However, 'whenever he answered a question with a straight 'yes' or 'no', he would never lie'. ${ }^{154}$

This was not to say that Shidehara was entirely uninterested in communicating with the public. Meanwhile, a turning point in public relations and Japanese diplomacy took place during the Paris Peace Conference. Despite the fact that Japan had taken over Germany's former interests at the conference, a commonly expressed view was that Japan had lost to China in advertising. This negative experience was a major motive behind the eventual formal establishment, in 1921, of the Intelligence Department inside the head office of Japan's Ministry of Foreign Affairs. According to Ishii Kikujirō, however, 'if you try to look back at what kind of results the Intelligence Department actually achieved, there is nothing in particular that catches the eye. ${ }^{155}$

In fact, while serving as ambassador to the US, Shidehara had established his own Intelligence Department within the embassy, in the period before the Washington Naval Conference. Shidehara also invited Frederick Moore to assist as adviser for public relations. Moore was recommended to Shidehara by Hiroshi Saitō. ${ }^{156}$ Meanwhile, the press unit was also established at the time of the Naval Conference, and Counsellor Debuchi was dispatched from Germany to head the public relations section. From the beginning, Debuchi would be a plenipotentiary attendant, and Moore also later received this status. Shidehara himself once asserted to 
a Washington newspaper reporter-while referring to Article 4 of the Anglo-Japanese Alliance-that 'it is next to impossible that Japan and the U.K. would assist the other in a joint strategy if their opponent was the United States'. ${ }^{157}$ On another occasion he explained Japan's position in a magazine owned by the New York Times. Shidehara also sought to foster a friendly relationship with Thomas William Lamont, who was US representative at the time of the New Four-Power Consortium. ${ }^{158}$

Nevertheless, Shidehara struggled when it came to dealing with Japanese newspapers. In his view, they were still far too underdeveloped and insincere compared to their counterparts in the UK and the US. He was particularly nervous when a draft proposal of the Four-Power Treaty was leaked to the Jiji Shinpo. In his memoirs, Shidehara asserted that the draft found its way into the hands of the papers' special correspondent, Itō Masanori. Although there was some suspicion that it was Plenipotentiary Tokugawa who shared the draft with the Jiji Shinpo, the truth of the matter was never revealed. ${ }^{159}$

Incidents such as the one above help cast light on how Shidehara understood public relations. For Shidehara, public relations did not constitute the axis of diplomacy. On the contrary, there was now so much propaganda being produced that it could only damage Japan's relationships with other nations. In his view, it was enough if Japan's true nature and intentions were 'correctly' conveyed. In other words, Japan needed to promote itself and its interests in a 'tranquil' manner. Even if China were content to pursue 'propaganda diplomacy', Japan should not follow suit. While Japan's subsequent efforts in creative public relations were more modest, Shidehara gradually came to appreciate their effectiveness. ${ }^{160}$ Yet, he continued to believe that what was essential was not public relations but negotiations themselves and the relationships of trust upon which they relied. Any other approach, in Shidehara's opinion, was putting the cart before the horse.

\section{Returning to Japan - the Great Kantō Earthquake}

With the conclusion of the Washington Naval Conference, Shidehara returned to Japan for medical treatment in April 1922. Counsellor Saburi would serve as acting ambassador until February of the following year. Back in Japan, Shidehara spent his time in convalescence, reading and thought. Yet, this stay was interrupted by an unexpected disaster: the Great Kantō Earthquake of September 1923. Following the earthquake, a large 
amount of aid was sent to Japan from the US. Surprisingly, the US was concerned that the Japanese people might be insulted if they thought they were being treated as an object of charity. For this reason, banker Thomas W. Lamont, of J. P. Morgan \& Co., reached out to Finance Minister Inoue Junnosuke (1869-1932) of the Yamamoto cabinet to impress upon the Japanese government that US aid to Japan was being given with no ulterior motive. $^{161}$

On the day of the earthquake, Shidehara was in Osaka. In his reflections on this time, he stated that, while passing between Nagoya and Nagano on his way back to Tokyo, he helped some Koreans who were being harassed. Unfortunately, the residence that Shidehara had purchased in the Surugadai district, near central Tokyo, was lost in the fires that followed the earthquake. Most of the several thousand books from Denison's old library were turned to ash. Shidehara wrote that the few books that survived 'were later also destroyed when my residence in Sendagaya was damaged in bombing in the spring of the twentieth year of Shōwa [1945]. So [in the end] not a single volume remained'. He added: 'Whenever I think back on this loss, I am overwhelmed by emotion'. ${ }^{162}$

Following the earthquake, the Shidehara household received support from the Iwasaki family (who, it should be recalled, were the founders of the Mitsubishi financial conglomerate, and Shidehara's wife Masako's original family). The Iwasaki family bestowed on the Shidehara household the Rikugien garden in Komagome, which was to serve as a new residence. Rikugien was a famous garden in Tokyo from the Edo period. Shidehara moved there a few months before his appointment as foreign minister. At the time, however, Shidehara was not particularly looking forward to serving as foreign minister.

On this topic, we have testimony from Ishii Itarō. During Shidehara's time as ambassador to the US, Ishii once happened to sit beside him in a railway car. Ishii took the opportunity to attempt to draw Shidehara out a little concerning his upcoming appointment as foreign minister. Shidehara, however, responded curtly: 'No, no, I'm not fit to be foreign minister'. Reflecting upon his time as vice-minister for foreign affairs, he confided in Ishii that, because 'the Japanese political world is truly quite complicated, a person like me is simply not cut out to be foreign minister'. In particular, Shidehara considered the Privy Council and the political parties to be simply too difficult for him to handle. Yet, despite Shidehara's reservations, in June 1924 he became foreign minister. 
The next time he met Ishii, Shidehara greeted him with a wry smile. 'I didn't want to become foreign minister; that's just when they went and made me one. ${ }^{\prime 163}$

\section{Four Points in a Quarter Century}

This initial chapter has traced Shidehara's career path up to the moment that he assumed this important position. As noted earlier, this chapter sought to cover four main topics regarding this quarter century. Its findings are summarised below.

The first topic concerned the formation of Shidehara's thinking. Shidehara's ideal was British-style diplomacy. Here the influence of James Bryce and Sir Edward Grey was particularly significant. This does not mean, however, that Shidehara's policies were necessarily pro-British, as shown by Shidehara's initiative in abolishing the Anglo-Japanese Alliance.

While Shidehara also stayed in the US for a long time, he did not encounter an individual comparable in stature with Bryce or Grey. He was uncomfortable with the foreign policy ideals of President Wilson and considered Bryan a diplomatic novice. Shidehara's relationship with Lansing was also strained, as evidenced from the proceedings of the Paris Peace Conference and the manner in which the US withdrew its troops from the Siberian Intervention. Shidehara was further aware, along with Foreign Minister Uchida, that behind the scenes of the negotiations surrounding a New Four-Power Consortium was a plan to secretly expand railways such as the Manchurian Railway into a continental railway. In the final phase of the New Four-Power Consortium negotiations, Shidehara strove to do his utmost as ambassador to the US to protect Japan's interests in China. ${ }^{164}$

That said, more than a few of Shidehara's policies were actually favourable towards the US. As vice-minister for foreign affairs, Shidehara had worked to restrain the Japanese army during the Siberian Intervention, while at the Washington Naval Conference he proactively adopted open door policy positions. Therefore, while it is certainly the case that British-style diplomacy represented Shidehara's ideal, when it came to the concrete actions he took as a diplomat in this period, if anything, he was in closer alignment with the US. Shidehara understood that diplomatic ideals and the Japanese national interest were separate affairs. 
As I have shown in this chapter, however, Shidehara's interpretation and application of an open door policy deserves closer scrutiny. Shidehara understood the open door provision of the Nine-Power Treaty in a restricted manner. For him, it referred primarily to equality of opportunity, that is, the sense of the term that Hay deployed in his first note. In other words, Shidehara was strictly opposed to any third nation intervening politically in China. This is why Shidehara, despite being on fairly congenial terms with Hughes, stood firmly against international management of the Chinese Eastern Railway. Meanwhile, when Hughes attempted to establish an open door policy investigative body, Shidehara ensured that it was as toothless as possible.

In summary, while Shidehara accepted a form of open door policy, he interpreted and applied that policy in a restricted sense to protect Japan's interests on the Chinese continent. By accepting an open door policy as an ideal, Shidehara was able to use it to protect the reality of a defence of national interests in China. It should be kept in mind that Shidehara did not think that having an open door policy was only an ideal of US diplomacy. According to Shidehara, Japan's pursuit of such a policy was a development that arose in the wake of the Anglo-Japanese Alliance, the Treaty of Portsmouth and the Franco-Japanese Treaty. This is another instance where the influence of Denison is visible. I have further noted in this chapter that Shidehara also saw the annexation of Korea as a natural development. It was also Shidehara who oversaw the removal of import duties on Korean rice after the annexation. We can see, therefore, how the open door principle was already understood in a restricted sense in this early period. If we also take into consideration the interpretation of the Korean provision in the Treaty of Portsmouth, then what emerges is a picture whereby pursuit of the open door principle, understood in a limited sense, actually helped to support the development of the Japanese empire.

We have also seen how the locus of Shidehara's direct experience of Asia was Korea and not China. It was not until his time as vice-minister for foreign affairs that he would need to seriously confront issues surrounding China. Later, as ambassador to the US, he would take the lead directly and demonstrate that he was as good as anyone in dealing with Chinese issues on a broad basis. Yet he tended to be overly theoretical. Later diplomats such as Yoshida Shigeru, Arita Hachirō and Shigemitsu Mamoru were frequently richer in experience with regard to China. 
Finally, with respect to the formation of Shidehara's thinking, two more details should be kept in mind. First, I noted that Shidehara greatly admired Washburn's book Nogi and recommended its translation to an old school colleague. Second, I pointed out that Shidehara was apprehensive about the crown prince visiting the US.

The second main topic explored in this chapter was that of Shidehara's diplomatic style. If it could be said that Shidehara had a formative experience, then that would be his witnessing of the commencement of the Russo-Japanese War while stationed in Busan. It was there that he was baptised in the conduct of 'power politics', which is based on the deployment of military power. Shidehara was also not squeamish about gunboat diplomacy and its attendant use of force. His later meeting with Denison, however, would be a turning point. It was thereafter that Shidehara would acquire a thorough knowledge of international law. It was also from Denison that he would hear behind the scenes anecdotes about the diplomacy relating to the commencement of the Russo-Japanese War.

Yet, despite the inside knowledge Shidehara acquired of how to conduct diplomatic negotiations, he did not simply follow the model set for him by Denison. Rather, Shidehara tried to follow the path of 'honest diplomacy', which he saw as the first principle in building relationships of trust with other nations. Shideharas thinking in this regard is shown in the way he handled public relations and the termination of the Anglo-Japanese Alliance at the Washington Naval Conference. At that conference, Shidehara even took the initiative in seeking a resolution to the Far East problem.

We can better understand Shidehara's 'honest diplomacy' by contrasting it with the approach of Katō Takaaki. In his Twenty-One Demands issued to China, Foreign Minister Katō included Group 5 (the last and most aggressive set of demands) as leverage for subsequent negotiation. It was included without the expectation that the Chinese would acquiesce to it. In other words, Katō was here pursuing British-style imperialist diplomacy. This method would also be deployed by figures such as Foreign Minister Komura. From Katō's perspective, therefore, the TwentyOne Demands must have seemed fairly reasonable at the time of their conception. Yet the Wilson administration sought a more moral approach to international relations and reacted negatively to the Twenty-One 
Demands. Katō's approach therefore complicated affairs significantly for Japan. ${ }^{165}$ It is reasonable to assume that Shidehara would have learned from the failure of Katō's diplomatic efforts here.

It was at just this time that the status of the European powers was beginning to decline, relative to the rise of the US. Shidehara's response to this new global reality was to take the initiative in abolishing the Anglo-Japanese Alliance and in pursuing an open door policy with respect to the Far East. This diplomatic style helped to establish Shidehara's name internationally. It was also a style that was particularly compatible with the US.

The third topic I examined was Shidehara's personal connections. I noted that, at first glance, Shidehara and Komura's personalities appear to have been diametrically opposed. However, Shidehara's concrete actions show that, along with individuals such as Moroi Rokurō, he actually supported Komura's efforts at treaty revision. It must be added that Shidehara was not a fervent adherent to the view that Japan ought to become the future leader of East Asia. In this sense, therefore, Shidehara certainly was not Komura's successor. I also pointed out that during his time as counsellor at the Japanese embassy in the US, Shidehara greatly respected Ambassador Chinda for his ability to go head-to-head in debating Secretary of State Bryan.

As vice-minister for foreign affairs, Shidehara flawlessly served five consecutive foreign ministers: Ishii Kikujirō, Terauchi Masatake, Motono Ichirō, Gotō Shinpei and Uchida Yasuya. It was under Foreign Minister Motono that Shidehara would take on the burden of formulating policy with respect to China. Shidehara's relationship with Hara Takashi, meanwhile, was not exactly good at the outset. Yet he was gradually able to earn Hara's trust.

As ambassador to the US, Shidehara made Debuchi Katsuji his righthand man. Once Debuchi left the embassy for a new role, Shidehara would place greater trust in Saburi Sadao, rather than Hirota Kōki. I have suggested that when it came to dealing with important issues, Shidehara preferred to work with subordinates whom he could trust. Shidehara's close-knit relations with Debuchi and Saburi during his time as ambassador can actually be regarded as the origin of what would later be the 'Shidehara clique'. These connections would later come to the fore once he assumed the office of foreign minister, as we shall see in more detail at the beginning of Chapter 3 . 
The fourth and final topic for consideration was the impact that Shidehara had on how other foreign nations, and, in particular, the US, viewed Japan. Certainly, Shidehara gained a degree of international fame for his efforts during the Washington Naval Conference. A product of this conference was the formation of a cooperative international order that centred on Japan, the US and the UK. In academic circles this would be called the Washington System. The greatest personification of the diplomatic approach symbolised by the Washington System was Shidehara himself.

That said, the tide still did not turn fully in favour of the US cooperating with Japan. A tendency to favour China, visible in the speech and actions of Williams, was also adopted in the State Department by individuals such as Johnson and Hornbeck. It would not be until the conference in London to sign the Treaty for the Limitation and Reduction of Naval Armament-during Shidehara's second stint as foreign ministerthat a pro-Japanese force would begin to form on the US side, making it possible for Japanese diplomats to begin exploring how to build a relationship with them.

\section{Endnotes}

1 This chapter is based on my previously published article. See Hattori Ryūji, 'Meiji Taishō-ki no Shidehara Kijūrō' [Shidehara Kijūrō in the Meiji and Taishō periods], Chūō Daigaku Ronshū, no. 25 (March 2004): 1-41.

2 Ōno Katsumi, 'Meiji Gaikō to Denison Komon no Kenshin' [Meiji diplomacy and the dedication of Advisor Denison], Bungei Shunjū 44, no. 11 (November 1966): 180-88; Ministry of Foreign Affairs Hundred-Year History Compilation Association, ed., Gaimushō no 100 Nen [A hundred years of the Ministry of Foreign Affairs], vol. 2 (Tokyo: Harashobō, 1969), 1341-47; Ichimata Masao, Nihon no Kokusai Hōgaku wo Kizuita Hitobito [The builders of Japan's international law] (Tokyo: Japan Institute of International Affairs, 1973), 58-59; Takeuchi Haruhisa, 'Denison-zō to Meiji no Omokage' [A portrait of Denison and the remnants of the Meiji era], Gaikō Forum, no. 171 (2002): 76-81; Takeuchi Haruhisa, 'Kieta Denison Shōzōga' [A vanished portrait of Denison], Gaikō Forum, no. 172 (2002): 82-87.

3 Valuable insights on this point are available in Matsumura Masayoshi, 'Washington Kaigi to Nihon no Kōhō Gaikō’ [The Washington Naval Conference and Japanese public diplomacy], Gaimushō Chosa Geppō, no. 1 (June 2002): 47-76. See also Matsumura Masayoshi, Shinpan Kokusai Kōryū-shi: Kingendai Nihon no Kōhō Bunka Gaikō to Minkan Köryū [History of international exchange: Modern Japanese public and cultural diplomacy and its connection with civilian exchange], 2nd ed. (Tokyo: Tajinkan, 2002).

4 Hattori Ryūji, Higashi Asia Kokusai Kankyō no Hendō to Nihon Gaikō, 1918-1931 [Japanese diplomacy and East Asian international politics, 1918-1931] (Tokyo: Yūhikaku, 2001), 89-112.

5 Hayashi Gonsuke, Waga 70 Nen wo Kataru [Speaking of my 70 years], ed. Iwai Takahito (Tokyo: Daiichi Shobō, 1935), 65.

6 Shidehara Kijūrō, 'Senpai toshiteno Ijūin-Dan' [My senior, Baron Ijūin], in Ijūin HikokichiDan, General Aoki Nobuzumi Tsuitō-roku [Tribute to Baron Ijūin Hikokichi and General Aoki Nobuzumi], ed. Memorial Service Initiator (Tokyo: Memorial Service Initiator, 1934), 28-30. 
7 Shidehara Kijūrō, 'Senpai toshiteno Ijūin-Dan' [My senior, Baron Ijūin], in Ijūin Hikokichi-Dan, General Aoki Nobuzumi Tsuitō-roku [Tribute to Baron Ijūin Hikokichi and General Aoki Nobuzumi], ed. Memorial Service Initiator (Tokyo: Memorial Service Initiator, 1934), 28-30; Nagai Matsuzō, 'Shidehara Danshaku no Omoide' [Memories of Baron Shidehara], 16 June 1952, in 'Shidehara Heiwa Bunko', Reel 13; Shidehara, Gaikō 50 Nen, 35-36.

8 Shidehara, Gaikō 50 Nen, 13-15.

9 Tonedachi Masao, ed., Nihon Gaikō Hiroku [Confidential records of Japanese diplomacy] (Tokyo: Asahi Shimbunsha, 1934), 87.

10 For an overview of these doctrines along with a critique, see Chiba Isao, 'Man-Kan FukabunRon = Man-Kan Kōkan-Ron no Keisei to Takakuteki Dōmei, Kyōshōmō no Mosaku [The formation of the Man-Kan Fukabun Doctrine as equivalent to the Man-Kan Kōkan Doctrine, and the search for a multilateral alliance or entente], Shigaku Zasshi 105, no. 7 (July 1996): 38-73; Chiba Isao, 'NichiRo Senzen-ki [1900-04]: Gaikō-shi Kenkyū no Jōtai' [The pre-Russo-Japanese War era [1900-04]: The current state of diplomatic history research], Shigaku Zasshi 106, no. 8 (August 1997): 87-103.

11 Hayashi to Mutsu (in Maiko), 23 April 1895, in Nihon Gaikō Bunsho [Documents on Japanese foreign policy], ed. Ministry of Foreign Affairs, vol. 28, no. 2 (Tokyo: United Nations Association of Japan, 1963), 14-17.

12 Mutsu Munemitsu, Shintei Kenkenroku [A record of tribulations], 2nd ed., annotated Nakatsuka Akira (Tokyo: Iwanami Shoten, 1983), 302.

13 Hayashi Tadasu, Nochi wa Mukashi no Ki, Hoka: Hayashi Tadasu Kaikoroku [Records of the past, other: Memoirs of Hayashi Tadasu], ed. Yui Masaomi (Tokyo: Heibonsha, 1970), 66-83, 261-383.

14 Shidehara Kijūrō, 'Gaikō Kanken' [My views on diplomacy], 9 October 1928, in 'Shidehara Heiwa Bunko', Reel 7. See also Hattori Ryūji, 'Shidehara Kijūrō (lecture), "Gaikō Kanken”' [My views on diplomacy], Sōgō Seisaku Kenkyū, no. 13 (March 2006): 99-112.

15 Shidehara, 'Gaikō Kanken'.

16 Ibid.

17 Tashiro Kazui, Wakan: Sakoku Jidai no Nihonjin-machi [Wakan: Japanese town of the age of national isolation] (Tokyo: Bungei Shunjū, 2002).

18 Governor-General of Korea Railway Bureau, Chōsen Tetsudō-shi [The history of railways in Korea] (Seoul: Governor-General of Korea Railway Bureau, 1915), 61-112, 163-91; Nihon Yūsen, ed., Nihon Yüsen Kabushiki Gaisha 50 Nen-shi [A 50-year history of Nihon Yusen co.] (Tokyo: Nihon Yūsen, 1935), 133; Tani Hisao, Kimitsu Nichi-Ro Sen-shi [Secret history of the Russo-Japanese War] (Tokyo: Harashobō, 1966), 108; Kimura Kenji, Zaichō Nihonjin no Shakai-shi [The social history of Japanese residents in Korea] (Tokyo: Miraisha, 1989), 75, 81-83; Kokaze Hidemasa, Teikokushugika no Nihon Kaiun: Kokusai Kyōsō to Taigai Jiritsu [Japanese shipping in the age of imperialism: International competition and independence from abroad] (Tokyo: Yamakawa Shuppansha, 1995), 229-58; Takahashi Yasutaka, Nihon Shokuminchi Tetsudō-shi Ron [Discourse on railways in the Japanese colonies] (Tokyo: Nihon Keizai Hyōronsha, 1995), 61-65.

19 Japanese National Railways, Hiroshima Railway Management Bureau, Kanpu Renrakusen-shi [A history of the ferry service between Shimonoseki and Busan] (Tokyo: Japanese National Railways, Hiroshima Railway Management Bureau, 1979), 18.

20 Iwasaki Yatarō, Iwasaki Yanosuke Biography Editing Association, ed., Iwasaki Yatarō Den [A biography of Iwasaki Yatarō], vol. 2 (Tokyo: Iwasaki Yanosuke Biography Editing Association, 1967), 619-21. For more detailed information on the beginning of the relationship between Shidehara and Masako, see Kishi Kuramatsu, Ko-Shidehara Kijūrō-shi no Omoide wo Kataru [Memories of Late Mr. Shidehara Kijūrō], 19 July 1952, in 'Shidehara Heiwa Bunko', Reel 13.

21 Shidehara is not the only example of a diplomat receiving a marriage offer in this manner. In fact, it was customary for diplomats to use marriage to align their families with those of powerful people and other diplomats. Examples include Sawada Miki-the wife of Japan's delegate to the United Nations in the postwar era Sawada Renzō_-was the eldest daughter of Iwasaki Hisaya, who in turn was the eldest son of Iwasaki Yatarō. Diplomat Sawada Setsuzō—-the elder brother of diplomat 
Sawada Renzō— was the son-in-law of Ōyama Tsunasuke, Japan's ambassador to Italy. He would later occupy posts such as Japan's secretary general at the League of Nations. It is also well known that Yoshida Shigeru was the son-in-law of Makino Nobuaki. Saburi Sadao, who would eventually die under suspicious circumstances as Japan's minister to China, was the son-in-law of Komura Jutarō. Yoshizawa Kenkichi was the son-in-law of Inukai Tsuyoshi and served as the foreign minister in the Inukai cabinet. At the outset of the Pacific War, the counsellor to Japan's embassy in the US, Iguchi Sadao, became Yoshizawa Kenkichi's son-in-law. Okabe Nagakage-chief of the Department of Cultural Affairs with China-married Katō Takaaki's daughter. Debuchi Katsuji, who served as both vice-minister for foreign affairs and ambassador to the US, was Kikuchi Takeo's son-in-law; as a judiciary bureaucrat, he became both chairman for the Tokyo Bar Association and president of Chūō University. Debuchi's eldest daughter, Takako, married Asakai Kōichirō, who served as an ambassador to the US for five years and 10 months, exceeding Debuchi's tenure of five years and two months.

For further details, see the following works: Sawada Renzō, Gaisenmon Hiroba [Arch of Triumph Square] (Tokyo: Kadokawa Shoten, 1950), 85-57, 129-32; Sawada Renzō, Zuikan, Zuihitsu [Miscellaneous impressions] (Tokyo: Makino Shuppan, 1990), i; Iwasaki Family Bibliographical Publishing Association, ed., Iwasaki Hisaya Den [A biography of Iwasaki Hisaya] (Tokyo: University of Tokyo Press, 1979), 580; Sawada Toshio, ed., Sawada Setsuzō Kaisōroku: Ichi Gaikōkan no Shōgai [Memoirs of Sawada Setsuzō: The life of a diplomat] (Tokyo: Yūhikaku, 1985), 2, 16-18, 23, 26, 52, 127, 159, 218, 220, 221, 296; Kurogi Yūkichi, Komura Jutarō (Tokyo: Kōdansha, 1968), 948; Nakano Keishi, ed., Yoshizawa Kenkichi Jiden [The autobiography of Kenkichi Yoshizawa] (Tokyo: Jiji Tsūshinsha, 1964), 57-58, 61-62; Shōyū Society Incorporated, ed., Okabe Nagakage Nikki: Shöwa Shoki Kazoku Kanryō no Kiroku [The diary of Okabe Nagakage: Records of an early Shōwa-era aristocratic bureaucrat] (Tokyo: Kashiwa Shobō, 1993), 626-27; Arai Yōtarō, ed., Kikuchi Sensei Den [A biography of Kikuchi Sensei] (Tokyo: Ōzorasha, 1997), 2-3, 170-73; Takahashi Katsuhiro, ed., “'Debuchi Katsuji Nikki” (7) Kan: Kaikodan, Shuyō Chosaku Ichiran, Kankei Keizu, Shuyō Jinmei Sakuin' [The diary of Debuchi Katsuji (7) complete: Reminiscences, overview of major works, genealogical tables, index of major figures], Kokugakuin Daigaku Nihonbunka Kenkyūjo Kiyō, no. 90 (September 2002): 340-41; Asakai Kōichirō, Tsukasamachi Kanwa: Ichi Gaikōkan no Kaisō [Quiet talk in Tsukasamachi: Recollections of a diplomat] (Tokyo: Asakai Kōichirō Memoir Editorial Group, 1986), 300.

A few more examples are Inoue Katsunosuke — minister to Germany and ambassador to the UK-was the adoptive heir of Inoue Kaoru. Yamagata Isaburō, who served as governor-general of Kwantung, was the adoptive heir of Yamagata Aritomo. Satō Naotake, who became foreign minister in the Hayashi cabinet, was the adopted child of Satō Aimaro-ambassador to the US. Chinda Sutemi, who married Aimaro's younger sister, became ambassador to the US. In addition, Ishii Kikujirō was the adopted child of Mie prefectural governor Ishii Kunimichi. Kubota Kanichirō was the son-in-law of Ishii Kikujirō, while Shiratori Toshio was Ishii's nephew. Setsuko, eldest daughter of Matsudaira Tsuneo-who served as vice-minister for foreign affairs, ambassador to the US, ambassador to the UK and minister of the imperial household—married Yasuhito (Prince Chichibu), becoming Princess Chichibu.

For details on the above, see: Marquis Inoue Kaoru Biography Editing Association, ed., Köshaku Inoue Katsunosuke Kun Ryakuden [A short biography of Marquis Inoue Katsunosuke] (Tokyo: Naigai Shoseki, 1934), 2; Tokutomi Iichirō, ed., Sokū Yamagata Kō Den [The biography of Duke Sokū Yamagata] (Tokyo: Duke Yamagata Biography Editing Association, 1929), 13; Tokutomi Sohō, ed., Köshaku Yamagata Aritomo Den [The biography of Duke Yamagata Aritomo], vol. 2 (Tokyo: Harashobō, 1969), 1036; Satō Naotake, Kaiko 80 Nen [Looking back on 80 years] (Tokyo: Jiji Tsūshinsha, 1963), 56-57; Kikuchi Takenori, ed., Hakushaku Chinda Sutemi [Count Chinda Sutemi] (Tokyo: Kōmeikaku, 1938), 319; Kajima Peace Research Center, ed., Ishii Kikujirō Ikō: Gaikō Zuisō [The posthumous manuscripts of Ishii Kikujirō: Diplomatic reflections] (Tokyo: Kajima Research Center Press, 1967), prologue, 363; Tokyo PR News Service, Matsudaira Tsuneo Tsuisōroku [Recollections of Matsudaira Tsuneo] (Tokyo: Late Matsudaira Tsuneo Memorial Association, 1961), 7-8, 726.

Given such family connections, it was inevitable that these elite bureaucratic graduates of the Imperial University of Tokyo saw themselves as a special group within Japanese society. Similar to Sugimura Fukashi and Sugimura Yōtarō, there were also cases where both parent and child were diplomats. For example, Komura Jutarō and his eldest son, Komura Kinichi, were both diplomats, and Arita Hachirōs third son, Arita Keisuke, became vice-minister for foreign affairs in the latter half of the 1970s. 
22 Shidehara to Foreign Minister Komura, 8 February 1904, in Nikkan Gaikō Shiryo Shüsei [Compilation of material concerning Japan-Korea diplomacy], ed. Kamikawa Hikomatsu and Kin Seimei, vol. 5 (Tokyo: Gannandō, 1967), 45; Shidehara Kijūrō, 'Busan Ryōji Jidai no Ōtegara' [The high achievements of the Busan Consul era], in Sono Koro wo Kataru [Recalling those times], ed. Tonedachi Masao (Tokyo: Tokyo Asahi Shimbunsha, 1928), 222-27.

23 Ministry of Foreign Affairs, ed., Nihon Gaikō Nenpyō narabini Shuyō Bunsho [Chronology and main documents of Japanese diplomacy], vol. 1 (Tokyo: Harashobō, 1965), 222; Komura to Shidehara, 10 February 1904, in Kamikawa and Kin, Nikkan Gaikō Shiryo Shüsei, vol. 5, 55-56.

24 Shidehara to Komura, 21 January 1904, in Nihon Gaikō Bunsho: Nichi-Ro Sensō [Documents on Japanese foreign policy: The Russo-Japanese War], ed. Ministry of Foreign Affairs, vol. 4 (Tokyo: Ministry of Foreign Affairs, 1960), 347; Komura to Shidehara, 21 January, ibid., 347; Shidehara to Komura, 9 February, ibid., 350-51; Shidehara to Komura, 20 February, in Kamikawa and Kin, Nikkan Gaikō Shiryo Shüsei, vol. 5, 67; Hayashi, Waga 70 Nen wo Kataru, 182-85.

25 Ministry of Foreign Affairs Hundred-Year History Compilation Association, Gaimushō no 100 Nen, vol. 1, 257.

26 'Hon-shō Yatoi Denison Yakujōsho' [Written contract employing Denison at this ministry], 1 March 1880, in 'Gaimushō Gaikokujin Yatoiire Ikken (Fu-Keiyakusho) Bessatsu “Denison”-shi Kankei' [Ministry of Foreign Affairs foreigner employment case (contract attached) separate volume, relating to Mr Denison], 3.9.3.7-1, Diplomatic Archives of the Ministry of Foreign Affairs of Japan; Toyabe Shuntei, 'Denison', Taiyō 11, no. 1 (January 1905): 35-38. According to Aoki Shūzō, Foreign Minister Ōkuma Shigenobu often relied on Denison to amend the unequal treaties. See Aoki Shūzō, Aoki Shüzō Jiden [The autobiography of Aoki Shūzō], ed. Sakane Yoshihisa (Tokyo: Heibonsha, 1970), 155-56.

27 Shidehara, Gaikō 50 Nen, 246-53; Kajima Peace Research Center, Ishii Kikujirō Ikō, 325-26.

28 Shidehara Kijūrō, 'Gaikō Bunsho no Buntai, Kisōsha no Kokoroe narabini Shoshu no Keishiki' [Writing style for diplomatic documents, important knowledge for drafters, different types of forms], April 1940, in Kindai Gaikō Kaikoroku [Modern diplomatic memoirs], ed. Hirose Yoshihiro, vol. 4 (Tokyo: Yumani Shobō, 2000), 83-94.

29 Ibid.

30 For example, in official documents, the address entry was normally followed by the sender's signature. When the document was intended to be friendly, senders referred to themselves in the first person. For more serious documents, third person might be used. For verbal notes, important proposals were directly delivered by hand. In such cases, there was no need for an address or for the sender to provide a signature, and the sender was referred to in the third person. Memoranda included detailed notes on facts related to the items being negotiated. Here, too, both the address and sender's signature were omitted, and the third person was used to identify participants in the negotiations. Later, Shidehara would record Denison's instructions so that other ministry staff could use them.

31 Shidehara Kijūrō, 'Kaisō no Paris Heiwa Kaigi' [My recollections of the Paris Peace Conference], Kaizō (February 1950): 72-74. See also Shidehara, Gaikō 50 Nen, 20-30.

32 Ishii Kikujirō, Gaikō Yoroku [Diplomatic unofficial record] (Tokyo: Iwanami Shoten, 1930), 82-84; Ishii Kikujirō, Gaikō Kaisō Danpen [Some recollections of diplomacy], ed. Izumino Seiichi (Tokyo: Kinseidō, 1939), 6-7.

According to Mushanokōji, 'Shidehara-san no Omoide' [Memories of Mr Shidehara], date unknown, in 'Shidehara Heiwa Bunko', Reel 13:

Regarding this idea that Mr. Shidehara, of his own accord, decided to send a telegram regarding a matter that would have major significance for the nation, this is very difficult to believe, given Mr. Shidehara's personality, as well as the seriousness of the matter in question. I think it likely that Shidehara had misremembered this incident and that he had sent the telegram on the basis of instructions from his superior.

In fact, elsewhere Shidehara himself has been recorded as stating: 'With the southern half of Sakhalin Island, this was a result that followed from Mr. Ishii (and, of course, me) strongly urging Mr. Chinda to act'. See Shidehara Kijūrō, 'Nihon Gaikōkai no Omoide' [Memories of Japan's diplomatic world], ed. Kiyosawa Kiyoshi, 5 December 1944, in 'Shidehara Heiwa Bunko', Reel 7. 
Further, the following message was presented from Katsura to Kodama Gentarō, chief of the Office of Army General Staff for the Manchurian Army based in Mukden, in Ministry of Foreign Affairs, Nihon Gaikō Bunsho: Nichi-Ro Sensō, vol. 5, 302-03:

Because the government has received a secret report that the Russian Empire is prepared to transfer the southern half of Sakhalin, this information is to be urgently shared with the committee.

However, even Foreign Ministry records do not clarify the details of the corrections made to the telegram.

For more details on this, see Ministry of Foreign Affairs, ed., Komura Gaikō-shi [A history of Komura diplomacy] (Tokyo: Harashobō, 1966), 585; Okamoto Shumpei, The Japanese Oligarchy and the Russo-Japanese War (New York: Columbia University Press, 1970), 155; Shinobu Seizaburō and Nakayama Jiichi, eds, Kaiteiban Nichi-Ro Sensō-shi no Kenkyū [A study of the history of the RussoJapanese War], 2nd ed. (Tokyo: Kawade Shobō Shinsha, 1972), 412-14; Raymond A. Esthus, Double Eagle and Rising Sun: The Russians and Japanese at Portsmouth in 1905 (Durham: Duke University Press, 1988).

33 Yamaza Enjirō, 'Nichi-Ro Kowa ni Tomonau Manshū Mondai no Kyokusetsu' [Twists and turns of the Manchurian problem attending the Russo-Japanese peace settlement], August 1913, in Ministry of Foreign Affairs, Nihon Gaikö Bunsho: Nichi-Ro Sensō, vol. 5, 303-09. See also Hasegawa Takashi, Tairiku Gaikō no Senku Yamaza Kōshi [Minister Yamaza, pioneer of continental diplomacy] (Tokyo: Ikuseisha, 1938), 95-96.

34 Shidehara Kijūrō, 'Washington Kaigi no Rimen-kan Sonota' [Behind the scenes of the Washington Naval Conference and others], February 1939, in Hirose, Kindai Gaikö Kaikoroku, vol. 4, 132-35.

35 Ibid.

36 Ibid.

37 Ibid.

38 Ibid.

39 Takahira to Foreign Minister Katsura, 13 September 1905, in 'Nichi-Ro Kowa Jyōyaku Teiketsu Ikken (Komura Iin Byōki Kikoku) (Kōwa Seiritsu Shukuji) (Denpō Toriatsukai)' [Russo-Japanese Peace Treaty conclusion (representative Komura's homecoming for sickness) (congratulatory addresses for peace attainment) (handling of telegrams)], 2.2.1.3-2, Diplomatic Archives of the Ministry of Foreign Affairs of Japan.

40 Shidehara, 'Kaisō no Paris Heiwa Kaigi', 72.

41 Ibid.

42 Ibid. Shidehara's conversation outline (Komagome residence), 24 October 1933, in 'Shoshushi Kankei Zakken: Gaikō Shiryō Shūshū Kankei' [Miscellanea related to various historiography: Diplomatic relations materials collection], vol. 1, N.2.1.0.4-1, Diplomatic Archives of the Ministry of Foreign Affairs of Japan; with the same point found in Shidehara, Gaiko 50 Nen, 31-35. See also Komura Kinichi, 'Teito Kensō no Naka wo Chichi Kaeru' [The father returns in the bustle of Tokyo], in Sono Koro wo Kataru [Recalling those times], ed. Tonedachi Masao (Tokyo: Tokyo Asahi Shimbunsha, 1928), 246-52.

43 Hara Keiichirō, ed., Hara Takashi Nikki [The diary of Hara Takashi], vol. 2 (Tokyo: Fukumura Shuppan, 1981), 131-32, 143-45; Oka Yoshitake, Oka Yoshitake Chosaku-shū [The collected works of Oka Yoshitake], vol. 4 (Tokyo: Iwanami Shoten, 1993), 94.

44 Ministry of Foreign Affairs and Japan Society for the Promotion of Science, eds, Joyaku Kaisei Kankei: Nihon Gaikō Bunsho, Bessatsu, Tsushō Jōyaku to Tsüshō Seisaku no Hensen [Relating to treaty revision: Documents on Japanese foreign policy, separate volume, changes in commercial treaties and international trade policy] (Tokyo: World Economic Investigation Foundation, 1951), 5; Kubota Kiyochika, ed., Hagiwara Moriichi-shi Tsuikairoku [Remembering Mr Hagiwara Moriichi] (Tokyo: Hakubunkan, 1913), 10-11, 231-37. 
45 Kawashima Nobutarō, 'Shidehara Sōri heno Omoide: Jōyaku Kaisei' [Memories of Prime Minister Shidehara: Treaty revision], 1953, in 'Shidehara Heiwa Bunko', Reel 18. For Moroi’s memorandum, see Moroi Rokurō, 'Jōyaku Kaisei Iken' [An opinion on treaty revision], in Jōyaku Kaisei Ron Shiryō Shūsei [Treaty revision discourse complication], ed. Inō Tentarō, vol. 6 (Tokyo: Harashobō, 1994), 29-90. Kawashima Nobutarō's main work was Honpō Tsūshō Seisaku Jyoyaku-shi Gairon [Introduction to the history of Japanese trade policy treaties] (Tokyo: Ganshodō Shoten, 1941). It was also Kawashima who wrote Ministry of Foreign Affairs et al., Jōyaku Kaisei Kankei: Nihon Gaikō Bunsho, Bessatsu, Tsushō Jōyaku to Tsūshō Seisaku no Hensen. See also Itō Nobufumi, 'Nihon no Shin-Gaikō to Shidehara-san' [Japan's new diplomacy and Mr Shidehara], date unknown, in 'Shidehara Heiwa Bunko', Reel 13.

46 Moroi Tadakazu, ed., Moroi Rokurō Kun Tsuitō Ihō-roku [In remembrance of Moroi Rokurō] (Tokyo: Moroi Tadakazu, 1941), 8-14, 23-31, 47-48.

47 Shidehara, 'Washington Kaigi no Rimen-kan Sonota', 135.

48 Kurachi Tetsukichi, 'Kankoku Gappei no Keii' [The circumstances of the annexation of Korea], November 1939, in Hirose, Kindai Gaikō Kaikoroku, vol. 2, 249-85; Ishii, Gaikō Yoroku, 95.

49 'Kankoku Gappei nikansuru Sengen' [Declaration concerning the annexation of Korea], Kanpō, special edition, 29 August 1910; Kawashima Nobutarō, 'Shidehara Sōri heno Omoide'; Vice-Minister of Home Affairs Kubota Kiyochika to Shidehara, 25 December 1915, in Ministry of Foreign Affairs, Nihon Gaikö Bunsho, 1915, vol. 1, 381-88.

50 Asahi Shimbun, 11 March 1951.

51 Honda Kumatarō, Tamashii no Gaikō: Nichi-Ro Sensō niokeru Komura-Ko [Diplomacy of the spirit: Lord Komura and the Russo-Japanese War] (Tokyo: Chikura Shobō, 1941). Meanwhile, Teramoto Yasutoshi asserted:

Komura's imperialistic policies had the effect of further inflaming nationalistic sentiment in Qing-dynasty China. Conversely, Hayashi's policy of maintaining the status quo attracted domestic criticism from the elder statesmen [the genrō]. To put it differently, Japanese diplomacy after the Russo-Japanese War was trapped between demands of Japanese continental expansion on the one hand and the rise of Chinese nationalism on the other; it was unable to secure a stable foothold. This situation would similarly be reflected in later diplomatic troubles suffered under Foreign Ministers Tanaka and Shidehara.

See Teramoto Yasutoshi, Nichi-Ro Sensō Igo no Nihon Gaikō: Power Politics no Naka no Man-Kan Mondai [Japanese diplomacy after the Russo-Japanese War: The Manchuria-Korea Problem in the context of power politics] (Tokyo: Shinzansha, 1999), 533.

52 Mushanokōji, 'Shidehara-san no Omoide'. For Hirota, see also Hattori Ryūji, Hirota Kōki [Hirota Kōki] (Tokyo: Chūō Kōron Shinsha, 2008).

53 Shidehara, 'Gaikō Bunsho no Buntai, Kisōsha no Kokoroe narabini Shoshu no Keishiki', 90-91.

54 Ibid. See also Furuya Shigetsuna, 'Omoide Banashi Zai Sao Paolo' [Some recollections in Sao Paolo], Kasumigaseki-kai Kaihō, no. 240 (February 1966): 5.

55 'Gaimushō Gaikokujin Yatoiire Ikken (Fu-Keiyakusho) Bessatsu “Denison”-shi Kankei'; Shidehara Peace Foundation, Shidehara Kijūrō, 59.

56 One such example is related to diplomat Satō Naotake, who later became the foreign minister. At that time, Satō was still the third secretary at the Japanese embassy in Russia. In the summer of 1912, Satō returned to Japan for the first time. When he arrived via ferry at the Japanese town of Moji, he found a nation in mourning. Consequently, Satō was given the task of receiving members of the Spanish royal family. Sato attended the imperial funeral on 13 September at the Aoyama Parade Ground. At midnight, he solemnly watched the ox-drawn hearse depart. Returning to the Shiba Imperial Villa while reminiscing 'the great emperor's achievements', Sato received a copy of a newspaper extra, which reported that, when the casket was being transported, Nogi and his wife committed jijin (ritual suicide). Satō was stunned: 'I could not say a single word. It felt as though a strong force was pressing upon my heart'. After all, Satō had met with Nogi only a few days earlier. It was Nogi who appeared when Satō arrived at the entrance to the Shiba Imperial Villa. Nogi was 
responsible for entertaining Prince Arthur of Connaught, representative of the royal household of the United Kingdom. Given this diplomatic responsibility, Satō had the opportunity to see Nogi in person. See Satō, Kaiko 80 Nen, 103-05.

Nogi's suicide is also described in Nakano, Yoshizawa Kenkichi Jiden, 73. See also Tsukada Seiichi, ed., Nogi Taishö Jiseki [The achievements of General Nogi] (Tokyo: Privately Printed, 1916), 365-74; Office of Nogi Shrine, Nogi Maresuke Zenshü [The complete works of Nogi Maresuke], vol. 2 (Tokyo: Kokusho Publishing Association, 1994), 520.

57 Stanley Washburn, Nogi: A Man against the Background of a Great War (New York: Henry Holt and Company, 1913); reminiscences of Stanley Washburn, 1950, Oral History Research Office, Columbia University.

58 Shidehara Kijūrō, 'Jobun' [Introduction], 24 December 1923, in Stanley Washburn, Nogi [Nogi], trans. Meguro Masumi (Tokyo: Bunkōin, 1924), 1-5. The same text was reprinted in Stanley Washburn, Nogi [Nogi], trans. Meguro Masumi (Tokyo: Sōgensha, 1941); Stanley Washburn, Nogi Taishō to Nihonjin [General Nogi and the Japanese people], trans. Meguro Masumi (Tokyo: Kōdansha, 1980). As Washburn authored these two volumes, I refer to them collectively when speaking of Washburn and his opinions.

Further, Hamilton Wright and his wife were involved in the US response to the opium problem. For more information on this topic, see William Phillips diary, 29 January 1919, William Phillips Papers, Box 1, Houghton Library, Harvard University; Gotō Harumi, Ahen to Igirisu Teikoku: Kokusai Kisei no Takamari, 1906-43 [Opium and the British Empire: The tightening of international regulations, 1906-43] (Tokyo: Yamakawa Shuppansha, 2005), 30, 34, 36, 43, 61, 76.

59 Reminiscences of Washburn; Shidehara to Root, 6 August 1921, Elihu Root Papers, Box 139, Manuscript Division, Library of Congress; Root to Shidehara, 9 August 1921, Root Papers, Box 139.

60 Shidehara, 'Jobun', 1-5.

61 Ibid.

62 Meguro Masumi, 'Chogen' [Introduction], in Stanley Washburn, Nogi [Nogi], trans. Meguro Masumi (Tokyo: Bunkōin, 1924), 1, 10-13.

63 Meguro Masumi, 'Chogen' [Introduction], in Stanley Washburn, Nogi [Nogi], trans. Meguro Masumi (Tokyo: Bunkōin, 1924), 1, 10-13; Washburn to Hanihara, 27 November 1923, ibid., page numbers are not noted; Shidehara, 'Jobun', 3-4; reminiscences of Washburn; Shidehara to Root, 6 August 1921, Root Papers, Box 139.

64 Minister's Secretariat Personal Division, ed., Gaimushō Nenkan [Ministry of Foreign Affairs yearbook], 1913, 60. A work that summarises the developments leading up to passing of the 1913 Alien Land Law is Ministry of Foreign Affairs, ed., Tai-Bei Imin Mondai narabini Kashü Hai-Nichi Undo no Enkaku, Fu: Kashü Mondai Nichi-Bei Köshö Tenmatsu [The history of the US immigration problem and Californian anti-Japanese movement, supplement: An account of Japan-US negotiations concerning the California problem] (Tokyo: Ministry of Foreign Affairs, 1920). See also Minohara Toshihiro, 'Imin Mondai Kaiketsu eno Futatsu no Nichi-Bei Kōshō: 1913 Chinda-Bryan Kaidan to 1920 Shidehara-Morris Kaidan' [Two Japan-US negotiations for resolving the immigration problem: The 1913 Chinda-Bryan talks and the 1920 Shidehara-Morris talks], Kobe Högaku Zasshi 50, no. 1 (June 2000): 39-92.

65 Shidehara Kijūrō, 'Haku to Bryan-shi' [The Count and Mr Bryan], in Hakushaku Chinda Sutemi-Den [The biography of Count Chinda Sutemi], ed. Kikuchi Takenori (Tokyo: Kyōmeikaku, 1938), 138-40. See also Shidehara, Gaikö 50 Nen, 40-42, 316-18.

66 Bryan to Wilson, 2 October 1914, William Jennings Bryan Papers, Box 45, Manuscript Division, Library of Congress; Bryan to Wilson, 23 January 1915, Bryan Papers, Box 45.

67 James Bryce, The American Commonwealth, rev. ed., 2 vols (New York: Macmillan Company, 1911).

68 Edward Grey, Twenty-Five Years, 1892-1916, vol. 3 (London: Hodder and Stoughton Limited, 1935), 15-16, 24-25. 
69 Edward Price Bell, World Chancelleries: Sentiments, Ideas, and Arguments Expressed by Famous Occidental and Oriental Statesmen Looking to the Consolidation of the Psychological Bases of International Peace (Chicago: Chicago Daily News, 1926), 138-39; Shidehara, Gaikō 50 Nen, 48-51; Ōta Tamekichi, 'Shidehara-san wo Kataru' [Speaking about Mr Shidehara], 13 January 1953, in 'Shidehara Heiwa Bunko', Reel 13.

70 Shidehara, Gaiko 50 Nen, 51-53. In the same text, it is stated: 'It was certainly in the year 1919'. However, I suggest that this exchange actually took place in 1921.

71 James Bryce, International Relations: Eight Lectures Delivered in the United States in August, 1921 (New York: Macmillan Company, 1927), 126-29. Further, Bryce's final visit to the US is discussed in H. A. L. Fisher, James Bryce, vol. 2 (London: Macmillan Company, 1927), 280-87.

72 E. W. Edwards, 'China and Japan, 1911-1914', in British Foreign Policy under Sir Edward Grey, ed. F. H. Hinsley (Cambridge: Cambridge University Press, 1977), 380-81; Hattori, Higashi Asia Kokusai Kankyō no Hendō to Nihon Gaikō, 1918-1931, 23.

73 Shidehara, Gaikō 50 Nen, 254-56, 259-62.

In Mexico - where the incident took place - with the country falling into a state of civil strife, the more than 30-year rule of the dictator, Porfirio Diaz, ended. While Victoriano Huerta became the temporary president following a counter-revolutionary coup d'état, Grey knew that the Wilson administration was unfriendly towards Huerta. While he felt uncomfortable with US policies toward Mexico, Grey decided to turn a blind eye. In his opinion, there were no benefits to resisting US military intervention in Mexico. This was Grey-style realism, rather than a mere refusal to get involved. As it turned out, the civil strife continued until the early 1920s. See Grey, Twenty-Five Years, vol. 3, 26-29; Peter Calvert, The Mexican Revolution, 1910-1914: The Diplomacy of Anglo-American Conflict (Cambridge: Cambridge University Press, 1968), 163, 170, 187-88, 195, 200-01, 204, 209, 245-47; Lloyd C. Gardner, 'Woodrow Wilson and the Mexican Revolution', in Woodrow Wilson and a Revolutionary World, 1913-1921, ed. Arthur S. Link (Chapel Hill: University of North Carolina Press, 1982), 17-20.

Academic views on Wilson's diplomacy in the context of Mexico are also presented in Kusama Hidesaburō, Wilson no Kokusai Shakai Seisaku Kösō [Wilson's conception for international society policy] (Nagoya: Nagoya University Press, 1990), 58-67.

74 Reminiscences of William Phillips, 1951, Oral History Research Office, Columbia University; Keith Robbins, Sir Edward Grey: A Biography of Lord Grey of Fallodon (London: Cassell and Company Limited, 1971), 321-24; Yoshida Shigeru, Shidehara Kijūrō and Sato Naotake, 'Gaikō Jūō-dan' [Diplomatic free talk], Jiji Shinpo, 3 January 1950.

75 Foreign Minister Katō to Ambassador to the US Inoue, 3 July 1914, in 'Gaimushō Gaikokujin Yatoiire Ikken (Fu-Keiyakusho) Bessatsu "Denison”-shi Kankei’; Inoue to Katō, 9 March 1915, in 'Honpō Koyō Gaikokujin Kankei Zakken: Honshō no Bu' [Miscellaneous cases relating to the hiring of foreigners in Japan: Regarding this ministry], K.4.2.0.1-5, Diplomatic Archives of the Ministry of Foreign Affairs of Japan; Inoue to Foreign Minister Ōkuma, 16 September, ibid.; Shidehara, Gaikō 50 Nen, 248.

For further information on Baty, see Thomas Baty, Alone in Japan: The Reminiscences of an International Jurist Resident in Japan 1916-1954, ed. Hasegawa Motokichi (Tokyo: Maruzen, 1959); Ichimata Masao, 'Thomas Baty Hakase Seikyo' [On the passing of Dr Thomas Baty], Kokusaihō Gaikō Zasshi 53, nos 1, 2 (May 1954): 86-97; Ichimata Masao, Nihon no Kokusai Hōgaku wo Kizuita Hitobito, 172-76; Uchiyama Masakuma, 'Thomas Baty Hakase no Ronkō' [The merits of Thomas Baty], Kokusaihō Gaikō Zasshi 65, no. 6 (March 1967): 35-50; Ministry of Foreign Affairs Hundred-Year History Compilation Association, Gaimushō no 100 Nen, vol. 2, 1347-53; Murase Shinya, 'Twilight no Mukō ni: Higeki no Kokusaihō Gakusha Thomas Baty' [On the other side of twilight: The tragic scholar of international law, Thomas Baty] (1) (2) (3), Gaikō Forum, no. 177 (April 2003): 70-77, no. 178 (May 2003): 72-79, no. 179 (June 2003): 78-85; Peter Oblas, 'Naturalist Law and Japan's Legitimization of Empire in Manchuria: Thomas Baty and Japan's Ministry of Foreign Affairs', Diplomacy and Statecraft 15, no. 1 (2004): 35-55, doi.org/10.1080/09592290490438051; Martin Gornall, 'Dr Thomas Baty, 1869_ 1954: Legal Adviser to the Japanese Foreign Ministry, 1916-41', in Britain and Japan: Biographical Portraits, ed. Hugh Cortazzi, vol. 5 (Kent: Global Oriental, 2005), 431-42. 
76 Shidehara to Katō, 15 August 1914, in Ministry of Foreign Affairs, Nihon Gaikō Bunsho, 1914, vol. 3, 161; Inoue to Katō, 17 August, ibid., 165-66; Shidehara, Gaikō 50 Nen, 274.

77 Funakoshi Mitsunojō, 'Nichi-Doku Kaisen Tōji no Omoide: Furoku, Rakuyōshū (Zuihitsu)' [Memories of the commencement of the war between Japan and Germany: Supplement, fallen leaves collection (essays)], October 1938, in Hirose, Kindai Gaikö Kaikoroku, vol. 2, 305-06.

78 Ibid. We find the same observation in Shigemitsu Mamoru, Shigemitsu Mamoru Gaikō Kaisōroku [Shigemitsu Mamoru’s diplomatic memoirs] (Tokyo: Mainichi Shimbunsha, 1953), 21.

In his memoirs, Uchida Sadatsuchi stated that he took permission to send a coded telegram to the US chargé d'affaires in Sweden. This request was refused, meaning that the Brazilian minister's mediation was required instead. See Uchida Sadatsuchi, 'Zaikin Kakuchi niokeru Shuyō Jiken no Kaiko' [Recollections of major incidents during postings at numerous locations], January 1939, in Hirose, Kindai Gaikō Kaikoroku, vol. 1, 185-86. See also Hayashima Akira, ed., 'Uchida Sadatsuchi Nisshi' [The journal of Uchida Sadatsuchi], Shigaku Zasshi 88, no. 8 (August 1979): 75-90.

79 According to Funakoshi:

At the same time that our nation directly handed over its ultimatum to the German ambassador residing in Tokyo, the other related world powers were informed as to its contents. I cannot claim that this was good policy. Usually, when it comes to an ultimatum, it should be enough to deliver it to the respective nation and allow the massive significance of its contents to be understood.

See Funakoshi Mitsunojō, Nichi-Doku Kokkō Danzetsu Misshi [The secret history of the severing of diplomatic ties between Japan and Germany], ed. Sekino Naotsugu (Tokyo: Nittō Shoin, 1934), 101-03, 107-09, 123.

80 Horiuchi Tateki, Chügoku no Arashi no Naka de [In the storm that was China] (Tokyo: Kengensha, 1950), 37; Shidehara, Gaikō 50 Nen, 81.

81 Tani Masayuki, 'Holland Kōshi Jidai no Shidehara-san' [Mr Shidehara during his time as minister to the Netherlands], date unknown, in 'Shidehara Heiwa Bunko', Reel 18; Matsui Keishirō, Matsui Keishirō Jijoden [The autobiography of Matsui Keishirō] (Tokyo: Kankōsha, 1983), 81-82.

82 Shidehara Kijūrō, 'Chūgoku Kōshi Wang Rongbao to Watashi' [Chinese Minister Wang Rongbao and me], in Sekai no Kokoro to Sugata [The mind and form of the world], ed. Kijūrō Shidehara et al. (Tokyo: Fushichōsha, 1949), 3-7.

83 Shidehara, Gaikō 50 Nen, 248.

84 Nagai, 'Shidehara Danshaku no Omoide'.

85 Itō Hirokuni, vice-grand master of ceremonies in the Ministry of the Imperial Household, to Shidehara, 20 January 1916, in Ministry of Foreign Affairs, Nihon Gaikō Bunsho, 1916, vol. 1, 392; Takayama Kimimichi, chief of staff at the office of the Governor-General of Kwantung, to Shidehara, 16 September, ibid., 411-15.

For further details on the relationship between Japan and Russia during World War I, see Yoshimura Michio, Zōho Nihon to Russia [Japan and Russia], 2nd ed. (Tokyo: Nihon Keizai Hyōronsha, 1991), 169-318.

86 Shidehara to Malevich, 4 November 1915, in Ministry of Foreign Affairs, Nihon Gaikö Bunsho, 1915, vol. 3, part 2, 1185-88; Shidehara-Malevich talks, 6 January 1916, in Ministry of Foreign Affairs, Nihon Gaikō Bunsho, 1916, vol. 2, 1-2.

87 Yamada Ryūichi, vice-minister of war, to Shidehara, 6 April 1916, in Ministry of Foreign Affairs, Nihon Gaikō Bunsho, 1916, vol. 3, 402-06; Shidehara to Sugawara Michiyoshi, vice-minister of finance, 25 April 1916, ibid., 413-14; Shidehara to Sugawara, 10 June, ibid., 429-30; Shidehara to Sugawara, 27 June, ibid., 439; Shidehara to Shekine, counsellor to the Russian embassy in Japan, 25 August, ibid., 444; Shidehara-Shekine's talks, 25 September, ibid., 449-51; Shidehara to Krupinski, 6 October, ibid., 454-55; Shidehara to Shōda Kazue, vice-minister of finance, 10 October, ibid., 455-56; Shidehara to Shekine, 16 October, ibid., 456-57; Shidehara to Shōda, 19 October, ibid., 458-59; Shidehara to Shōda, ibid., 464-65; Yamada to Shidehara, 25 November, ibid., 471-75. 
88 Kamiyama Mitsunoshin, vice-minister of the Ministry of Agriculture and Commerce, to Shidehara, 9 May 1916, in Ministry of Foreign Affairs, Nihon Gaikō Bunsho, 1916, vol. 1, 253.

89 Shidehara to Shirani Takeshi, civil governor, office of the Governor-General of Kwantung, 3 August 1916, in Ministry of Foreign Affairs, Nihon Gaikō Bunsho, 1916, vol. 2, 898. For research into independence movements in Manchuria and Inner Mongolia, see Kurihara Ken, 'Daiichiji, Dainiji Man-Mō Dokuritsu Undō to Koike Gaimushō Seimukyoku-chō no Jinin' [The first and second Manchurian-Mongolian Independence movements and the resignation of Political Affairs Bureau Director-General Koike at the Ministry of Foreign Affairs], in Tai-Man-Mó Seisaku-shi no Ichimen [A partial history of policy on Manchuria and Mongolia], ed. Kurihara Ken (Tokyo: Harashobō, 1966), 139-61; Hatano Masaru, Man-Mō Dokuritsu Undō [The Manchurian and Mongolian independence movements] (Tokyo: PHP Institute, 2001).

90 Shidehara-Krupinski's talks, 12 August 1916, in Ministry of Foreign Affairs, Nihon Gaikō Bunsho, 1916, vol. 3, 601-03; Shidehara-Zhang Shizhao's talks, 14 October 1918, ibid., vol. 2, part 1, 49-50.

91 'Taigai Seisaku narabini Taido Kankei Zassan: Tai-Shina no Bu (Motono Daijin)' [Collection of miscellaneous issues regarding the foreign policy and position: Part relevant to China (Minister Motono), recorded by Matsumoto], 1.1.1.3-2-4, Diplomatic Archives of the Ministry of Foreign Affairs of Japan; Ministry of Foreign Affairs, Nihon Gaikō Nenpyō narabini Shuyō Bunsho, vol. 1, 42127; Ministry of Foreign Affairs, Nihon Gaikō Bunsho, 1917, vol. 2, 2-6; Obata Yūkichi Biography Publishing Association, ed., Obata Yükichi (Tokyo: Obata Yūkichi Biography Publishing Association, 1957), 190-204; Hatano Masaru, Kindai Higashi Asia no Seiji Hendō to Nihon no Gaikō [Political changes and Japanese diplomacy in modern East Asia] (Tokyo: Keio Tsūshin, 1995), 260-61.

A work that traces the orientation of the Political Affairs Bureau's First Division and minister to China Hayashi Gonsuke is Kumamoto Fumio, 'Daiichiji Taisen-ki niokeru Gaimushō no Tai-Chu Seisaku: "Keizai Teikei” kara “Bunka Teikei” eno Tenkan' [The Ministry of Foreign Affairs' policies regarding China during the period of World War I: The shift from 'economic partnership' to 'cultural partnership'], Shikyō, no. 45 (September 2002): 1-19.

92 Motono to Satō, ambassador to the US, 9 June 1917, in Ministry of Foreign Affairs, Nihon Gaikō Bunsho, 1917, vol. 3, 722-23; Wheeler to Shidehara, 11 June, ibid., 726-27.

93 Ministry of Foreign Affairs, Nihon Gaikō Nenpyō narabini Shuyō Bunsho, vol. 1, 439-40; Navy Vice-Minister Tochinai Sōjirō to Shidehara, 29 September 1917, in Ministry of Foreign Affairs, Nihon Gaikō Bunsho, 1917, vol. 3, 784; W. Reginald Wheeler, China and the World-War (New York: Macmillan Company, 1919), 124-25. For recent research on the agreement between Ishii and Lansing, see Takahara Shūsuke, Wilson Gaikō to Nihon [Wilson diplomacy and Japan] (Tokyo: Sōbunsha, 2006), 61-102.

94 Motono to Satō, 13 June 1917, in Ministry of Foreign Affairs, Nihon Gaikō Bunsho, 1917, vol. 3, 729-31; Satō to Motono, 15 June, ibid., 732; Sato to Lansing, 15 June 1917, in Papers Relating to the Foreign Relations of the United States [hereafter cited as FRUS], 1917, ed. Department of State (Washington: Government Printing Office, 1926), 71-72; Wheeler to Lansing, 18 June, ibid., 259; Lansing to Wheeler, 6 July, ibid., 260-62.

95 William Phillips diary, 30 July, 22 August, 8 October and 7 November 1917, Phillips Papers, Box 1 .

96 Morris to Lansing, 14 December 1917, in FRUS, 1918, Russia, ed. Department of State, vol. 2 (Washington: Government Printing Office, 1926), 7-8; Morris to Lansing, 7 January 1918, ibid., 20; from Morris to Lansing, 13 April, ibid., 121; J. Jules Jusserand (French ambassador to the US) to Lansing, 21 April, ibid., 128-29; Shidehara-Morris talks, 23 January 1918, in Ministry of Foreign Affairs, Nihon Gaikō Bunsho, 1918, vol. 1, 641; Shidehara-Green talks, 12 March, ibid., 701-04; Shidehara-Krupinski talks, 3 April, ibid., 513-16; Shidehara-Regnault's talks, 22 April, ibid., 785-86; Shidehara-Green talks, 19 April, ibid., 417-19.

97 William Phillips diary, 3 August 1918, Phillips Papers, Box 1; chief of staff of the Vladivostok Expeditionary Force, Lieutenant General Yuhi Mitsue, to Shidehara, 27 February 1919, in Ministry of Foreign Affairs, Nihon Gaikō Bunsho, 1919, vol. 1, 612-14. 
98 Shidehara-Green's talks, 27 September 1918, in Ministry of Foreign Affairs, Nihon Gaikō Bunsho, 1918, vol. 3, 409-11; Shidehara-Morris talks, 28 October, ibid., 429-32.

99 Ministry of Foreign Affairs, Nihon Gaikō Bunsho, 1918, vol. 3, 423-28; Hattori, Higashi Asia Kokusai Kankyō no Hendō to Nihon Gaikō, 1918-1931, 48-49.

100 Shidehara to vice-minister of war, Lieutenant General Yamanashi Hanzō, 4 August 1919, in Ministry of Foreign Affairs, Nihon Gaikō Bunsho, 1919, vol. 3, 1291-92; Shidehara, Gaikō 50 Nen, 95-97.

For further details on the Kolchak government and Katō Tsunetada, see Kageura Tsutomu, 'Katō Tsunetada', in Ehime no Senkaku-sha [Pioneers of Ehime], ed. Ehime Prefectural Education Committee, vol. 4 (Takamatsu: Ehime Prefectural Education Committee, 1966), 210-14; Hosoya Chihiro, Russia Kakumei to Nihon [The Russian revolution and Japan] (Tokyo: Harashobō, 1972), 85-192.

101 Shidehara-Miller talks, 7 August 1918, in Ministry of Foreign Affairs, Nihon Gaikö Bunsho, 1918, vol. 2, 231-32. For representative research on topics from this period, such as the New FourPower Consortium, see Mitani Taiichirō, Zōho Nihon Seitō Seiji no Keisei: Hara Takashi no Seiji Shido no Tenkai [The formation of party-based politics in Japan: The development of Hara Takashi's political leadership], 2nd ed. (Tokyo: University of Tokyo Press, 1995), 321-52. For my own views on this matter, see Hattori, Higashi Asia Kokusai Kankyō no Hendō to Nihon Gaikō, 1918-1931, 4-6, $20-34$.

102 Mushanokōji, 'Shidehara-san no Omoide'. I have covered the Paris Peace Conference in more detail in Hattori, Higashi Asia Kokusai Kankyō no Hendō to Nihon Gaikō, 1918-1931, 34-46. Therefore, I will treat the topic relatively lightly here.

103 Robert Lansing, The Peace Negotiations: A Personal Narrative (Boston: Houghton Mifflin Company, 1921), 243-67.

104 Shidehara to Lansing, 26 March 1921, in 'Makino Nobuaki Kankei Bunsho' [Documents relating to Makino Nobuaki], Correspondence Department, vol. 28, Modern Japanese Political History Materials Room, National Diet Library; Shidehara, Gaikō 50 Nen, 318-19.

105 Shidehara himself provided details on the feud with Itō Miyoji in the Extraordinary Foreign Diplomacy Investigation Committee in Shidehara Kijūrō (speaking), Kiyosawa Kiyoshi (transcribing), 'Inin-chi Tōchi-ryo Tōchi Keishiki' [The form of mandated governance for lands and territories], date unknown, in 'Shidehara Heiwa Bunko', Reel 18.

106 Katō Takaaki, 'Fusanka no Riyū' [Reason for non-participation], Seinen 5, no. 7 (June 1917): 37-42; 'Katō-shi no Benkai' [The self-justification of Viscount Katō], Seiyu, no. 208 (July 1917): 45-49; Yokoyama Katsutarō and Higuchi Hideo, eds, Kenseikai-shi [A history of the Kenseikai], vol. 1 (Tokyo: Harashobō, 1985), 70-73.

For recent studies of Katō Takaaki, see Sakurai Ryōjū, 'Katō Takaaki to Ei-Bei-Chu Sangoku Kankei' [Katō Takaaki and the tri-nation relationship between the UK, the US and China], in Taishō-ki Nihon no America Ninshiki [Japan's perception of the US in the Taishō era], ed. Hasegawa Yūichi (Tokyo: Keio University Press, 2001), 79-121; Naraoka Sōchi, 'Katō Takaaki no Seiji Shidō to Kenseikai no Sōritsu: 1915-1919' [Katō Takaaki's political leadership and the founding of the Kenseikai: 19151919], (1) (2), Hōgaku Ronsō 151, no. 2 (May 2002): 112-37, 152, no. 1 (October 2002): 114-35; Naraoka Sōchi, 'Katō Takaaki Naikaku no Seiji Katei: Katō Takaaki no Seiji Shidō to Ni-Daiseitō-sei no Seiritsu' [The political process of the Katō Takaaki cabinet: Katō Takaaki's political leadership and the formation of the two-major-party system], (1) (2), Hōgaku Ronsō 152, no. 3 (December 2002): 64-87, 153, no. 1 (April 2003): 122-43.

107 Hara, Hara Takashi Nikki, vol. 4, 68, 126, 140.

108 Shidehara to Uchida, 20 November 1919, in Ministry of Foreign Affairs, Nihon Gaikö Bunsho, 1919, vol. 3, part 1, 402-06, 771-72.

109 Ishii Itarō, Gaikōkan no Isshō [The life of a diplomat] (Tokyo: Chūōkōronsha, 1986), 70-71, 80-81. See also Hirota Kōki Biography Publishing Association, Hirota Kōki (Tokyo: Ashishobō, 1992), 61. 
110 Ishii Itarō, 'Shidehara-Dan no Omoide' [Memories of Baron Shidehara], date unknown, in 'Shidehara Heiwa Bunko', Reel 13; Shidehara, Gaikō 50 Nen, 281-84.

111 Shidehara to Uchida, 24 October 1919, in Ministry of Foreign Affairs, Nihon Gaikö Bunsho, 1919, vol. 1, 693-94; Vladivostok Expeditionary Force Chief of Staff, Lieutenant General Inagaki Saburō, to Yamanashi, 8 January 1920, in Ministry of Foreign Affairs, Nihon Gaikö Bunsho, 1920, vol. 1, part 2, 837; Shidehara to Uchida, 11 January, ibid., 840-48; Hara, Hara Takashi Nikki, vol. 5, 199; Shidehara, Gaikō 50 Nen, 97-99.

112 Reminiscences of DeWitt Clinton Poole, 1952, Oral History Research Office, Columbia University. For further details on the issue of the removal of troops from Siberia, see Takahara, Wilson Gaikō to Nihon, 118-68.

113 For research related to Yap Island, see Paul H. Clyde, Japan's Pacific Mandate (New York: Macmillan Company, 1935), 45-62; Hirama Yōichi, Daiichiji Sekai Taisen to Nihon Kaigun: Gaikō to Gunji to no Rensetsu [World War I and the Japanese navy: The connection between diplomacy and military] (Tokyo: Keiō University Press, 1998), 131-45; Inada Shinjō, 'Nihon Kaigun no Micronesia Senryō to Yap-tō Mondai' [The occupation of Micronesia by the Japanese navy and the problem of Yap Island], Waseda Daigaku Daigakuin Hoken Ronshü, no. 90 (June 1999): 103-22.

114 Government Office of the South Sea Islands, Nanyōchö Shisei 10 Nenshi [A 10-year history of administration by the Government Office of the South Sea Islands] (Tokyo: Government Office of the South Sea Islands' Director General's Secretariat, 1932), 65-73.

115 Shidehara to Tochinai, 14 August 1919, in Ministry of Foreign Affairs, Nihon Gaikō Bunsho, 1919, vol. 3, part 1, 411; Tochinai to Vice-Minister for Foreign Affairs Hanihara Masanao, 15 September , ibid., 415-16; Provisional Micronesia Defense Corps, 'Nanyōgun-tō: Tō-sei Chōsa Hōkoku' [Micronesia: Island status investigative report], 1 October 1920, in Gaichi Kokusei Chōsa Hōkoku, Dai 6 Shū: Nanyō Guntō Tösei Chōsa Hökoku [Reports on the census of foreign lands, no. 6: Reports on the island census of the South Seas Islands], ed. Onuma Yoshishige, vol. 1 (Tokyo: Bunseishoin, 1999), 1-15.

116 Shidehara to Uchida, 8 October 1920, in Ministry of Foreign Affairs, Nihon Gaikō Bunsho, 1920, vol. 3, part 1, 469-71; Ishii Kikujirō, ambassador to France, to Uchida, 23 February 1921, ibid., vol. 3, part 1, 268-72. Minutes of various meetings are included in Davis, Norman H. Papers, Box 30, Manuscript Division, Library of Congress. Also see memorandum by Davis of a conversation with Shidehara, 28 February 1921, Davis Papers, Box 9.

117 Shidehara to Uchida, 2 May 1921, in Ministry of Foreign Affairs, Nihon Gaikō Bunsho, 1921, vol. 3, part 1, 359-63; Shidehara to Uchida, 20 August, ibid., 384-89; Hughes to Shidehara, 15 September 1921, in FRUS, 1921, ed. Department of State, vol. 2 (Washington: Government Printing Office, 1945), 297-99.

118 Shidehara to Uchida, 11 February 1922, in Ministry of Foreign Affairs, Nihon Gaikō Bunsho, 1922, vol. 3, 378-87; convention between the US and Japan, 11 February 1922, in FRUS, 1922, ed. Department of State, vol. 2 (Washington: Government Printing Office, 1945), 600-04.

119 Government Office of the South Sea Islands, Nanyōchö Shissei Jyünen-shi [A 10-year history of administration by the Government Office of the South Sea Islands] (Tokyo: Government Office of the South Sea Islands' Director General's Secretariat, 1932), 38-53; Shidehara, Gaikō 50 Nen, 79-80, $143-44$.

120 Memorandum by Long of a conversation with Shidehara, 13 December 1919, Breckinridge Long Papers, Box 183, Manuscript Division, Library of Congress; Lansing to Shidehara, 13 December 1919, Long Papers, Box 183; Polk to MacMurray, 20 February 1920, Frank Lyon Polk Papers, Box 28, Sterling Memorial Library, Yale University.

121 Shidehara to Uchida, 24 November 1919, in Ministry of Foreign Affairs, Nihon Gaikō Bunsho, 1919, vol. 1, 81-83; Uchida to Shidehara, 6 December, ibid., 101-02. See also Minohara, 'Imin Mondai Kaiketsu eno Futatsu no Nichi-Bei Kōshō', 62-77. 
122 Ministry of Foreign Affairs, ed., Nihon Gaikō Bunsho: Tai-Bei Imin Mondai Keika Gaiyō [Documents on Japanese foreign policy: Overview of process of the US immigration problem] (Tokyo: Ministry of Foreign Affairs, 1972), 623-71; Ministry of Foreign Affairs, ed., Nihon Gaiko Bunsho: Tai-Bei Imin Mondai Keika Gaiyo Fuzokusho [Documents on Japanese foreign policy: Overview of process of the US immigration problem supplementary documents] (Tokyo: Ministry of Foreign Affairs, 1973), 561-679.

123 Speech by Morris before the Japan Society, 15 December 1920, Roland S. Morris Papers, Box 13, Manuscript Division, Library of Congress.

124 Hara, Hara Takashi Nikki, vol. 5, 339; Iimori Akiko and Hatano Masaru, 'Taishō 10 Nen Kōtaishi Hirohito: Maboroshi no Hōbei' [Crown Prince Hirohito's abandoned visit to the US in the 10th year of Taishō], Ningen Kagaku Ronkyū, no. 3 (February 1995): 233-43; Hatano Masaru, Hirohito Kötaishi Europe Gaiyü-ki [Record of Crown Prince Hirohito's visit to Europe] (Tokyo: Sōshisha, 1998), 57-62.

125 Shidehara to Uchida, 31 January 1921, in 'Kōtaishi Hirohito Shinnō Heika Gotoō Ikken' [The matter of His Imperial Highness the Crown Prince Hirohito's visit to Europe], L.1.3.0.6, Diplomatic Archives of the Ministry of Foreign Affairs of Japan; Hara, Hara Takashi Nikki, vol. 5, 366. Later, while dining with the emperor and prime minister, Shidehara also spoke of the 'impoliteness' of Americans. See Ōta Kenichi, Okazaki Katsuki, Sakamoto Noboru and Nanba Toshinari, eds, Tsugita Daisaburō Nikki [The diary of Tsugita Daisaburō] (Okayama: Sanyō Shimbunsha, 1991), 93.

126 Shidehara, Gaikō 50 Nen, 72. Regarding the Washington Naval Conference, see Asada Sadao, Ryö-Taisen-kan no Nichi-Bei Kankei: Kaigun to Seisaku Kettei Katei [Japanese-American relations between the two world wars: The navy and the process of policy decision-making] (Tokyo: University of Tokyo Press, 1993), 51-148; Hattori, Higashi Asia Kokusai Kankyō no Hendō to Nihon Gaikō, 1918-1931, 89-112; Hattori, 'The Washington Conference and East Asia, 1921-1922', Sögō Seisaku Kenkyū, no. 29 (March 2021): 1-20.

127 Shidehara to Uchida, 28 August 1921, in Nihon Gaikō Bunsho: Washington Kaigi [Documents on Japanese foreign policy: The Washington Naval Conference], ed. Ministry of Foreign Affairs, vol. 1 (Tokyo: Ministry of Foreign Affairs, 1977), 146-47; Shidehara to Uchida, 15 September, ibid., 160-61; Hara, Hara Takashi Nikki, vol. 5, 415.

128 Department of State, ed., FRUS, 1899 (Washington: Government Printing Office, 1945), 131-33; Department of State, FRUS, 1900, 299. For classic studies of this topic, see A. Whitney Griswold, The Far Eastern Policy of the United States (New York: Harcourt, Brace and Company, 1938), 36-86; Iriye Akira, Pacific Estrangement: Japanese and American Expansion, 1897-1911 (Cambridge: Harvard University Press, 1972), 66.

129 Charles E. Hughes, 'Some Aspects of Our Foreign Policy', 29-33, 29 December 1922, 500, A4/508, Record Group 59, National Archives.

130 Shidehara, 'Washington Kaigi no Rimen-kan Sonota', 125-26.

131 Shidehara Kijūrō (speaking), Kiyosawa Kiyoshi (transcribing), 'Washington Kaigi no Hanashi (zoku)' [About the Washington Naval Conference (continued)], 1944, in 'Shidehara Heiwa Bunko', Reel 18.

132 Japanese delegation to Uchida, 16 December 1921, in Nihon Gaikö Bunsho: Washington Kaigi, ed. Ministry of Foreign Affairs, vol. 2 (Tokyo: Ministry of Foreign Affairs, 1978), 386-88; Japanese delegation to Uchida, 5 February 1922, ibid., 414-18; Hattori, Higashi Asia Kokusai Kankyō no Hendō to Nihon Gaikō, 1918-1931, 97-99, 255-63.

133 Shidehara, Gaikō 50 Nen, 84, 88; Hattori, Higashi Asia Kokusai Kankyō no Hendō to Nihon Gaikō, 1918-1931, 99-102.

134 Johnson was also bitter about how the US and Japan opposed each other in the conference on Yap Island and Chinese communication services. The German-controlled Yap-Shanghai submarine cable had been transferred to Japan. From Johnson's perspective, it was impermissible for Japan to have monopolised control over wireless communication in China. Beginning before the conference, the US had supported the American Federal Company, attempting to enter the Chinese wireless 
communications market. However, the issue of Chinese wireless communication was left unresolved at the Washington Naval Conference, leaving the opposition between Japan and the US on this front to linger. It was also typical of Johnson to evaluate the Nine-Power Treaty from the perspective of pursuing an open door ideal in China. According to Johnson, Japan unwillingly followed the US's lead in this area. Further, Johnson worried a great deal about how to secure the removal of Japanese soldiers from Siberia. See reminiscences of Nelson Trusler Johnson, 1954, Oral History Research Office, Columbia University.

For details on Japanese and US opposition regarding communication services in China, see Sunaga Noritake, 'Chūgoku no Tsushin Shihai to Nichi-Bei Kankei: Mitsui-Sōkyō Mudendai Shakkan to Federal Shakkan wo Megutte' [Control of Chinese communications and the Japan-US relationship: The Mitsui-Shuanqiao wireless station loan and the federal loan], Keizai Shüshi 60, no. 4 (January 1991): 157-87; Higuchi Hidemi, Nihon Kaigun kara Mita Nicchū Kankei-shi Kenkyū [A study of the history of the Sino-Japanese relationship from the perspective of the Japanese navy] (Tokyo: Fuyō Shobō Shuppan, 2002), 87-88; Hattori Ryūji, ed., Manshū Jihen to Shigemitsu Chūka Kōshi Hōkokusho: Gaimushō Kiroku 'Shina no Taigai Seisaku Kankei Zassan "Kakumei Gaikō" niyosete [The Manchurian incident and the report by minister to China Shigemitsu: A Ministry of Foreign Affairs record 'miscellaneous collection relating to the Chinese foreign policy "revolutionary diplomacy"'] (Tokyo: Nihon Tosho Center, 2002), 171-72.

135 Williams to Hughes, 24 September 1921, Edward Thomas Williams Papers, Box 1, Bancroft Library, University of California at Berkeley; Williams to MacMurray, 5 December 1921, Williams Papers, Box 1.

136 Williams diary, 22-23 July, 23-24 August, 13 September and 24 October 1921, Williams Papers, Box 3; Shidehara to Uchida, 4 August 1921, in 'Washington Kaigi Ikken: Keihatsu Sonota Senden Zakken' [Washington conference: Enlightenment and other miscellaneous publicities], 2.4.3.55, Diplomatic Archives of the Ministry of Foreign Affairs of Japan. See Hu Shizhang, Stanley K. Hornbeck and the Open Door Policy, 1919-1937 (Westport: Greenwood Press, 1995), 52.

137 Williams to MacMurray, 19 January 1922, Williams Papers, Box 1; Williams to Hughes, 24 January 1922, Williams Papers, Box 1; Williams to MacMurray, 7 January 1922, Williams Papers, Box 1 .

138 Memorandum by the office of Hughes for the interview with Shidehara, 4 January 1922, Charles Evans Hughes Papers, Reel 126, Manuscript Division, Library of Congress.

139 Balfour to Lloyd George, 11 November 1921, in Documents on British Foreign Policy 1919-1939 [hereafter cited as DBFP], ed. Rohan Butler and J. P. T. Bury, first series, vol. 14 (London: Her Majesty's Stationery Office, 1966), 466-70; Balfour to Lloyd George, 24 November, ibid., 50511; Balfour to George N. Curzon, 29 November, ibid., 522-23; Japanese delegation to Uchida, 24 November 1921, in Ministry of Foreign Affairs, Nihon Gaikō Bunsho: Washington Kaigi, vol. 1, 547-50; Japanese delegation to Uchida, 29 November, ibid., 552-55; Japanese delegation to Uchida, 1 December, ibid., 564-66.

140 For example, according to Okazaki Hisahiko, Shidehara Kijūrō to Sono Jidai [Shidehara Kijūrō and his Era] (Tokyo: PHP Institute, 2000), 194-97, the Japanese government proceeded with a policy to 'secure the existence of the Anglo-Japanese Alliance by clarifying that it did not apply to the United States'. However:

Shidehara, based on his own individual judgment, threw away the asset known as the Anglo-Japanese Alliance, which had been carefully built up over 20 years. He did this without proper discussion with the Japanese government or a clarification to Japan of the significance of what the alliance's termination would mean.

Further, according to Okazaki, what Shidehara should have done was present the Balfour proposal to the US as a proposal for Japanese-British cooperation:

If the U.S. were to have rejected this proposal, then the U.K. would have to decide what is to be done. However, as a nation which prides itself on acting in a gentlemanly manner, it would be difficult for them to come forward with the proposal to end a 20 -year alliance ... 
For Shidehara to end an alliance even when the U.K. had not made the offer itself, to put it bluntly, constituted a violation of orders ... Naturally, he could be criticized for attempting to be too clever with his application of diplomatic technique.

During a symposium, Mr Okazaki also stated: 'If Shidehara had attempted to maintain the alliance, then the alliance would have continued'. See Okazaki Hisahiko et al., 'Shidehara Gaiko no Zasetsu' [The failure of Shidehara diplomacy]', Shokun 35, no. 2 (February 2003): 241. Similar statements can also be found in Okazaki Hisahiko, Nihon Gaikō no Jōhō Senryaku [The information strategy of Japanese diplomacy] (Tokyo: PHP Institute, 2003), 28-35; Okazaki Hisahiko, Dokode Nihonjin no Rekishi-kan ha Yugandanoka [Where did the Japanese view of history become distorted?] (Tokyo: Kairyūsha, 2003), 139-43.

141 Uchida to Hara, 13 October 1921, in Ministry of Foreign Affairs, Nihon Gaikō Bunsho: Washington Kaigi, vol. 1, 181-218.

142 Shidehara, 'Washington Kaigi no Rimen-kan Sonota', 118-19. See also see Shidehara, Gaikō 50 Nen, 61-63.

143 Shidehara, 'Washington Kaigi no Rimen-kan Sonota', 118-19. See also see Shidehara, Gaiko 50 Nen, 61-63.

144 Shidehara, 'Washington Kaigi no Rimen-kan Sonota', 118-22. See also see Shidehara, Gaikō 50 Nen, 63-66.

145 Shidehara, 'Washington Kaigi no Rimen-kan Sonota', 118-22. See also see Shidehara, Gaiko 50 Nen, 63-66.

146 Shidehara, 'Washington Kaigi no Rimen-kan Sonota', 118-19. See also see Shidehara, Gaikō 50 Nen, 63-66.

147 Curzon to Auckland C. Geddes (British ambassador to the US), 29 June 1921, in Butler and Bury, DBFP, first series, vol. 14, 316-18; Geddes to Curzon, 6 July, ibid., 326; Curzon to Geddes, 9 July, ibid., 336-38; memorandum of a conversation between Hugh and Geddes, 23 June 1921, in Department of State, FRUS, 1921, vol. 2, 314-16.

148 Ishii, Gaikōkan no Isshō, 69.

149 Herbert O. Yardley, The American Black Chamber (New York: Blue Ribbon Books, 1931), 250-317; Herbert O. Yardley, Black Chamber: Beikoku ha Ikanishite Gaikō Mitsuden wo Nusundaka? [The black chamber: How did the US steal the secret diplomatic telegrams?], trans. Osaka Mainichi Shimbun (Osaka: Osaka Mainichi Shimbun, 1931), 303-90; Shidehara, Gaikō 50 Nen, 77.

150 Kurusu Saburō, Hōmatsu no 35 Nen [A fleeting 35 years] (Tokyo: Chūōkōronsha, 1986), 218-19.

151 Eliot to Curzon, 13 January 1922, in Butler and Bury, DBFP, first series, vol. 14, 606-08; Francis Stewart Gilderoy Piggott, Broken Thread: An Autobiography (Aldershot: Gale \& Polden Limited, 1950), 144-45; reminiscences of Sir George Sansom, 1957, Oral History Research Office, Columbia University; Wellesley, Victor, 'Anglo-Japanese Alliance and Our Future Policy in the Far East', 1 September 1920, F 2200/199/23, FO 371/5361, National Archives; Hattori, Higashi Asia Kokusai Kankyō no Hendō to Nihon Gaikō, 1918-1931, 44-45.

152 Reminiscences of Eugene H. Dooman, 1962, Oral History Research Office, Columbia University.

153 Balfour to Curzon, 9 December 1921, in Butler and Bury, DBFP, first series, vol. 14, 546-47. See also Balfour to Curzon, 25 December, ibid., 576-77; note of a conversation between Balfour and Kato, 5 January 1922, ibid., 585-87; Uchida to Japanese delegation, 17 December 1921, in Ministry of Foreign Affairs, Nihon Gaiko Bunsho: Washington Kaigi, vol. 1, 616-18; Shidehara to Uchida, 21 February 1922, ibid., 677-80; Shidehara, Gaikö 50 Nen, 67-68.

154 Baba Tsunego, Gendai Jinbutsu Hyōron [A review of contemporary figures] (Tokyo: Chuōkōronsha, 1930), 275.

155 Ishii, Gaikō Yoroku, 417.

156 For details on how Saitō attempted to sway opinion in the US, see Sawada, Zuikan, Zuihitsu, $69-74$. 
157 Shidehara, 'Washington Kaigi no Rimen-kan Sonota', 106.

158 Shidehara Kijūro, 'A Frank Official Statement for Japan', Current History, vol. 15, no. 3 (1921): 394-97; Shidehara to Lamont, 6 December 1921, Thomas William Lamont Papers, Box 186, Barker Library, Harvard University. The same journal also included an essay by Chinese plenipotentiary Shi Zhaoji (Alfred Sao-ke Sze). See Sze, Sao-Ke Alfred, 'China at the World Council', Current History, vol. 15, no. 3 (1921): 397-99.

Moore later assumed a role at the head office of the Japanese Ministry for Foreign Affairs in March 1922. See Foreign Minister Uchida to Inoue Katsunosuke, Grand Master of Ceremonies, 3 November 1922, in 'Honpō Koyō Gaikokujin Kankei Zakken'. Also see Frederick Moore, With Japan's Leaders: An Intimate Record of 14 Years as Counsellor to the Japanese Government, Ending December 7, 1941 (New York: Charles Scribner's Sons, 1942), 5, 9, 57-60, doi.org/10.1086/236683; Matsumura, 'Washington Kaigi to Nihon no Kōhō Gaikō', 47-76.

159 Uchida to Shidehara, 28 November 1921, in Ministry of Foreign Affairs, Nihon Gaikō Bunsho: Washington Kaigi, vol. 1, 550-51; Uchida to Shidehara, 29 November, ibid., 562-63; Uchida to Shidehara, 17 December, ibid., 616; Jiji Shinpō, 28 November 1921; Itō Masanori, Shimbun 50 Nenshi [A 50-year history of newspapers] (Tokyo: Masushobō, 1943), 256-57; Shidehara, Gaikō 50 Nen, 65, 256-59; Ishii, Gaikökan no Isshō, 102-04.

160 Shidehara to Uchida, 17 August 1921, in 'Washington Kaigi Ikken'.

161 Tsutsui Kiyoshi, 'Saigo no Gaikō' [The final diplomacy], Kasumigaseki-kai Kaihō, no. 305 (March 1971): 12; Lamont to Inoue, 10 October 1923, in 'Inoue Junnosuke Kankei Bunsho' [Documents relating to Inoue Junnosuke], Reels 7-11, Center for Modern Japanese Legal and Political Documents, the Faculty of Law, the University of Tokyo.

162 Shidehara, Gaikō 50 Nen, 248, 306-07.

163 Ishii, 'Shidehara-Dan no Omoide'.

164 Frank Lyon Polk diary, 2 March 1920, Polk Papers, Reel 3. This topic will be further covered in Chapter 2.

165 Kitaoka Shinichi, '21-kajō Saikō: Nichi-Bei Gaikō no Sōgo Sayō' [Reconsidering the 21 Demands: The mutual interaction of Japan-US diplomacy], Nenpyö Kindai Nihon Kenkyü, no. 7 (October 1985): 119-50; Takahara, Wilson Gaikö to Nihon, 31-60. 
This text is taken from Japan at War and Peace: Shidehara Kijürō and the Making of Modern Diplomacy, by Ryuji Hattori, published 2021 by ANU Press, The Australian National University, Canberra, Australia.

doi.org/10.22459/JWP.2021.02 